UNIVERSIDADE DE SÃO PAULO

FACULDADE DE FILOSOFIA, LETRAS E CIÊNCIAS HUMANAS DEPARTAMENTO DE LETRAS CLÁSSICAS E VERNÁCULAS PROGRAMA DE PÓS-GRADUAÇÃO EM LITERATURA PORTUGUESA

SÔNIA MARIA DE ARAÚJO CINTRA

Relações espaciotemporais na obra poética de Cesário Verde:

fragmentação e busca de totalidade

São Paulo 
UNIVERSIDADE DE SÃO PAULO

FACULDADE DE FILOSOFIA, LETRAS E CIÊNCIAS HUMANAS DEPARTAMENTO DE LETRAS CLÁSSICAS E VERNÁCULAS PROGRAMA DE PÓS-GRADUAÇÃO EM LITERATURA PORTUGUESA

Relações espaciotemporais na obra poética de Cesário Verde:

fragmentação e busca de totalidade

Sônia Maria de Araújo Cintra

Dissertação apresentada ao Programa de PósGraduação em Literatura Portuguesa do Departamento de Letras Clássicas e Vernáculas da Faculdade de Filosofia, Letras e Ciências Humanas da Universidade de São Paulo, para a obtenção do título de Mestre em Letras.

Orientadora: Profa. Dra. Raquel de Sousa Ribeiro

São Paulo 


\section{Relações espaciotemporais na obra poética de Cesário Verde: fragmentação e busca de totalidade}

Dissertação apresentada ao Programa de PósGraduação em Literatura Portuguesa do Departamento de Letras Clássicas e Vernáculas da Faculdade de Filosofia, Letras e Ciências Humanas da Universidade de São Paulo, para obtenção do título de Mestre em Letras.

Aprovada em

\section{Banca Examinadora}

\section{MEMBROS TITULARES}

Orientadora: Profa. Dra. Raquel de Sousa Ribeiro

Departamento de Letras Clássicas e Vernáculas - FFLCH/USP

Interno: Profa. Dra. Lílian Lopondo

Departamento de Letras Clássicas e Vernáculas - FFLCH/USP

Externo: Prof. Dr. José Renato Nalini

Professor Titular de Ética - DIREITO/FAAP

\section{MEMBROS SUPLENTES}

Interno: Profa. Dra. Guaraciaba Micheletti

Departamento de Letras Clássicas e Vernáculas - FFLCH/USP

Interno: Profa. Dra. Maria Adélia Aparecida de Souza

Departamento de Geografia Humana - FFLCH/USP

Externo: Prof. Dr. Manoel Francisco Guaranha

Departamento de Letras Clássicas e Vernáculas - UNICSUL 


\section{DEDICATÓRIA}

Dedicamos esta dissertação aos leitores e admiradores, estudiosos e pesquisadores da obra poética de Cesário Verde.

Ao Poeta, in memoriam 


\section{AGRADECIMENTOS}

Agradecemos, em especial,

à Profa. Dra. Raquel de Sousa Ribeiro, porque sempre nos orientou com muita dedicação e empenho;

ao Prof. Dr. Massaud Moisés, porque despertou em nós o interesse pela poesia cesariana;

às Profas. Dras. Lilian Lopondo e Guaraciaba Micheletti, porque abordaram questões instigantes durante o exame para qualificação;

aos Profs. Drs. Maria Adélia Aparecida de Souza, Carlos Augusto de Figueiredo Monteiro e Michel Rochefort, porque nos incentivaram e esclareceram a compreensão do espaço geográfico;

aos Profs. Joaquina Elisa Ribeiro Sampaio de Melo Serrano e Carlos de Aquino Pereira, porque nos iniciaram nos estudos literários, na Pontifícia Universidade Católica de Campinas;

à Prof. Dra. Claudia Amigo Pino e àqueles professores e teóricos que, ao longo da existência, contribuíram para nossa formação humanista e elaboração deste trabalho;

à Universidade de São Paulo, funcionários e colegas de cursos e seminários, porque nos ajudaram no transcorrer deste percurso;

àqueles familiares, amigos, colegas de magistério, alunos que fortaleceram a busca e partilha deste conhecimento; dentre eles, Eneida Ramalho de Paula, Ivanira de Souza Lima Dadalt e Solange Campos Bocchino;

a meus avós Carlos e Luzia, Mercedes e Herculano; pais, Maria e Roberto; a Sandra e Fernando, filhos; e ao Araken, companheiro de caminho, sem os quais não teríamos chegado até aqui, com gratidão e afeto. 


\section{RESUMO}

\section{Relações espaciotemporais na obra poética de Cesário Verde: fragmentação e busca de totalidade}

A partir da análise das relações espaciotemporais no poema $O$ Sentimento dum Ocidental queremos demonstrar que a obra poética de Cesário Verde se constitui num incessante processo de fragmentação e busca de totalidade. Sua coesão mostra, de modo sintético, uma visão de mundo e constitui um sumário da problemática cesariana, não apenas dos poemas dessa fase ou ciclo específico, mas do conjunto de sua poesia. Essas duas funções, a coesão e a problemática, revelam a prevalência da unidade poética de Cesário, a despeito de sua aparente diversidade temática e originalidade de estilo o qual apresenta traços impressionistas. Consideradas as diferenças de contexto, o processo acima mencionado reflete a crise que vivemos nos dias atuais. Embora a crise contemporânea se apresente de modo diferente, podemos perceber algumas de suas raízes já expressas nos versos de Cesário, o que admite uma aproximação entre Literatura e Geografia.

Palavras-chave: poesia, sujeito, espaço, tempo, linguagem. 


\begin{abstract}
Space-time relations in the poetic work of Cesário Verde: fragmentation and search for totality
\end{abstract}

From the analysis of the space-time relations en the poem $O$ Sentimento dum Ocidental we want to demonstrate that the poetic work of Cesário Verde is constructed by an incessant process of fragmentation and search for totality. Its cohesion shows, in a synthetic way, a world view and it constitutes a summary of the cesarian problematic, considering not only the poems of this phase or specific cycle, but the whole of his poetry. These two functions, cohesion and problematic, reveal the prevalence of the poetic unity of Cesário, despite its apparent thematic diversity and originality of style which presents some impressionist traces. Taking into consideration the differences of context, the process above mentioned reflects the crisis we live nowadays. Even though the contemporary crisis shows itself in a different manner, we can perceive some of its roots already expressed in Cesário's verses, what admits an approaching between Literature and Geography

Key words: poetry, subject, space, time, language. 


\section{LISTA DE ANEXOS}

ANEXO A - Poema O Sentimento dum Ocidental, Cesário Verde ------------------p. 10

ANEXO B - Poema Em Lisboa com Cesário Verde, Eugénio de Andrade --------- p. 34

ANEXO C - Poema Cesário Verde, Sophia de M. B. Andersen --------------------- p. 34

ANEXO D - Poema Improviso, Manuel Bandeira---------------------------------- p. 34

ANEXO E - Poema $O$ sim contra o sim, João Cabral de Melo Neto-------------------p. 34

ANEXO F - Sumário da produção poética de Cesário Verde, Joel Serão-----------p. 36

ANEXO G - Poema Ficções de Interlúdio/ III, Alberto Caeiro-----------------------p. 125

\section{LISTA DE FIGURAS}

FIGURA 1 - Reprodução gráfica do "Retrato de Cesário Verde”, Columbano--------p. 28

FIGURA 2 - Reprodução gráfica da Capa de "O Livro de Cesário Verde” ------------p. 29

FIGURA 3 - Reprodução gráfica da pintura "O Chora”, Rafael Bordalo Pinheiro----p. 40

FIGURA 4 - Reprodução gráfica da demarcação da área do incêndio em Lisboa------p. 41

FIGURA 5 - Reprodução gráfica de textos descritivos de terremoto de 1755----------p. 41

FIGURA 6 - Reprodução gráfica do plano de Lisboa, Eugénio dos Santos-------------p. 41

FIGURA 7 - Reprodução gráfica da planta parcial de Lisboa----------------------------p. 44

FIGURA 8 - Reprodução gráfica do maremoto de Lisboa, 1755--------------------------p. 46

FIGURA 9 - Reprodução gráfica do painel de azulejos de Lisboa-----------------------p. 46

FIGURA 10 - Reprodução gráfica da “Gare de Saint Lazare”, Claude Monet---------p.116

FIGURA 11 - Reprodução gráfica de foto aérea de Lisboa---------------------------------p.124

FIGURA 12 - Reprodução gráfica do “Zé-Povinho”, de Bordalo Pinheiro-------------p.125 


\section{SUMÁRIO}

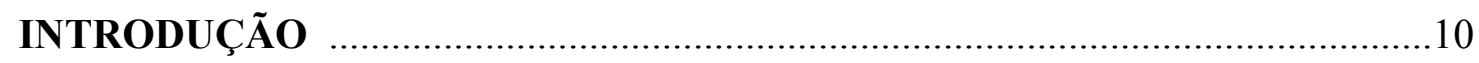

CONTEXTUALIZAÇÃO

À GUISA DE BIOGRAFIA

FORTUNA CRÍTICA

CAPÍTULO I - SUJEITO POÉTICO .37

O SUJEITO E A CIDADE

O SUJEITO E O TEMPO

O SUJEITO E O MUNDO

CAPÍTULO II - ESPAÇO FÍSICO E ESPAÇO DA EMOÇÃO 67

COTIDIANO E PERCURSO

ANTINOMIAS DIALÉTICAS

CAMINHAR E ESCREVER

CAPÍTULO III - LEITURAS DE MUNDO E FORMAS DE EXPRESSÃO .97

ARTE E REALIDADE

RELAÇÕES SOCIOESPACIAIS NA OBRA POÉTICA

IMAGENS IMPRESSIONISTAS NA EXPRESSÃO VERBAL

CONCLUSÃO 120

REFERÊNCIAS BIBLIOGRÁFICAS 131

SITES CONSULTADOS 140

ÍNDICE GERAL 141

ANEXOS - A, B, C, D, E, F, G

FIGURAS - 1, 2, 3, 4, 5, 6, 7, 8, 9, 10, 11,12 


\section{INTRODUÇÃO}

"Fisicamente habitamos um espaço; sentimentalmente, uma memória. $\mathrm{O}$ espaço físico é a cidade, o espaço sentimental é a memória." 1

(José Saramago)

A obra poética de Cesário Verde tem suscitado ao longo do tempo várias possibilidades de interpretação tanto do leitor comum quanto do estudioso. Essas interpretações contemplam as remissões que o poeta faz ao passado, ao presente e ao futuro. Por outro lado, alguns pesquisadores têm-se dedicado com afinco ao levantamento da biografia, incluindo os pseudônimos de que Cesário se valeu como Cláudio e Margarida, para tornar públicas suas composições, omitindo a identidade. Outros ainda, como Joel Serrão, têm-se dedicado à contextualização da época em que o poeta viveu e escreveu seus versos e à fortuna crítica, bem como ao estudo sistemático em constante expansão e aprofundamento de sua poesia. A obra poética de Cesário mostra-se reveladora da crise portuguesa oitocentista e expressa, simultaneamente, a busca de esperança por dias melhores. Nesse sentido, no que se refere à crise oitocentista, remete o leitor à visão aristotélica da arte enquanto verossimilhança, e, em outro, enquanto busca de esperança de um mundo ideal, sugere a concepção platônica. Tanto em um caso como em outro, as imagens poéticas se manifestam como expressão da fragmentação do sujeito e do mundo e como forma de recompor uma totalidade, através da linguagem verbal escrita do poema.

Esta dissertação ${ }^{2}$ se propõe a partir da análise do poema o Sentimento dum Ocidental (ANEXO-A) estender-se a toda obra poética cesariana, levando em consideração estudos já realizados sobre o "Livro de Cesário Verde”, cuja edição primeira data de 1887. Propõe-se, também, na medida em que sua peculiaridade poética aponta para horizontes que vão além

\footnotetext{
${ }^{1}$ José Saramago. 17 de Setembro de /2008. Inauguração do Blog. - RTP.

${ }^{2}$ Primamos em usar as Normas da ABNT e do Novo Acordo Ortográfico (2008) nesta dissertação.
} 
dos propostos pelo Realismo e Naturalismo, compreender o autor e sua época e, guardadas as devidas aproximações e distanciamentos, refletir sobre ela e sobre o nosso próprio tempo presente. Tendo em vista as relações sujeito-tempo-espaço, que evidenciam o movimento constante de fragmentação e busca de totalidade dessas relações, buscamos nesta dissertação analisar os procedimentos estilísticos de que Cesário lança mão para recriar-se, enquanto poeta, e recriar o mundo, enquanto poesia. Isto posto, cabe apresentarmos a seguir o tema, justificativa, objetivos e metodologia a que recorremos neste trabalho.

A ideia central aqui desenvolvida diz respeito ao papel representado pelo poema $O$ Sentimento dum Ocidental, no conjunto da obra de Cesário Verde. Em primeiro lugar, por sua coesão que sintetiza uma visão de mundo, em segundo lugar, em decorrência, por constituir uma súmula da problemática cesariana, não só dos poemas dessa fase ou ciclo específico, mas do conjunto da obra poética do criador de $O$ Sentimento dum Ocidental $(\mathrm{OSO})^{3}$. A análise deste poema, verso a verso, imagem a imagem, somada a releituras sem conta de toda a poesia de Cesário, tem apontado para essa confirmação, por se tratar de um poema que concentra as grandes linhas de força e os núcleos essenciais de sua poesia, como veremos a seguir. Justificamos, também, tal escolha, por sua obra dialogar com a de vários escritores portugueses de sua época e posteriores a ela, ao inaugurar linhas diferentes em relação à tradição. A lírica, voltada para o cotidiano e prosaísmo, faz com que Cesário Verde seja eleito por gerações futuras como referência. Sua importância na medida em que é seguido significa que imaginou linhas de força e formas de expressão que vão além de seu tempo, presentes em escritores posteriores a ele, até mesmo nos dias de hoje, como podemos observar nos poemas de autores brasileiros e portugueses, transcritos nos anexos citados ao longo da dissertação. De início, a análise enfocará OSO e, em seguida, a propósito de alguns temas, chamaremos outros poemas. Isso implica a ideia de prevalência

\footnotetext{
${ }^{3}$ Critérios adotados para análise deste poema e da obra constam do primeiro e segundo parágrafos da p.19
} 
da unidade poética de Cesário, a despeito de sua aparente diversidade temática. Neste sentido, sobre a oposição cidade/campo, Margarida Vieira Mendes pondera: "Este é o aspecto temático mais constantemente abordado pelos leitores de Cesário, ao longo do século XX”. E adverte: "Convém lembrar que, no século passado, afora umas Farpas que Ramalho Ortigão dedicou à moda poética baudelairiana a propósito de Esplêndida, não há a assinalar nenhum estudo sobre a poesia de C. V." ${ }^{4}$. David Mourão Ferreira trata essa dicotomia como essencialmente imagística, quando diz que, mesmo nos poemas citadinos, aparecem "fugas" para imagens campestres. Helder Macedo a considera presente na raiz alimentadora de toda a obra de Cesário.

A questão social é outro aspecto temático que contribui naquele mesmo sentido se entendido como raiz "que atravessa geneticamente grande parte da poesia de Cesário e tem sido freqüentemente tratada, por vezes de um modo um tanto impressionista." 5 Entretanto, não é nosso propósito primordial discutir especificamente essa questão, embora ela esteja presente ao longo da dissertação e, principalmente, no capítulo três. Se como pretendemos, o poema $O$ Sentimento dum Ocidental é uma síntese da problemática cesariana, isso já mostra a unidade fundamental da obra. Seria, por assim dizer, a chave de toda a sua poesia. Para comprová-lo, percorremos um caminho de ida e volta: de um lado, o Sentimento dum Ocidental, entendido como ponto de partida, núcleo gerador do restante dessa poesia; de outro, concebido como ponto de chegada. De um lado, portanto, temos a disseminação das perspectivas que a partir dele se observam na obra; de outro, temos a recolha da diversidade de elementos que estão ali disseminados. Porém, não é uma leitura diacrônica ou uma relação antecedente-consequente que buscamos e, sim, é conceber tal poema como irradiador e síntese de várias características da obra de Cesário. Foi adotado, então, critério

\footnotetext{
${ }^{4}$ MENDES, Margarida Vieira. Poesias de Cesário Verde. Lisboa: Editorial Comunicação, 1987, p. 20.

${ }^{5}$ Idem. ibidem, p. 21.
} 
da sincronia, que, ao contrário, permitiu uma visão simultânea de algumas características disseminadas e do núcleo gerador delas, como veremos mais adiante.

Inicialmente, foram adotados dois procedimentos: um, analítico, que adere ao poema, a fim de lhe explorar as particularidades, procedimento embasado nos conceitos teóricos que fundamentam a análise e interpretação do texto; e, outro, sintético, que se afasta do poema, para generalizar e estender ao conjunto da obra de Cesário os resultados obtidos dessa análise e interpretação. Ambos os procedimentos foram planejados para cumprir o objetivo da dissertação, que é a análise das relações espaciotemporais da obra poética de C V a partir do poema $O$ Sentimento dum Ocidental.

Das linhas de força, duas foram escolhidas por serem mais evidentes no poema $O$ Sentimento dum Ocidental e por perpassarem a obra como um todo. São elas: subjetividade e objetividade, cotidiano e existência. Ambas relacionadas entre si pela tensão sujeitomundo, presente na obra poética como um todo, o que revela a visão de desconcerto de mundo do poeta ante a ordem então estabelecida. Sobre subjetividade e objetividade, podemos dizer, em decorrência das reflexões sobre OSO, que ela estabelece a articulação a partir da situação "entre": entre a objetividade do mundo físico, material, geográfico, cotidiano, que remete ao gênero da epopeia tradicional, no sentido objetivo da busca nas narrativas de percurso; e a subjetividade do sujeito lírico, ou seja, a projeção da emoção, da memória, do imaginário, na expressão lírica. Quanto a isso, temos por base o precedente em Massaud Moisés, quando ele afirma sobre o poema em causa: "[...] lirismo "realista", porém não-fotográfico nem frio: o poeta emociona-se, e muito, e é sua emoção perante o real cotidiano que procura transmitir ao leitor." E, em seguida: "E sua emoção revela existir no seu espírito uma ambivalência, quer dizer, a paisagem citadina o seduz como um visgo, e ao mesmo tempo o repele, tornando-o um estranho a vagar sem rumo..." ${ }^{6}$. Quanto à

\footnotetext{
${ }^{6}$ MOISÉS, Massaud. A Literatura Portuguesa através dos textos. $4^{\mathrm{a}}$. ed. São Paulo. Editora Cultrix, 1971, p.313.
} 
segunda linha de força, cotidiano e existência, acima mencionados, valemo-nos a princípio da obra "A Invenção do Cotidiano", de Michel de Certeau, porém outras leituras, tais como “O Cotidiano e a História", de Agnes Heller, "Psicanálise do Quotidiano", de Fábio Hermann complementaram ou dialogaram com ela no decorrer da dissertação. Acerca da existência, os conceitos de Sartre e Heidegger no que se referem a "ser" e "ser-no-mundo" foram evocados, conforme o aprofundamento da análise o demandou.

A dissertação está organizada em três capítulos articulados entre si e com a Introdução e a Conclusão. São eles: Capítulo I - O sujeito poético; Capítulo II - Espaço físico e espaço da emoção; Capítulo III - Leitura de mundo e forma de expressão. Entretanto os assuntos tratados em cada capítulo não se limitam a ele e, sempre que necessário à análise da obra poética de Cesário, foram evocados em seus diferentes aspectos, sentidos e perspectivas, nos outros capítulos. Se por um lado tal procedimento causa a impressão de que a dissertação se alongou, por outro lado o movimento de retomar ou adiantar os assuntos trouxe certo grau de organização das ideias, mais próximo da poesia. Assim, cada parte só pode ser apreendida na relação com o todo.

No Capítulo I a atenção se volta ao sujeito poético, cuja fragmentação, para fins exclusivos de análise, em sujeito observador e sujeito lírico, quer evidenciar que o diálogo entre eles é uma constante busca de totalidade do ser. Se o sujeito observador, ao longo do percurso a pé pelas ruas de Lisboa, vai captando o espaço fragmentado através dos sentidos, o sujeito lírico vai recompondo a totalidade do espaço pelo olhar. Coube aqui recorrer ao "Seminário 11", de Lacan, para maior entendimento da distinção entre olho e olhar, partindo do pressuposto que olho é a perspectiva, o ponto do qual o sujeito vê; e olhar corresponderia à visão, ou seja, às formas de percepção do simbólico e da cultura, incluindo aí a dimensão temporal expressa em OSO, que é reiterada em outros poemas. Consideramos, com pretensões a maior compreensão da verossimilhança, para fins de 
análise do poema e reconhecimento da visão de mundo do poeta, necessários os estudos sobre o espaço e recorremos às obras "Temas Oitocentistas", de Joel Serrão; "A Natureza do Espaço: técnica e tempo, razão e emoção", de Milton Santos; e "A Cidade em Portugal”, de Teresa Barata Salgueiro.

No Capítulo II, que diz respeito ao cotidiano e ao percurso, buscamos refletir sobre o dia a dia e o caminhar, à luz de alguns conceitos que possibilitaram a melhor interpretação das relações espaciotemporais pelo movimento de fragmentação e totalidade depreendido do poema, como é o caso das noções de próximo e distante, dentro e fora, horizontalidade e verticalidade. Consultamos as obras de Gaston de Bachelard e Iuri Lotman, dentre outras, para análise e interpretação das antinomias dialéticas que tornam visível o invisível. Abordamos a relação campo-cidade em OSO, para melhor compreensão do uso do espaço na obra como um todo. Os grandes motivos de inspiração, Cesário aprendeu-os na escola da vida e do dia a dia, nas relações comerciais e de vizinhança, entre outras, em Lisboa e seus arredores. Seus passeios e trajetórias pelas ruas da cidade proporcionaram-lhe, como observador arguto da realidade que demonstrou ser, o cotidiano da vida lisboeta, o qual registrou com verossimilhança nas suas composições. Partimos, então, da reflexão de que Lisboa, no poema, é recriada pelo poeta em sua complexidade dinâmica de "território usado", à verossimilhança de sua realidade geográfica. Para efetuarmos a análise por esse viés, valemo-nos, também, das obras "Técnica, Espaço, Tempo: Globalização e Meio Técnico-Científico-Informacional" e "Pensando o Espaço do Homem”, de Milton Santos ${ }^{7}$, as quais nos possibilitaram, por transposição disciplinar, salvaguardadas as diferenças entre elas, identificar no poema a fragmentação espacial,

\footnotetext{
${ }^{7}$ SANTOS, Milton. A Natureza do espaço: técnica e tempo; razão e emoção. S P: Hucitec, 1999. Técnica, Espaço e,Tempo: Globalização e Meio Téenico Científico Informacional. SP: Hucitec, 1998. Pensando o Espaço do Homem. São Paulo: Edusp, 2007.
} 
segundo os conceitos de paisagem, lugar e rugosidade; e verificar a totalidade do território usado, recriado pelo sujeito lírico.

No Capítulo III, para maior compreensão das relações espaciotemporais no poema OSO e na obra como um todo, no que diz respeito ao instantâneo e ao circunstancial, captados pelos sentidos do sujeito, que registra com fidelidade quadros da vida urbana e campestre, lançamos mão de uma abordagem do Impressionismo, enquanto arte pictórica, e depreendemos sua tradução verbal dos versos de Cesário Verde. Embora não faltem ali imagens que remetam à audição, ao olfato, paladar e tato, são predominantes as sensações da vista, logicamente acrescentadas e animadas pelos sons característicos e pela ideia de movimento e intenso colorido. As obras "Impressionismo", de Pierrre Francastel; "A História da Arte", de Ernst Gombrich; "História Social da Arte e da Literatura", de Arnold Hauser; “Cores, Forma, Luz, Movimento: A Poesia de Cesário Verde”, de Jorge L. Antonio nortearam esses estudos.

De modo geral, compreendemos que se trata a obra de poesia descritiva, embora identifiquemos nela elementos esparsos, característicos da narração e até mesmo da dissertação. A partir da descrição, questões como luz, cor, contorno, movimento, dentre outras, foram abordadas como recursos linguísticos que expressam a relação sujeitomundo, ora em extensão, ora em contraposição, através da atmosfera criada nos poemas. Metáfora, parataxe e sinestesia são alguns deles, bem como o ponto de exclamação, cujo uso indica ora a indignação e rebeldia, ora a comiseração e compaixão do sujeito em relação ao outro, à nação e à existência. Ainda no campo da estilística, verificamos que um dos traços mais pertinentes em toda sua poesia é a predominância do assíndeto, significando a organização e a lógica compositiva por justaposição de imagens. Pares dialéticos, frases nominais e dêiticos de que Cesário lança mão para expressar sua lírica são reveladores das relações socioespaciais na obra poética, bem como da visão de mundo do 
autor. Questões de ordem estéticoestrutural como estrofação, rima, ritmo, cesura, enjambement, sem se olvidar atenção à camada fônica, morfossintática e semântica, sempre que a análise do poema o demandou foram consideradas. Entretanto, vale ressaltar que "A interpretação separa em partes distintas o que em sua origem é enigmaticamente uma coisa só. Além disso, ela não pode nunca desvendar todo o mistério da obra lírica." 8

A metodologia foi se constituindo da leitura de obras conforme a análise exigiu, sempre em contínuo diálogo com o texto poético em questão; às vezes, em consonância com ele; outras, em discordância dele.Alguns dos principais conceitos, que fundamentaram teoricamente a análise e as reflexões inerentes a cada capítulo, já se encontram inseridos neles; outros necessitaram do uso do destaque como citação, ou porque a precisão com que foram expressos era essencial à compreensão do texto, ou porque a fragmentação ou adaptação lhes comprometeria o sentido. Tanto em um caso como em outro, a coesão e a coerência pautaram sua incorporação ao texto dissertativo. Nesse sentido, obras tais: “Estrutura da Lírica Moderna”, de Hugo Friederich; "Conceitos Fundamentais da Poética”, de Emil Steiger; "Versificação Portuguesa", de Said Ali; "Estilística da Língua Portuguesa", de Rodrigues Lapa; "O Estilo nos Textos", de Norma Discini, "Filologia e Lingüística Portuguesa", de Guaraciaba Micheletti; "Dialogia na Literatura Portuguesa", de Lílian Lopondo, estão entre os principais consultados; e "Elementos de análise do discurso", de José Luiz Fiorin, "Estrutura do discurso da poesia e da narrativa", de Maurice-Jean Lefebve"; "Inútil Poesia”, de Leyla Perrone-Moisés; "Charles Baudelaire: um lírico no auge do capitalismo", de Walter Benjamin, entre os complementares. Outros mais tiveram leitura pontual, como é o caso de: "Um ramalhete para Cesário", de Stephen Rechert; "Subconsciência e afetividade na língua portuguesa", de Jesus Bello Galvão. Todos eles constam das obras relacionadas nas Referências Bibliográficas. Quanto aos

\footnotetext{
${ }^{8}$ STEIGER, Emil. Conceitos Fundamentais da Poética. 33. ed: RJ: Tempo Brasileiro, 1997, p.21.
} 
anexos e às figuras utilizadas, procuramos selecionar os mais significativos para esclarecer as relações texto-contexto, arte-realidade, tempo-espaço e biografia-poesia. Assim, retratos da obra e do autor, mapas, foto e desenho de Lisboa e pintura impressionista foram aqui reproduzidos de sites da internet ${ }^{9}$, para elucidar questões abordadas nos capítulos. Constam, também, anexos alguns textos de autores da época e posteriores, que interagem com a poesia de Cesário Verde, o que denota a importância crescente de sua obra no panorama literário até nossos dias.

Este trabalho se propõe ser uma pequena contribuição para análise e interpretação das relações espaciotemporais na obra poética de Cesário Verde, a partir do poema $O$ Sentimento dum Ocidental, ao que consta não haver igual, justificando com isso sua razão de existir. Cumpre ressaltar que seu intuito não se limita a uma visão interior do texto, mas propõe um diálogo com o mundo do presente do autor e de nossos dias, se contempladas as similitudes e diferenças entre eles. O processo de fragmentação espacial depreendido da análise do poema muito se aproxima em alguns aspectos, salvaguardadas as devidas diferenças, do resultante da globalização do final do século XX e início do século XXI. Não só um novo modo de produção, mas, principalmente, outro modo de vida, ditado pela aceleração, fragmentação socioespacial e valoração de "progresso" técnico acima do humano, que já se faziam sentir na poética de Cesário como angústia existencial e busca de esperança, intensificam-se nos dias atuais, de outra maneira.

Isto posto, cumpre primeiramente apresentar a contextualização da obra, os dados biográficos do autor e a fortuna crítica, na medida em que lançam luzes sobre a compreensão das relações espaciotemporais em sua poesia. Em seguida, apresentamos cada capítulo articulado com o todo e de modo a evitar que o excesso de subtítulos ou subdivisões possa intervir negativamente na inteireza da dissertação, a qual, longe de

\footnotetext{
${ }^{9}$ Sites consultados, após as referências bibliográficas, no final.
} 
pretender a uma completude sobre o assunto, quer ser a continuidade dos estudos existentes sobre o autor e sua obra poética. Neste sentido, o que aqui apresentamos revela não apenas a ideia do que propomos defender, mas a dimensão do trabalho que temos ainda por realizar, no futuro.

Os estudos e as citações de $O$ Sentimento dum Ocidental têm por base a versão publicada em Portugal a Camões (1880), que consta de "Obra Completa de Cesário Verde", $8^{\text {a }}$. edição, organizada por Joel Serrão ${ }^{10}$, cujo prefácio e notas foram de grande valia, por trazerem expressas as várias fontes e os critérios utilizados por ele, o que norteou a pesquisa. Outras edições do poema foram convocadas sempre que a análise assim o exigiu, para cotejamento ou elucidação de algum aspecto pontual. Os demais poemas constam da referida obra de Serrão. Dados biográficos e da fortuna crítica foram extraídos dessas e de outras obras. Para procedimentos de contextualização foram pesquisadas obras que concernem aos dados sobre Lisboa, à época do poeta, e aos estudos sobre o Realismo e Naturalismo português. Outras tantas foram consultadas para elaboração da biografia do poeta e da fortuna crítica.

Cabe, ainda, esclarecer que em relação ao poema $O$ Sentimento dum Ocidental, cuja análise foi mais minuciosa, adotamos o critério de assinalar com algarismo romano a Parte (do poema) e com algarismo arábico, a Estrofe (da Parte) em que se insere o fragmento citado. Exemplo; $($ III-15) $=($ Parte III- Estrofe 15). Em relação aos outros poemas, optamos por indicar apenas o número da Estrofe (E-7). Tal procedimento só foi possível por se tratar de quartetos ou quintetos a maioria dos poemas de que Humilhações (1887) e Nós (1884), Num Bairro Moderno (1877) e Provincianas (1887) são exemplos; alguns tercetos, como é o caso de Cinismos (1874) e Ele (1874), alguns sonetos, a exemplo de A Forca (1873) e Lágrimas (1874), e sextetos de que Manhãs Brumosas (1877) é exemplar único.

\footnotetext{
${ }^{10}$ SERRÃO, Joel. Obra Completa de Cesário Verde. 8. ed. Lisboa: Livros Horizonte, 2003.
} 


\section{CONTEXTUALIZAÇÃO}

A começar pela época em que viveu Cesário Verde (1855-1886), segunda metade do século XIX, cumpre dizer que, com a consolidação do Liberalismo em Portugal, a noção de "progresso" (identificado como os melhoramentos materiais), na esteira da Revolução Industrial, ganha uma força de ideologia oficial. A comunicação técnica, econômica e cultural com o exterior torna-se mais intensa. Em 1864, Coimbra liga-se à Europa pelo caminho de ferro, que logo se estende até Lisboa. Pelo caminho de ferro, cultura, moda e técnica chegam à metrópole "aos caixotes", alterando o modo de produção e modo de vida da sociedade. Tais condições foram propícias à criação intelectual e artística, a qual substituía a cultura clérico-formal por uma cultura liberal e laica. Disto resulta que: "As novas instituições encarapuçavam uma sociedade que sob o ponto de vista tecnológico, econômico e mesmo social estagnava comparativamente." E, assim, "A intensificação da comunicação com o exterior tornava cada vez mais patente, por contraste, a esta situação porque o atraso de Portugal em relação aos países mais adiantados da Europa ia-se acentuando." 11

Um surto das ciências genéticas e de pensadores como Darwin, Comte, Hegel e Proudhon influencia cada vez mais autores portugueses da segunda metade do século XIX. A Associação Internacional dos Trabalhadores lança raízes em Portugal com a cooperação de Antero. O projeto das Conferências do Cassino Lisbonense (1871) integra-se num ambicioso e largo projeto de reforma da sociedade portuguesa. Seu programa impresso e distribuído denota as intenções consoantes à Comuna de Paris (1871) ali difundidas:

\footnotetext{
${ }^{11}$ LOPES, Oscar e Antônio José Saraiva. História da Literatura Portuguesa. Porto: Porto Editora Ltda $5^{\text {a }}$. edição, p.837.
} 
Abrir uma tribuna onde tenham voz as idéias e os trabalhos quecaracterizam esse movimento do século, preocupando-se, sobretudo, com a transformação social, moral e política dos povos; ligar Portugal com o movimento moderno, fazendo-o assim nutrir-se dos elementos vitais de que vive a humanidade civilizada; procurar adquirir a consciência dos factos que nos rodeiam na Europa; agitar na opinião pública as grandes questões da Filosofia e da Ciência moderna; estudar as condições da transformação política, econômica e religiosa da sociedade portuguesa. ${ }^{12}$

Na literatura européia deste período, a publicação em 1857 de "As Flores do Mal” de Baudelaire trouxe um frisson nouveau à poesia, opondo, principalmente, à teologia moralista cristã uma teologia amoral do vício, desarticulando o sentimento da realidade cotidiana pela sugestão de suas correspondências secretas, do domínio da percepção e do raciocínio. Com a derrocada do Segundo Império e a repressão da Comuna Parisiense, declara-se em crise a ideologia progressista e aflora um sentimento de frustração social. Caminhando para o Decadentismo, os poetas sentem-se mais isoladamente artistas e videntes. Assim, Verlaine através da "música antes de tudo", Rimbaud do "longo, imenso e irracional desregramento de todos os sentidos", e da "purificação do sentido das palavras" (palavras de tribo), prática iluminista dos lugares-comuns da linguagem, de Mallarmé, surgem as poesias panfletárias.

A poesia portuguesa de $1870-80$ transcende o moralismo caritativo e o progresso vago da pequena burguesia e, influenciada por Victor Hugo e pelo Parnasianismo descritivo, narrativo e doutrinário, de versificação mais rígida e discursiva, contrasta com a plasticidade e versilibrismo de Verlaine e Rimbaud. As "Odes Modernas" de Antero e os poemas satânicos do pseudo Fradique salientam esta influência.

Nesse contexto, merece atenção especial Cesário Verde a quem se devem, além da expressão poética superior da pequena burguesia lisboeta irreligiosa e republicana, os

\footnotetext{
${ }^{12}$ Idem, ibidem: p. 843.
} 
versos mais representativos do cotidiano urbano e rural da década de oitenta. Conseguindo superar a herança romântica com seu tom natural, como se lê no comentário a seguir:

Era uma poesia original, sem dúvida; mas ornavam-na decorações plebéias, grosseiras, então só vistas em romances dum realismo frenético. O talento de Cesário Verde conseguiu esfumar castamente os aspectos desprezíveis ou repulsivos destes assuntos, refinando-os em cores vivazes, gratíssimas, e orquestrando-os em ritmos apropriados à idéia expressa. $O$ Sentimento dum Ocidental, por exemplo, há retalhos dum impressionismo incomparável, onde as palavras têm sugestões pictóricas, e é íntima a concordância musical entre a idéia e a forma. ${ }^{13}$

Quase sem precedentes este poeta descobre a beleza enérgica dos trabalhadores, como as vendedoras ambulantes de peixe e os operários da construção civil; vibra com o tinir de utensílios dos ofícios manuais, como a forja e os parafusos, sente simpatia pela cidade viva. Por vezes é acometido dum “desejo absurdo de sofrer”, como expressa através dos versos de OSO, no enjoo do gás extravasado, ao chorar do piano das burguesinhas, ao toque das grades das cadeias, aos focos infecciosos da febre amarela, por exemplo. Mundo do cotidiano até então desconhecido da poesia, embora já descoberto pela prosa de Tolentino e Eça, entre outros autores da época. Em carta a Silva Pinto escreveu Cesário sobre uns versos que lhe remetia: "lembram um poliedro de cristal". Compreende-se por isso uma poética translúcida, multifacetada, nítida qual diamante polido. Em outras palavras, a representação da fragmentação de mundo que, pela escrita, busca totalizar está expressando o antigo desejo humano de totalidade, universalização, de Cosmos, que ressoa a eterna busca humana da perfeição das coisas e a rejeição da morte. Consoante Margarida Vieira Mendes: "O que constitui essa poesia, toda ela narrativa, é uma incessante luta de

\footnotetext{
${ }^{13}$ FERREIRA, Joaquim. História da Literatura Portuguesa. 4 a ed. Porto: Editorial Domingos Barreira, 1971, p.952.
} 
resistência a qualquer princípio maligno e desagregador, derivado da morte." ${ }^{\text {. }}$. Ao longo de cada poema o sujeito vai sendo engendrado nesse combate, ao tentar ganhar identidade e consistência, que a princípio lhe faltam, através da escrita que possibilita sua sobrevivência. Exemplo claro está no poema $O$ Sentimento dum Ocidental: "Se eu não morresse nunca! E eternamente/Buscasse e conseguisse a perfeição das cousas!” (IV-4)

Depreendemos daí que Cesário renovou a lírica tradicional portuguesa, valorizando poeticamente o vocabulário e o tom coloquial da linguagem urbana, adotando um ritmo que ondulava entre a degradação que oprime o ser humano e a beleza que o expande. Neste sentido, a visão da cidade como metáfora do Ocidente (civilização industrial do século XIX) corresponde ao sentimento do ocidental que permeia a poesia cesariana e que se opõe ao campo, onde o trabalho e o ar puro garantem a vitalidade, sem, entretanto, impedir a doença e a morte, como bem demonstra a análise do poema Nós, mais adiante.

\section{À GUISA DE BIOGRAFIA}

Sobre sua vida, cumpre lembrar que José Joaquim Cesário Verde nasceu em 25 de fevereiro de 1855 , foi batizado a 2 de junho na igreja paroquial da freguesia lisboeta de Santa Madalena. O segundo de cinco filhos - duas meninas e três meninos - do casal José Anastácio Verde e Maria da Piedade dos Santos. Os pais, além de um estabelecimento comercial de ferragens na Rua dos Fanqueiros, no.9, onde também habitavam, no terceiro andar, dedicavam-se aos trabalhos agrícolas na propriedade rural de Linda-a-Pastora, cuja produção de uvas era também usada na fabricação de vinho para consumo interno e exportação. Exportavam frutas para a Inglaterra, França, Brasil e Estados Unidos. Em 1860 a família muda-se para a Rua do Salitre, 107 (hoje 5), onde permanece até 1877, quando se

\footnotetext{
${ }^{14}$ Idem, ibidem., p.29.
} 
instala na Rua das Trinas do Mocambo, 50 (hoje 36). Era o primeiro dos três varões e nascido entre duas irmãs, Adelaide Eugênia e Maria Júlia, que morreram precocemente, aquela aos três e esta aos 19 anos, vítimas de epidemias que assolaram Lisboa, mesmo tendo a família se refugiado em Linda-a-Pastora. Ele perdeu, também, o irmão Joaquim Tomás, quando este tinha 24 anos, nas mesmas circunstâncias, em 1882, restando apenas Jorge Verde, o único que sobreviveria ao poeta. Aos dez anos, Cesário faz o exame de instrução primária em escola e, depois, dedica-se ao auxílio dos negócios da família, quer na cidade ou no campo. Sabe-se que em 1873 ingressou e frequentou, sem, entretanto, concluir o Curso Superior de Letras, onde conheceu o amigo Silva Pinto. Neste ano começa a publicar poemas no Diário de Notícias e, mais tarde, em outros periódicos de Lisboa, de Coimbra e do Porto. Algumas de suas poesias suscitaram polêmica veemente, em virtude de Cesário, sendo um inovador da lírica portuguesa, não ser bem compreendido em seu tempo, como veremos mais adiante, ao tratarmos da fortuna crítica. Comerciante, Cesário viaja a Paris a negócios em 1883, encontra-se com amigos portugueses que lá residem e tem contato direto com as obras dos pintores impressionistas, artistas que Portugal não possuía notórios.

Filho de burgueses abastados e inconformado com as injustiças sociais de seu tempo, Cesário viveu entre a poesia e os negócios do pai, entre a cidade e o campo, entre a realidade objetiva do mundo e o lirismo subjetivo, entre o patrão e o empregado, entre o operário e o camponês, entre a luta por sobrevivência e a perda dos irmãos, entre a angústia e a esperança, entre o dia e a noite. Essa relação entre fragmentos opostos transparece na totalidade de seus poemas, através de imagens do cotidiano e da existência. Morreu tuberculoso, precocemente, com 31 anos e quase oito meses, no dia 19 de julho de 1881 . Seu único livro intitulado "O Livro de Cesário Verde" (1887) foi coligido e editado por Silva Pinto, em abril do ano seguinte, com uma tiragem de 200 exemplares, que foram 
distribuídos pelo editor e pelo irmão Jorge aos familiares e amigos do poeta. A segunda edição - e a primeira lançada a público - data de 1901, com a informação de que se tratava de uma reimpressão textual da primeira. A terceira edição, impressa em 1910, vem à luz em 1911. Outras se sucederam até nossos dias, algumas corrigidas, outras ampliadas e outras acompanhadas de notas e pareceres sobre estudos dedicados a elas por pessoas de vários lugares, como veremos a seguir.

\section{FORTUNA CRÍTICA}

Salvo raras exceções, Cesário Verde não foi bem acolhido pelos escritores e literatos de seu tempo, entretanto seu valor foi reconhecido posteriormente e a fortuna crítica de sua obra tem sido constantemente enriquecida em Portugal e no Brasil. Mesmo autores como Ramalho Ortigão, Fialho de Almeida e Teófilo Braga, com quem o poeta viria a se relacionar depois, fustigaram e arranharam seus escritos iniciais. Ramalho, n'As Farpas (1874) pede-lhe que "seja menos verde e mais cesário"; e, na opinião de Teófilo, "um poeta amante e moderno devia ser trabalhador, forte e digno e não devia rebaixar-se assim", referindo-se ao considerado "baudelairianismo" de Esplêndida (1874). ${ }^{15}$, poema em que o sujeito lírico "poeta solitário" se propõe a ser "truão" de uma aristocrata. A resposta ferina de Cesário se fez através do poema satírico Ele (Ao Diário Ilustrado), impresso em folha avulsa e distribuído em Lisboa (1874) ${ }^{16}$, em cujo último verso se lê: "Nascera o Ilustrado - um vômito real."

Angelina Vidal, sob o pseudônimo de Juvenal Pigmeu, minimiza o talento de Cesário ao afirmar no jornal Tributo do Povo (1879): “[...]Fernando Leal e Bettencourt Rodrigues, dos quais um só cabelo vale mais que todos os verdes presentes, futuros,

\footnotetext{
${ }^{15}$ Apud SERRÃO. 2003. Op. cit. , p.13.

${ }^{16}$ Apud SERRÃO. Joel, 2003. Idem, ibiden, p. 50.
} 
prováveis e possíveis. "17 O Diário Ilustrado (4 de outubro de 1879) critica cada verso de Em Petiz, publicado no Diário de Notícias (29 de setembro 1879), como "um vomitório, e onde em cada recordação se revela de sobejo os maus instintos da criança, e presentemente o desamor do homem já feito pela desgraça e miséria alheias". ${ }^{18}$

O "retrato" do poeta que Fialho nos legou é pintado, entre outras, com tintas de ironia, como se nota no tom de algumas expressões: "ingênua arrogância", "pele de fêmea loira" e "olhos amarelo-pardos de estátua", como se lê:

“[...] alto e mui grave, vestido de azul e com um colarinho voltado sobre uma gravata escarlate, tinha bem a figura do caráter, e não se podia mirá-lo sem logo lhe ver, na ingênua arrogância, o querer que fosse do ser filtrado misteriosamente por uma estranha seleção. O tipo era seco, com uma ossatura poderosa, a pele de fêmea loira, rosada de bom sangue, a cabeça pequena e grega, com uma testa magnífica, e feições redondas, onde os olhos amarelo-pardos de estátua, ligeiramente míopes, tinham a expressão profunda, retilínea, longínqua, que a gente nota nos dos marítimos acostumados a interrogar o oceano por dilatadas extensões." 19

Na antologia "Parnaso Português Moderno" (1877), organizada, prefaciada e publicada por Teófilo Braga, não há referência a Cesário. Neste mesmo ano, Jaime Vitor traça o perfil de Cesário em um soneto publicado em O Contemporâneo, no qual relaciona seu "entusiasmo" à Taine e Proudhon como mera cópia. Já em 1873, Eduardo Coelho que o batiza de "Um poeta negociante" descreve-o assim: "é um moço quase imberbe, ingênuo, rosto e alma serena, fronte espaçosa, olhar perscrutador, cheio de aspirações elevadas."20, sem referência a sua poesia.

No decorrer do tempo alguns buscaram rever suas opiniões. Tal é o caso de Henrique Lopes de Mendonça que havia comentado, quando da morte do poeta, em 1886:

\footnotetext{
${ }^{17}$ Apud SERRÃO. Idem, ibidem, p.16.

${ }^{18}$ Apud SERRÃO. Idem, ibidem, p.16.

${ }^{19}$ CUNHA, Teresa Sobral. Cânticos de Realismo e outros poemas. 32 cartas. Lisboa: Relógio D’Água Editores, 2006, p. 44.

${ }^{20}$ Diário de Notícias, 12 de novembro, 1873. Apud. SERRÃO, op.cit., p.13.
} 
“[...] a tua obra, pequena e dispersa, não é daquelas que se impõe à admiração incondicional da posteridade", esboça no Jornal de Domingo do ano seguinte sua atitude crítica ante a poesia do falecido amigo:

\begin{abstract}
“[...] na obra do poeta, me choca por vezes a procura intencional de originalidade, que destrói a espontânea e brilhante factura dos versos; a excêntrica invasão do prosaísmo, que perverte e corrói a poesia na sua própria essência; a substituição das estafadas metáforas do lirismo romântico por outras, sem dúvida mais extravagantes, mas com certeza menos racionais e compreensíveis; a adjetivação imprevista e abstrusa, que freqüentemente dirime, enquanto a mim, a poética singeleza do pensamento." 21
\end{abstract}

Ante o não reconhecimento de sua poesia Cesário lamenta o descaso e demonstra certa mágoa, como é o caso da carta enviada a Macedo Papança, por ocasião da publicação de O Sentimento dum Ocidental, no Jornal de Viagens (Porto, 10 de junho de 1880): "Uma poesia minha, recente, publicada numa folha bem impressa, comemorativa de Camões, não obteve um olhar, um sorriso, um desdém, uma observação." ${ }^{22}$ Em carta a Silva Pinto (1879), já confidenciava seu desânimo em relação ao fazer poético e sua dedicação à gerência da firma familiar: "Eu por aqui me afasto da literatura; amando-a muitíssimo, não penso exclusivamente nela." Neste mesmo ano, desabafa em carta a Bettencourt Rodrigues, então estudando em Paris: "Ah! Meu amigo, se tu me tirasses desta apatia, deste enervamento, como seria bom! Seria impossível, completamente, numa formidável capital de trabalho, de inteligência, de febre, arranjar um cantinho para mim? Um ano, um ano só para me desemburrar!" 23

\footnotetext{
${ }^{21}$ Jornal de Domingo, Lisboa, 31 de julho de 1887. Apud. SERRÃO, op. cit. p.20

${ }^{22}$ Carta datada de 29 de agosto de 1880. Apud. CUNHA, Teresa Sobral. op. cit., p. 212.

${ }^{23}$ Linda-a-Pastora, 16 de novembro de 1879. Apud. CUNHA, op.cit. p.208
} 
Do encontro com Cesário, Bettencourt Rodrigues e os pintores Antônio Ramalho e Artur Loureiro, em Paris, em 1883, Mariano Pina testemunha: "Ele bem queria me convencer que o poeta tinha morrido, e que hoje só pensava numa vida laboriosa e activa de negociante, conhecendo a fundo a sua especialidade." 24

A fotografia aos 16 anos na Calçada do Duque, em frente ao portão da escola, e o retrato pintado por Columbano posteriormente (FIGURA 1) indicam que era pessoa conhecida em seu meio. Entretanto, nos jornais que noticiaram a morte de Cesário, há alguns desencontros de opiniões quanto a seu reconhecimento como poeta: "Poeta apreciável" (Diário de Notícias); e A Revolução de Setembro ${ }^{25}$ sobre os "enterramentos" de 20 de julho de1886 limita-se à notícia "José Joaquim Cesário Verde, 32 anos, solteiro." Já o Jornal do Comércio declarava: "Cesário Verde morre quase ignorado. Circunstâncias especiais da sua vida fizeram talvez com que ele não pudesse apurar as suas faculdades, nem aperfeiçoar os seus processos artísticos;” e conclui, “mas o que dele fica basta para revelar uma decidida vocação poética, original e independente como poucas." ${ }^{26}$ E Mariano Pina, em A Ilustração, Paris, ponderava: “A minha geração perde em Cesário Verde um dos seus espíritos mais originais e mais nobres. Não foi um grande artista que morreu." E lamenta: "Morreu o embrião dum grande artista, cujo talento estava destinado a marcar uma época, a triunfar ruidosamente de tudo e de todos." ${ }^{27}$ Nos jornais Correio da Manhã e A Imprensa são estampadas notícias desenvolvidas sobre a morte do poeta, denotando sua notoriedade. Segundo Ricardo Daunt, em 1886: “O Grupo Vida Nova realiza o primeiro encontro no Hotel Bragança, no Chiado, e a morte de Cesário passa quase inteiramente despercebida nos meios literários e jornalísticos.” ${ }^{28}$. Entretanto, em Joel Serrão leem-se,

\footnotetext{
${ }^{24}$ Apud: SERRÃO, op. cit. p. 18

${ }^{25} 22$ de julho de 1886. Apud: SERRÃO, op.cit., 20.

${ }^{26}$ Apud: SERRÃO op. cit. p. 20.

${ }^{27}$ Apud. SERRÃO, op.cit., p.20.

${ }^{28}$ DAUNT, Ricardo. Obra Poética Integral de Cesário Verde. (1855-86). Org. e Apres. Tábua Cronológica e Cartas reunidas por Ricardo Daunt. São Paulo: Landy Editora, 2006, p.44.
} 
sobre a roda de amigos de Cesário, os testemunhos de Mariano Pina, Silva Pinto, Henrique Lopes Mendonça que averbam a publicação dispersa do poeta nas colunas dos jornais e revistas de Lisboa. António Capão assim a organiza, a título meramente informativo: "De Lisboa: Diário de Notícias, A Tribuna, Ocidente, Ilustração. Do Porto: Harpa, Renascença, Jornal de Viagens (Portugal a Camões, edição extaordinária), O Porto, Jornal da Tarde. De Coimbra: Mosaico, Evolução, Revista de Coimbra, Correspondência de Coimbra." 29

Em abril de 1887, duzentos exemplares de "O Livro de Cesário Verde” (FIGURA 2), publicado por Silva Pinto, são distribuídos pelo editor, pelo irmão Jorge Verde e "pelos parentes", pelos amigos e pelos admiradores privados do poeta. Conforme noticiado por Silva Pinto, no Correio da Manhã, Lisboa, 14 de abril de 1887, dá a lume uma recensão de "O Livro de Cesário Verde". Somente a segunda edição de "O Livro de Cesário Verde" (1901), e (a primeira dada ao público) continha a ressalva de que tratava da "reimpressão textual da primeira edição feita pelo amigo do poeta Silva Pinto.” A terceira edição de OLCV, impressa em outubro de 1910, vem a público em 1911, ano da morte de Silva Pinto. Com o incêndio em Linda-a Pastora, que destruiu a ala onde se encontrava o material escrito, o espólio de Cesário fica comprometido, restando ao leitor o que fora dado a lume de sua obra em livro e jornais ou o que, quiçá, ainda se encontra perdido dentro das páginas de algum tomo, fora do alcance de nossas vistas, como foi o caso do poema $A$ débil, encontrado por sorte e empenho de Joel Serrão, na biblioteca de Alberto de Monsaraz; e de Nós, recentemente revelado. Nas palavras de Joel Serrão: "tudo indica que esteja inteiramente perdido o 'original' para a tipografia, preparado por Silva Pinto; se ainda existe, não se sabe por onde parará um exemplar da $1^{\text {a }}$. edição, anotado por Silva Pinto, ao qual Cabral do Nascimento se referiu por esse modo (na "Advertência" à 9a . edição de "O

\footnotetext{
${ }^{29}$ CAPÃO. António. O Livro de Cesário Verde. Texto original e Estudo da obra por António Capão. Porto: Paisagem Editora Ltda., 1982. In: Ficha bibliográfica, s/n.
} 
Livro de Cesário Verde". Lisboa: Minerva, p.12) ${ }^{30}$ : "É voz corrente [...] que há um exemplar da edição princeps emendado por Silva Pinto. Ignoramos onde pára.” 31

Das relações literárias e sociais de Cesário, fora o que revelam suas cartas, há pouca referência, a não ser a algumas tertúlias e encontros com escritores e jornalistas que frequentavam Cafés e a Cervejaria Leão de Ouro, como se lê no fragmento:

Como João de Deus e Guerra Junqueiro, Guilherme de Azevedo professava por Cesário Verde uma simpatia verdadeira e ampla; por muitas vezes naquela cervejaria do Leão, que veio a adquirir tão notável celebridade no nosso mundo artístico, vi o autor da Alma Nova insistindo com o moço poeta para que ele emoldurasse alguns dos seus versos nas páginas do Ocidente. ${ }^{32}$.

Ao que consta, não pertenceu Cesário às coteries da época, que viviam de se injuriar umas às outras. Sabe-se, isto sim, que além de poeta ele era um homem dedicado aos negócios de família, tanto na cidade, na loja de ferragens do pai, José Anastácio Verde, à Rua dos Fanqueiros; como no campo, na quinta Linda-a-Pastora, nos arredores de Lisboa, onde se cultivavam, para consumo interno e exportação, cítricos e vinho, entre outros produtos hortifrutigranjeiros. Este mesmo local, que também abrigou a família Verde durante as epidemias de cólera e febre amarela, as quais assaltaram a capital em 1856 e 1857 respectivamente, não impediu o luto familiar pela morte de Adelaide Eugênia, irmã do poeta, em 1859 .

Ao que consta Cesário era dado a casos amorosos, sem, contudo, haver casado. Se as atividades comerciais aproximaram Cesário de França, Inglaterra e Brasil, sua poesia também dialogou com as tendências européias da época. Exemplo disso é o que o poeta explica a Gaudino Gomes: "não publicaria senão um livro que pela rigorosa seleção e pelo

\footnotetext{
${ }^{30}$ Parêntesis nosso

${ }^{31}$ SERRÃO. 2003. Op.cit., p.26.

${ }^{32}$ CUNHA, Teresa Sobral, op. cit. , p.16.
} 
paciente trabalho da forma pudesse, como "As Flores do Mal" de Baudelaire impor-se, através da aparente descontinuidade das composições, pela unidade cerrada da forma e pela unidade essencial do fundo poético." 33

Lembrando o que dele disseram Fialho de Almeida e Fernando Pessoa, percebemos o prenúncio de sua importância na literatura ocidental, pela aparente descontinuidade das imagens, labor da forma e unidade poética. Fialho conviveu com Cesário a tempo de $o$ amar na vida e na escrita, conforme dão testemunho suas páginas; Pessoa conheceu Fialho, sendo provável que nas tertúlias do Martinho, frequentadas por ambos, pairasse o nome daquele que por suas experiências estéticas e estranha diversidade já era pressentido como "precursor inconsciente" do que viria a ser o Modernismo. A começar pela carta de Fialho de Almeida anteposta ao Prefácio no In Memoriam, organizado por António Barradas e Alberto Saavedra, Porto, Tipografia da Renascença Portuguesa, 1917, onde ele referencia o poeta:

Se te disser, meu caro Gomes, que ao começar escrever dele [Cesário] a mão me treme, e o espírito me divaga sob a cor de um medo religioso; se te contar que há quatro noites redijo notas para elucidar este prefácio, sem que até agora nenhum me explique cientificamente o sonho por onde eu visionava o seu talento, farás idéia talvez da fascinação que esse extraordinário rapaz lançou em meu juízo, e da angústia rude que o teu pedido derrama, amigo, num infeliz prosternado e a dizer como na missa Senhor! Senhor! eu não sou digno... ${ }^{34}$

E, depois, pinçando alguns fragmentos do referido Prefácio que ao mesmo tempo descobrem o poeta, a cidade e vida literária da época, a partir da publicação de Um Bairro Moderno (Brinde aos Senhores Assinantes do Diário de Notícias em 1877), comenta que ele foi vítima de críticas contundentes estampadas no Diário de Portugal e na

\footnotetext{
${ }^{33}$ BOURBON E MENESES. Pedras Soltas, Diário de Notícias, 4 de out. 1929. Apud. Cunha, op. cit., p.15.

${ }^{34}$ ALMEIDA, Fialho de. Prefácio (notas). Apud. CUNHA, op. cit., p. 39.
} 
Correspondência de Coimbra. ${ }^{35}$ Sobre Um Bairro Moderno, poema da maturidade, a que Cesário empresta, ao lado de Cristalizações e de O Sentimento dum Ocidental "o ponto de vista de um sujeito observador transeunte, que se exprime através de um lirismo antideclamatório, embora envolvido pela atmosfera que busca captar" ${ }^{36}$, Fialho pondera que foi decisivo para clarear o entusiasmo que sentia pelo poeta:

[...] fazendo passo a um sentimento de surpresa, e à fé profunda de haver nesse ainda incompleto fraseado a eclosão dum artista único no apercebi mento das exterioridades pitorescas, com o simbolismo elíseo dos infinitamente secretos da alma coletiva, amando os simples, buscando a locução com dor parturiente, traduzindo impressões diretas e pungitivas, como quem só é capaz de criar vocábulo para o que vê, sofre ou medita uma alma de verdade enfim, como diz Shakespeare, uma alma estranha e com a virgindade feroz de escrever poesia semelhando pela nitidez, à bela prosa. A fantasia é hoje familiar entre os artistas, e na parte descritiva, pela instantaneidade evocadora, inigualável, assunto que retomaremos adiante, quando abordarmos o impressionismo em "O Sentimento dum Ocidental. ${ }^{37}$

Ao descrever a cidade de Lisboa, Fialho situa cartograficamente o bairro moderno a que se refere Cesário no poema homônimo, historicizando-o:

Ao tempo quase nenhum dos novos bairros estava sequer na planta camarária: apenas o Estefânia começava a esquadrinhar desencontradamente, a cavaleiro da Bemposta, a Quinta Velha, e Lisboa mantinha ainda matroniciamente o seu feitio antigo, a vida concentrada na Baixa, a gente rica habitando casas de azulejo e esses desamparados casarões do século XVII e sáculo XVIII, que são hoje fábricas, colégios, hospícios ou quartéis, para os lados de Santa Apolônia, Costa do Castelo, Campos de Sant'Ana e Santa Clara, Alcântara e outros pontos há doze anos ainda considerados arrabaldes. O bairro moderno, o bairro luxuoso da colônia estrangeira e dalguns

\footnotetext{
${ }^{35}$ SERRÃO, op. cit., p 16.

${ }^{36}$ DAUNT, Ricardo, op.cit., p.13.

${ }^{37}$ CUNHA, Teresa Sobral, op. cit., p.42. In: Prefácio de Fialho de Almeida.
} 
indígenas de gosto, era, pois Buenos-Aires; esse que inspira os versos trás citados, e por onde Cesário, como mais longe direi, cruzava muita vez. ${ }^{38}$

Ao se referir à vida literária de Portugal, Fialho diz que era naquele tempo o que tem sido sempre, relevando a originalidade da poesia de Cesário, que excedia tudo o que eu lera em poesia impressionista, referindo-se a Num Bairro Moderno ${ }^{39}$

Fernando Pessoa, que dos três mestres de língua portuguesa que elegeu (Antero de Quental, Cesário Verde e Camilo Pessanha), foi ao cantor de OSO, como ele transeunte das ruas de Lisboa e espectador desencantado do fim do império, que ele dedicou a lição do Estudo Crítico sobre o gênio poético, a originalidade e o lusitanismo de Cesário. Datando alguns dos fragmentos do estudo crítico de 1911 e outros de 1923, ambos os manuscritos na maioria das páginas em português e inglês encontram-se os dois reunidos na obra "Cânticos do Realismo e Outros Poemas - 32 Cartas", Edição de Teresa Sobral Cunha. Sobre o gênio poético, Pessoa enfatiza:

Com Antero de Quental se fundou entre nós a poesia metafísica, até ali não só ausente, mas organicamente ausente, da nossa literatura. Com Cesário se fundou entre nós a poesia objetiva, igualmente ignorada entre nós. Com Camilo Pessanha a poesia do vago e do impressivo tomou forma portuguesa. Qualquer dos três, porque qualquer é um homem de gênio, é grande não só adentro de Portugal, mas em absoluto. [...]Cesário foi um revolucionário da literatura. A sua obra foi uma revelação não grande, mas radical. Como todas as revoluções que são radicais sem ser grandes, a obra de Cesário está cheia de defeitos, especialmente de defeitos produzidos pelas próprias qualidades em cuja substituição a outras está o radicalismo. ${ }^{40}$

Sobre a originalidade da poesia de Cesário, Fernando Pessoa pondera:

\footnotetext{
${ }^{38}$ Idem, ibidem, p. 44.

${ }^{39}$ Idem, ibidem, p. 44.

${ }^{40}$ Idem, ibidem, pp. 225 e ss.
} 
Quem ler a obra de Cesário /admira-se/ da admiração que a muitos causa e que lida desprendidamente, e com a expectativa de encontrar grandeza, a obra de Cesário Verde com o que revela de nula imaginação, de nula inteligência, de sentimento circunscrito e até da falta de sentimento estético, assombra pelo que não tem de grande. O segredo está em que essa obra, pobre como é de quase tudo quanto constitui a grandeza poética, possui soberanamente e absorventemente uma qualidade constitutiva da grandeza - a originalidade. ${ }^{41}$

E sobre o sentimento de Cesário, Pessoa elucida:

O sentimento estético não é grande em Cesário. O sentimento é forte e sincero, mas reprimido: e é nisto que Cesário é curioso. É um português que reprime o sentimento. Tem-no, porque é um português, e um português sem sentimento é cousa que não se concebe. ${ }^{42}$

No centenário de sua morte, a revista Colóquio/Letras, da Fundação Calouste Gulbenkian publica poemas de vários autores contemporâneos que versam sobre Cesário. Dentre eles, os de Eugénio de Andrade (ANEXO-B) e Sophia de Mello Brayner Andersen (ANEXO-C). Segundo Carlos Felipe Moisés, Cesário só chega até nós, no Brasil, no início do século XX: “O primeiro a se dar conta é Felipe D’Oliveira. Seu Vida extinta (1911) inclui um longo poema que principia: Eu hoje estou com as crises de Cesário". 43 Manuel Bandeira coloca seu nome no rol dos poetas portugueses glorificados no poema "Improviso" (ANEXO-D): Glória ao sempre Verde Cesário, contrariando o tom irônico adotado por Ortigão em "As Farpas"; e João Cabral de Melo Neto rende a ele sua homenagem no poema $O$ sim contra o sim (ANEXO-E).

\footnotetext{
${ }^{41}$ Idem, ibidem, pp. 225 e ss.

${ }^{42}$ Idem, ibidem, pp. 225 e ss.

${ }^{43}$ MOISÉS, Carlos Felipe. Modernidade. In: O Desconcerto do Mundo: Do Renascimento ao
}

Surrealismo. São Paulo: Escrituras. Editora. Coleção Ensaios Transversais. 2001. p. 201. 
Tal presença de Cesário se constata não só em poesia, como alguns textos acima demonstram, mas em prosa. O conto Saudades para Dona Genciana ${ }^{44}$, de José Rodrigues Miguéis, bem o exemplifica, pela citação nominal do referido poeta e incorporação no texto de elementos da cidade de Lisboa presentes nas imagens de sua poesia, tal a iluminação a gás, o silêncio noturno, a exploração do trabalhador urbano, entre outros: “O luar encharcava a noite, entrava em cascata pelas janelas, vinha ter conosco à cama. As luzes eram raras e mortiças, de gás incandescente. Pairava no ar um resto de Cesário.” No conto, a referência aos habitantes do campo e da cidade, tão presentes na obra de Cesário, se faz representada pelos carroceiros e hortaliceiras a caminho do mercado; pelas costureiras, rumo às oficinas da moda, e a patrulha a rondar pela Avenida e ruas escuras, pelos boêmios e fêmeas a madrugar nos becos e tavernas. A acuidade das imagens auditivas está presente na comparação que se segue: em $O$ Sentimento dum Ocidental, à noite fechada: "Um parafuso cai nas lajes, às escuras"; em Saudades para Dona Genciana: "Pela meia-noite podia-se ouvir cair um alfinete nas pedrinhas da calçada." Ambas as imagens conotam o silêncio da hora e a acurada percepção do sujeito que a expressa. Também o som de uma longínqua flauta e um fado ao bandolim remetem ao efeito sonoro da música nos dois textos. Os costumes são tratados com ironia através de imagens sinestésicas. No poema de Cesário moças burguesas querubins do lar flutuam nas sacadas; no conto de Miguéis, as meninas pensativas dedilhavam pianos lânguidos. Imagens femininas que remetem à idealização da fragilidade romântica em oposição às obreiras do Realismo e Naturalismo.

Outro exemplo da presença de Cesário em obras posteriores a ele encontramos no romance "As Naus", de Lobo Antunes (1988), no que concerne à justaposição de duas cosmovisões que, segundo Raquel de Sousa Ribeiro, "tanto se opõem como se sucedem no tempo. Ambas, entretanto, fazendo parte do mesmo processo: o das grandes navegações.”

\footnotetext{
${ }^{44}$ In: MIGUÉIS, J. Rodrigues. Léah e outras histórias. Lisboa: Editora Estúdios Cor Ltda, 1968, p. 200.
} 
De um lado, personagens com nomes de Pedro Álvares Cabral, Vasco da Gama e Camões, dentre outros, "sugerem a representação da utopia renascentista, antropocêntrica. Ao lado dessa visão de mundo, a mais recente, que reconhece o direito de todos à autonomia, à autodeterminação." 45 Entre estas duas mundividências estão os "retornados", presos à primeira por descendência, à segunda, por nascimento, mas rejeitados por ambas. Tal remete a situação de Cesário e de sua obra poética, na medida em que o homem oitocentista, fragmentado entre a cidade e o campo, busca a totalidade através do trabalho; e o sujeito poético, dividido entre o presente (espaço físico) e a memória (espaço do sentimento) busca a unidade através da poesia.

Como já foi mencionado anteriormente, não se pretende com este breve inventário esgotar a Fortuna Crítica de Cesário Verde. Nossa pesquisa consultou inúmeras obras existentes sobre o assunto, como é, entre outros, o quadro cronológico ${ }^{46}$ das publicações dos poemas com a devida reserva em que Luís Amaro d'Oliveira aponta discordâncias entre as datas de publicação em jornais e revistas, pela primeira vez, no livro organizado por Silva Pinto. Consultamos, também, o sumário ou quadro completo da obra do autor organizado por Joel Serrão. (ANEXO-F).

\footnotetext{
${ }^{45}$ RIBEIRO, Raquel de Sousa. A justaposição n' As Naus, de Lobo Antunes: o silenciado em busca da forma. In: Literatura Portuguesa: História, memória e perspectivas. Aparecida de Fátima Bueno ... [Et Al.]. SP: Alameda, 2007, pp. 337 e 338.

${ }^{46}$ OLIVEIRA, Luís Amaro d’. Cesário Verde (Novos subsídios para o estudo da sua personalidade). Coimbra: Nobel, 1944, pp. 75 e 76.
} 


\section{I - O SUJEITO POÉTICO}

"O que diz tem o calor das coisas proferidas pelo próprio,
saídas diretamente do coração."

(Rodrigues Lapa) $^{47}$

Este primeiro capítulo busca refletir sobre a questão do sujeito poético no poema $O$ Sentimento dum Ocidental e dele para a obra como um todo, a partir das relações espaciotemporais do cotidiano e do percurso. Partimos do princípio analítico de que a constituição do sujeito poético, no caso, realiza-se através de duas vertentes distintas que dialogam entre si e com o mundo. São elas: a observação e captação do mundo exterior, através dos sentidos, e o sentimento decorrente dessa percepção, expresso no poema. Se na Introdução abordamos questões de ordem biográfica, de contextualização e fortuna crítica que possam lançar luzes sobre a análise do referido poema e do restante da obra poética, a título de orientação de leitura, temos em mente que, por mais original que seja o artista, ele reflete em sua obra o mundo a que pertence, como se lê na breve exposição que se segue:

E Cesário Verde viveu e escreveu em uma época em que as teorias científicas procuravam estudar o homem independentemente das explicações religiosas. Além disso, sua família pouco tinha a ver com a religião. Tudo isso parece ter marcado fundo o poeta: sua literatura voltase para a realidade objetiva, material. Sua temática é realista. Em outras palavras, o que lhe interessa é o mundo que o rodeia, é o homem situado na vida terrena. O homem palpável, vivendo num espaço social, que é apreendido pela razão, mas, basicamente, pelos sentidos. São comuns em sua obra versos que descrevem sensações - visuais, auditivas, táteis,

\footnotetext{
${ }^{47}$ LAPA, M. Rodrigues. Estilística da Língua Portuguesa. 6 ${ }^{\text {a }}$ ed. RJ: Livraria Acadêmica, 1870, p.124.
} 
olfativas e gustativas. O mundo de seus poemas é o mundo lisboeta, ocidental. $^{48}$

Buscamos, a partir daí, enfocar as relações entre espaço físico (geográfico) e espaço da emoção (sentimento), num primeiro momento, para, em seguida, analisar os aspectos básicos da relação sujeito-tempo-espaço que, embora se apresentem aqui separados para fins de análise, pertencem a um só texto-contexto.

Cumpre, a título de orientação da leitura, ressaltar que as expressões "sujeito lírico" e "sujeito observador" distinguem-se apenas para efeitos analíticos, tendo a expressão "sujeito poético" o sentido equivalente ao sujeito que compõe e se expressa através dos versos no poema, sendo justificado o uso da variação linguística para evitar repetições vocabulares.

\section{O SUJEITO E A CIDADE}

Na obra poética de Cesário Verde há um jogo de interação constante entre espaço físico e espaço da emoção, do sentimento. Não são raras as expressões em seus versos que denotam sua inspiração a partir do território vivido, seja ele representado por Lisboa ou por seus arredores: “Triste cidade!” e "Quisera que o real e a análise mo dessem” são exemplos referentes a Lisboa (OSO); "No campo, eu acho nele a musa que me anima" (De Verão, E.1) é referente a seus arredores. Lá, na obra como um todo, pela referência geográfica ao Tejo, equipamentos urbanos da cidade, seus locais e monumentos que a identificam; aqui, pelos contrastes do homem e da terra portuguesa com o solo e os farmers dos países do Norte, que os singularizam. Analisar, portanto, a relação entre espaço físico (geográfico) e espaço do sentimento (emoção), buscando evidenciar o diálogo deles na poesia de Cesário

\footnotetext{
${ }^{48}$ PASCHOALIN, Maria Aparecida. Cesário Verde. (Seleção de textos, notas, estudos biográfico, histórico e crítico e exercícios). São Paulo: Abril Educação, 1982, p.98.
} 
Verde, parece-nos importante neste momento, embora saibamos que tal assunto demande aprofundamento maior.

Partindo da análise do poema OSO, que sinteticamente expressa as relações espaciotemporais de Lisboa, nossa análise buscou interpretá-las na obra como um todo. Para tanto recorremos a dados biográficos do poeta e da cidade em que ele viveu como base da realidade recriada em sua poesia pelo sujeito poético. Em outras palavras, Cesário viveu e trabalhou em Lisboa e em seus arrebaldes, por conta da loja de ferragens de seu pai, à Rua dos Fanqueiros, e da quinta Linda-a Pastora, não muito distante dali. Esse espaço inspirou seus poemas. Predomina em sua poesia o movimento do sujeito que, a partir da observação da realidade percebe o sentimento que ela deflagra e o expressa através dos versos, criando, assim, uma nova realidade: a do poema. A partir daí, pareceu-nos essencial à análise e interpretação da obra poética compreender a relação entre o espaço físico e o espaço sentimental dele decorrente, expresso em seus versos. Recorremos, então, a uma série de estudos sobre a situação geográfica de Lisboa à época do autor. Cabe, entretanto, ressaltar que compreendemos essa realidade dentro das limitações que a linguagem impõe e que esses estudos que se seguem decorrem de pretensões a uma maior verossimilhança, mais próximo possível do espaço real, para bem interpretar o desejo que as próprias palavras recorrentes do poeta expressam: "E eu, que medito um livro que exacerbe, / Quisera que o real e a análise mo dessem;/ Casas de confecções e modas resplandecem; / pelas vitrines olha um ratoneiro imberbe". (OSO, III-5).

Em princípios do século XIX, a cidade de Lisboa ocupava uma área de $9.47 \mathrm{~km}^{2}$. Em meados do século (1852) assiste-se ao alargamento do território da cidade que passa a $12.24 \mathrm{~km}^{2}$, ficando limitada pela Estrada da Circunvalação. O comprimento máximo no sentido E-O era de $5.6 \mathrm{~km}$, contra $3.3 \mathrm{~km}$ no sentido N-S. Segundo Teresa Barata Salgueiro: "No último quartel do século XIX a abertura da Avenida da Liberdade e a 
urbanização dos territórios adjacentes alterou a forma tradicional da cidade, que desde então começou a crescer para o norte, em direção ao planalto." ${ }^{49}$ Algumas indústrias se concentravam próximos à zona ribeirinha do Tejo, dotada de maior acessibilidade, pois dispunha de linha de "americanos", transporte coletivo de tração animal, do tradicional "Chora" (FIGURA-3), do caminho de ferro (linhas Norte e Leste), e do porto, onde foram efetuadas importantes obras nos anos oitenta. O Inquérito Industrial de 1881, por exemplo, aponta para maior concentração de emprego industrial nessa região. Para lá da área construída, em continuação, estendiam-se os territórios que abasteciam a cidade de víveres ou matérias-primas, e as que eram utilizadas para lazer dos lisboetas, quintas e praias, desde o fim do século XIX: “As aldeias da região saloia eram sedes de territórios agrícolas que forneciam os produtos das suas hortas, ou o vinho [...] aos mercados da capital." ${ }^{50}$ As estâncias de veraneio e os núcleos industriais mais distantes foram desenvolvidos depois das instalações da linha férrea e, assim, completaram o quadro da periferia de Lisboa já no século XX.

Ao analisar o desenvolvimento urbano em Portugal, Teresa Barata Salgueiro distingue três períodos: o período medieval, o período pombalino e as fases de crescimento mais recentes, cuja origem se situa no século XIX e alcança nossos dias. O primeiro período tem seu início marcado pelas fundações de povoação no princípio da nacionalidade (século XII). Nos séculos XV a XVII, com a criação de cidades além-oceanos como reflexo dos Descobrimentos, a economia essencialmente agrícola afirma-se como vocação marítima e comercial, proporcionando o desenvolvimento de Lisboa, que se trona a capital. Ali, as construções se sucedem sem obedecer a um plano conjunto, e a acumulação de riqueza permite edificações luxuosas, com produtos importados, a gosto da moda européia, e com elementos exóticos que o mundo tropical revelava. Dessa síntese, resultou o estilo

\footnotetext{
${ }^{49}$ SALGUEIRO, Teresa Barata. A Cidade em Portugal: Uma geografia Urbana. Coleção Cidade em Questão/8. Porto: Edições Afrontamento, 1992, p. 83.

${ }^{50}$ Idem,ibidem, p. 84.
} 
manuelino. Após o terremoto de 1755, cuja área incendiada está demarcada (FIGURA-4), e cuja descrição lemos nos textos (FIGURA-5), a reconstrução da Baixa lisboeta seguiu orientação segundo rigor militar e funcionalidade, respeitados os conceitos de saúde pública. Dentre eles, ar fresco e luz aparecem como valores novos, ruas mais largas e praças. Há busca de formosura de conjunto e simetria em portas, janelas e alturas. $\mathrm{O}$ engenheiro-mor do reino Manuel da Maia é encarregado pelo Marquês de Pombal, o poderoso ministro de D. José, a estudar uma solução para a cidade em ruínas. Das três hipóteses apresentadas foi escolhido o projeto de Eugénio dos Santos (FIGURA-6), inovador, que bem acordava com o pensamento político de Pombal. Prático e racional, o plano contava com malha ortogonal de quarteirões retangulares, com praças quadrangulares, edificações estruturadas em "gaiolas", com elementos de madeira travados entre si e em separado da argamassa, estuque e cantaria, por segurança e medida de prevenção a novos abalos sísmicos. Deveriam ser seguidos o projeto-tipo das fachadas, as normas de construção e a organização interior. Rede de esgoto, janelas com vidro e pias de cozinha obrigatórias são alguns exemplos.

Em continuidade, a vida portuguesa da primeira metade do século XIX é bastante conturbada. As invasões francesas contribuem para a desorganização econômica e, politicamente, Portugal, cada vez mais sujeito aos interesses ingleses, do ponto de vista da técnica, atrasa-se em relação a outros países europeus. As manufaturas haviam sido quase todas desativadas. A Baixa pombalina não era considerada zona chique no século XIX, sendo preterida pelo Chiado, onde se construía a Estação da Ferrovia, que daria origem à Avenida da Estação e aos bairros modernos, com palacetes da alta burguesia.

Ao estilo vitoriano, no final de 80, iniciou-se a planificação do Bairro Alto, para onde se mudariam aqueles que consideravam a Baixa demasiado buliçosa e acanhada. A cidade, a exemplo de Paris, adere aos boulevards, jardins. O Estrela, desenhado em 1842, e 
o Passeio Público, cercado por grade de ferro, depois da reforma por que passou em 1835, eram partes integrantes da vida social de Lisboa. Iniciam-se, a seguir, as obras da Av. da Liberdade e do Parque Eduardo VII, inicialmente chamado Liberdade. Arranjam-se, também, pequenos jardins municipais, por todo lado, com cercas de buxo e exíguos canteiros com flores. Nesse contexto, a árvore se distingue como elemento ornamental, cujo significado é diminuir a distância da natureza, e representa a preocupação em minorar os efeitos da poluição. Com o Liberalismo e a extinção das ordens religiosas, ocorrem alterações na titularidade e ocupação dos imóveis. Edifícios conventuais entram na posse do Estado, que aí instala prisões, quartéis, escolas, museus, repartições públicas, hospitais. No último quartel do século XIX, período decisivo para o urbanismo de Lisboa, há forte crescimento populacional e aumento de área do município. Aparecem fábricas, oficinas, transportes coletivos, grandes negócios e respectivas riquezas. O desenvolvimento urbano volta-se para o norte, dando as costas para o rio, como é vulgar dizer-se. Surgem, também, as primeiras habitações operárias em Lisboa, de pessoas que vêm do campo à cidade em busca de trabalho industrial. Vítimas da especulação imobiliária, vão acumular-se em edificações precárias nas zonas de baixa salubridade. Na época de Cesário, portanto, Lisboa se encontrava em grandes transformações físicas e sociais, as quais não escaparam ao olhar sensível do poeta, que não só as descreve detalhadamente, como expressa o sentimento delas decorrente, em seus versos. É o caso dos poemas onde predomina o cenário urbano. Por exemplo:

Dez horas da manhã; os transparentes

Matizam uma casa apalaçada;

Pelos jardins estancam-se as nascentes,

E fere a vista, com brancuras quentes,

A larga rua macadamizada. (Num Bairro Moderno, E.1-2) 
Faz frio. Mas, depois duns dias de aguaceiros,

Vibra uma imensa claridade crua.

De cócoras, em linha, os calceteiros,

Com lentidão, terrosos e grosseiros,

Calçam de lado a lado a longa rua. (Cristalizações, E.1-2)

Nas nossas ruas, ao anoitecer,

Há tal soturnidade, há tal melancolia,

Que as sombras, o bulício do Tejo, a maresia

Despertam um desejo absurdo de sofrer. (OSO, E.1-2)

Nos três fragmentos de poema acima transcritos, a supremacia do mundo exterior e da materialidade dos objetos urbanos impõe o real concreto. No primeiro, através da situação espaciotemporal "dez horas da manhã", das cenas descritas no exterior e interior das “casas apalaçadas”, “pelos jardins”, "na rua macadamizada”, “os transparentes”, “as persianas”, “os quartos estucados', “papéis pintados”, “porcelanas', que conotam o luxo e o ócio nos bairros aburguesados. No segundo, em oposição a isso, a dureza do trabalho dos calceteiros, a longa rua e a casaria, trazem aos olhos do leitor detalhes da cidade em transformação física e a exploração da força de trabalho. E, no terceiro, o anoitecer nas ruas da cidade, o rio, o gás, os edifícios, a turba despertam a melancolia e o desejo de sofrer expresso pelo sujeito lírico. Nos três poemas o cotidiano é expresso em tempo presente, revelando o espaço urbano percorrido pelo poeta que se empenha em captar o real em sua deambulação, porém sua visão subjetiva e seu sentimento decorrente, são marcantes, como podemos ver nas expressões: "fere a vista", "tal soturnidade', "tal melancolia". Os verbos dos poemas citados ora traduzem movimento "matizam", "abriram-se", "reluzem"; ora inércia: “estancam-se”, "repousam", "parece”, criando um ritmo pulsante; ao passo que as locuções adverbiais refletem estados e situações variadas: “dez horas da manhã”, "com lentidão","ao anoitecer". Os substantivos denotam elementos do mundo urbano, recorrentes na obra de Cesário:“rua", "gás”, “casaria”, "turba”, os adjetivos conotam a valoração a eles 
atribuída pelo sujeito lírico; "casa apalaçada", "molhada casaria" e "cor monótona e londrina" são exemplos de descrição detalhada que traz a cidade aos olhos do leitor, através das imagens físicas e sentimentais que o sujeito poético cria.

Embora não seja o caso de uma análise topográfica minuciosa, neste momento, vale dizer que, através dos elementos espaciais descritos pelo sujeito lírico em $O$ Sentimento dum Ocidental, pode-se ter uma ideia do percurso enquanto que aleatório "a vagar sem rumo". Tendo iniciado seu caminhar, ao anoitecer, pelo Chiado, o sujeito lírico desce para a Ribeira, retorna ao Chiado, passa pelo Largo de Camões e, pela Baixa, segue rumo ao Castelo de São Jorge, terminando seu percurso na Alfama, na madrugada do dia seguinte. Seus passos percorrem tanto a parte da cidade medieval, de becos e ruelas tortuosas que causam surpresa a cada curva, quanto a parte nova da capital, reconstruída a mando do Marquês de Pombal, após o terremoto de 1755, de ruas retas e avenidas largas (FIGURA7). Opõe-se aqui a emoção angustiante do traçado medieval à razão geométrica da cidade pombalina. Lá são evocados pela memória o enriquecimento de Portugal com o comércio gerado pelas Grandes Navegações e o processo de Colonização do além-mar, entre outros triunfos históricos, bem como as desgraças representadas pela Inquisição, o terremoto, a febre amarela, o cólera. Aqui são evocados o saneamento das avenidas, a iluminação e o transporte trazidos pela técnica, bem como o estrangeirismo da moda e dos costumes, que provocam o sentimento opressivo e de o solidão, situando-se o sujeito lírico entre ambos. Segundo Milton Santos: "o espaço não pode ser estudado como se os objetos materiais que formam a paisagem trouxessem neles mesmos sua própria explicação. Isso seria adotar uma metodologia puramente formal, espacista, ignorando os processos que ocasionaram as formas." 51 Depreendemos daí, portanto, a necessidade de incluir a noção temporal do processo histórico na leitura do espaço.

\footnotetext{
${ }^{51}$ SANTOS, Milton. 2007. Op. Cit., p. 58
} 
O percurso descrito no poema, ora em foco, ora em perspectiva, permite uma visão das relações espaciotemporais na totalidade da cidade. Nesse contexto, a presença da modernidade se faz sentir pelo uso da técnica industrial, recém-chegada à metrópole portuguesa, no século XIX, que o ato de caminhar e de escrever presentifica e perpetua num continuum que possibilita ao leitor tanto uma reflexão sobre aquele mundo, quanto sobre o mundo atual. Isso permite cotejá-los no que têm de próximo e distante, para melhor compreensão de ambos.

No poema OSO o espaço vai sendo construído a partir do olhar do sujeito lírico, sobre formas relacionadas à cidade e ao campo, que influenciam as determinações sociais do presente, levando em conta as heranças do passado. Por exemplo: "Duas igrejas, num saudoso largo, / Lançam a nódoa negra e fúnebre do clero;/ Nelas esfumo um ermo inquisidor severo, / Assim que pela História eu me aventuro e alargo.” (II-4). Sem deixar de reconhecer a contribuição que a Igreja emprestou à ética, à cultura, à arte, à história do mundo, o autor condena, com elegância, os abusos da Inquisição. Tal dinâmica presentepassado se repete em outros poemas, como é o caso de Provincianas: “Olá! Bons dias! Em março / Que mocetona e que jovem / A terra! Que amor esparso / Correm os trigos, que se movem / Às vagas dum verde garço.” (E.1). A idéia do tempo cíclico da natureza é dada pela expressão "Bons dias!", indicativa do período matutino; pelo substantivo "março", que traz a conotação da nova estação do ano, e pelas expressões nominais “jovem a terra e verde garço", que reforçam o sentido da renovação trazido pela primavera, transformando a paisagem física e sentimental do sujeito lírico. As exclamações denotam seu entusiasmo ante a estação presente, criadora, ao mesmo tempo em que sugerem o final do inverno, estação que deixou grãos e sementes.

Daí, o breve estudo da topografia lisboeta permitir um diálogo com a visão que o sujeito tem do espaço. Em poucas palavras, o traçado urbano de Lisboa, a primeira cidade 
em escala da Europa, após o terremoto de $1^{\mathrm{o}}$ de novembro de 1755 , foi planejado e executado a mando do Marquês de Pombal, para que rapidamente se reconstruísse o espaço destruído por aquele abalo sísmico, que foi seguido de maremoto (FIGURA-8) e de um incêndio que durou vários dias, destruindo parcialmente a cidade antiga, da qual podemos ter uma idéia a partir de um painel de azulejos da época (FIGURA-9). As ruas tortuosas da Lisboa medieval, em algumas áreas, foram reconstruídas com base em um plano racional de traçado geométrico, que seguiam um padrão construtivo de casarões, janelas, fachadas, chaminés, azulejos iguais, visando à rapidez de se reconstruir a cidade que, como estava, era presa fácil de outros impérios. Alguns bairros foram totalmente reformulados e, outros, menos prejudicados, permaneceram como eram. Caso destes últimos é a Alfama, bairro ao lado do Castelo de São Jorge, cujas vielas à direita deram origem à cidade. Alguns edifícios permaneceram em escombros, como o Grande Teatro de Ópera, inaugurado aquele ano por D. João V, que nunca foi reconstruído. Já o antigo Terreiro do Paço, no reinado de D. José I, passa, depois de reconstruído, a ser a atual Praça do Comércio, evidenciando a vocação da cidade portuária do final do século XIX, num outro momento histórico, o liberal. Sobre a Revolução Liberal de 1820 lê-se:

Progressos agrícolas e técnicos, caminhos de ferro, abertura de novos mercados, desarmonização, promulgação do Código Civil, sufrágio censitário, desaparecimento de direitos senhoriais... quantas modificações não ocorreram em Portugal ao longo do século XIX desde o triunfo da revolução liberal de 1820! As suas repercussões são na sociedade portuguesa - evolução, comportamentos e atitudes dos diversos grupos sociais. - são ainda, no estado actual da investigação histórica no nosso país, difíceis de apreciar em toda a sua extensão. ${ }^{52}$

\footnotetext{
${ }^{52}$ VAQUINHAS, Irene M. e Rui Cascão História de Portugal. Org. José Mattoso.Vol. V. O Liberalismo (1807-1890) e Evolução da sociedade em Portugal: a lenta e complexa afirmação de uma civilização burguesa. Lisboa: Editorial Estampa, 1975, p.441.
} 
Isso nos leva a refletir sobre o processo de metropolização oitocentista em cidades européias periféricas do então chamado mundo moderno, industrializado, da época, como Londres e Paris; e cotejá-lo com nosso mundo do presente, globalizado pela técnica, mas ainda de modernidade incompleta pelas injustiças socioespaciais que comporta. Nas palavras de Milton Santos, A chamada "aldeia global” não existe. É apenas uma construção, pois falta sentido a esse conceito. ${ }^{53}$

No poema, a Lisboa do século XIX é trazida aos olhos do leitor de OSO em toda sua complexidade dinâmica, matizes realistas e profundidade histórico-emocional pelo sujeito lírico em contínuo diálogo com o sujeito observador, a partir das relações espaciotemporais. Se o herói épico do passado era nacional, ou seja, o nobre ou burguês que empreendia conquistas marítimas para Portugal renascentista, no presente lírico este herói é o indivíduo comum que vive no cotidiano sua epopéia de sobrevivência e busca sua identidade perdida em uma cidade moderna, em transformação. Ao expressar sua angústia em relação ao meio, o sujeito poético revela objetos e situações da realidade exterior (espaço físico) captados pelos sentidos e transmutados em sentimento subjetivo, que é expresso em sua poesia como um todo. O espaço físico e o espaço da emoção, através das palavras, dialogam no processo criativo dos poemas, como verificaremos mais adiante, no capítulo dois.

\section{O SUJEITO E O TEMPO}

No poema OSO o sujeito poético, movido pela angústia existencial, perambula pelas ruas da cidade, enquanto indivíduo e enquanto cidadão, do anoitecer ao amanhecer do dia seguinte. Em seu percurso aleatório e noite adentro, depara-se com elementos espaciais do seu cotidiano presente (século XIX), os quais atualizam diferentes experiências e

\footnotetext{
${ }^{53}$ VEJA. São Paulo. Entrevista: Milton de Almeida Santos. 16 de novembro de 1994, pp. 7 a 10.
} 
acontecimentos do passado da nação portuguesa, que vão do heroísmo, da esperança, das Grandes Navegações ao terror da Inquisição. Enquanto perambula pelas ruas da cidade, o sujeito vai captando a realidade lisboeta através dos sentidos e com aguçada percepção de mundo a recria através de palavras. Embora nesse processo estejam envolvidos todos os sentidos do sujeito, há predominância da visão e do olhar na poesia de Cesário. Acerca da diferença existente entre visão e olhar, Lacan explicita: “O olhar só se nos apresenta na forma de uma estranha contingência, simbólica do que encontramos no horizonte e como ponto de chegada de nossa experiência, isto é, a falta constitutiva da angústia da castração." ${ }^{, 54}$ E mais adiante: "Em nossa relação às coisas, tal como constituída pela via da visão e ordenada nas figuras da representação, algo escorrega, passa, se transmite, de piso para piso, para ser sempre nisso em certo grau elidido - é isso que se chama o olhar.“ ${ }^{55}$. Para fins de análise, adotamos a fragmentação do sujeito poético em: sujeito-observador, ao que se refere a olho, e sujeito-lírico, ao que se refere a olhar, evidenciando com isso a problemática que contrapõe a reprodução fiel da realidade exterior em sua objetividade meramente descritiva à subjetividade lírica expressa nos poemas através das imagens poéticas, que resgatam o tempo passado, no presente, por sobreposição. Acerca do tempo, Milton Santos pondera: "A noção de tempo é fundamental. A sociedade é atual, mas a paisagem, pelas suas formas, é composta de atualidades de hoje e do passado.” E, em seguida, adverte: “A noção de escala é igualmente importante, pois, se o espaço é total, a paisagem não o é. Não se pode falar de paisagem total, pois o processo social de produção é especialmente seletivo." ${ }^{, 56}$. Ambas as noções de tempo e de escala contribuem significativamente para a interpretação da obra poética de Cesário, como a estrofe que se segue exemplifica bem, na medida em que evoca as "crônicas navais" e a tudo ressuscita:

\footnotetext{
${ }^{54}$ LACAN, Jacques. O Seminário, Livro 11: Os quatro conceitos fundamentais da psicanálise (1964). Trad. M.G. Magno. $2^{\mathrm{a}}$ edição. Rio de Janeiro: Jorge Zahar Ed., 1998, p.74.

${ }^{55}$ Idem, ibidem, p.74.

${ }^{56}$ Idem, ibidem, p. 60.
} 
“E evoco, então, as crônicas navais; / Mouros, baixéis, heróis, tudo ressuscitado!/ Luta Camões no Sul, salvando um livro, a nado! / Singram soberbas naus que eu não verei jamais!" (OSO, I-6)

Concebido inicialmente para homenagear Camões, o poema OSO remete, até certo ponto, ao épico e a sua obra “Os Lusíadas”, num contexto muito posterior e diferente, mas originado nele, num outro momento do desenvolvimento do "projeto iluminista", do progresso, do sonho do futuro, da esperança daquele momento que, no entanto, longe de confirmar sua plenitude, revela a angústia existencial.

Nesta inter-relação entre a objetividade do que foi (do que temos notícias) e do que é (vivência e criação) para o sujeito poético, suas emoções, imaginação e memória, bem como as deformações propiciadas por elas, e pela ilusão de ótica, pela noite, entre outras coisas, instaura-se um diálogo onde outro espaço-tempo se insinua, ainda que sem forma acabada, com características simultaneamente semelhantes e diferentes, que revela ao leitor a constituição do sujeito lírico em busca da identidade. Por exemplo, nos versos: “Ou erro pelo cais a que se atracam botes." (I-5),/ "Assim que pela história me aventuro e alargo" (II-4), "E, eu, que medito um livro que exacerbe," (III-5), "Buscasse e conseguisse a perfeição das coisas" (IV-4), em que os verbos na primeira pessoa do singular "erro", “aventuro", "medito" e "buscasse" denotam tal esforço subjetivo.

Para reconhecimento e interpretação do sujeito lírico, consideramos o seguinte:

Em síntese, o "eu poético" define-se como um "eu" que se autoexpressa para se conhecer e para se comunicar ao leitor. [...] tentar compreender o fenômeno poético no âmbito da voz que fala no poema, que fala para exprimir-se e comunicar-se; que fala em seu próprio nome, embora pretenda ser universalmente ouvida e, quiçá, espelhar o sentimento vago e inconfortável que agita o leitor de poesia. ${ }^{57}$.

\footnotetext{
${ }^{57}$ MASSAUD, Moisés. A Criação Literária: Poesia. $16^{\mathrm{a}}$ ed. São Paulo: Cultrix, 2003, p.146.
} 
A partir daí, analisamos o sujeito lírico de OSO ao longo das quatro partes do poema, que, embora independentes graficamente, formam no conjunto quatro movimentos de uma mesma sinfonia que tem por tema o cotidiano da Lisboa oitocentista, assim descritos por Helder Macedo em sua simetria estrutural e funcional:

A progressão da noite, desde o crepúsculo e o acender das luzes, até a completa escuridão das "horas mortas", é acompanhada, num complexo contraponto, por um correspondente aprofundamento dos sentimentos e percepções do caminhante solitário nas ruas da cidade. O melancólico “desejo absurdo de sofrer” despertado pelo anoitecer é justaposto com uma nostálgica evocação visionária do passado; a mórbida exacerbação da angústia ao acender das luzes é justaposta com as alucinações febris de um presente fantasmagórico; a intensificada amargura provocada pela crescente escuridão é justaposta com a presença espectral dos seres reais que se movem na cidade; finalmente, na escuridão total das horas mortas, a evocação ansiosa de um futuro gerado pela própria noite, como a sua necessária negação num novo dia, é justaposta com a culminante visão desesperada da dor humana como um sinistro mar de fel em busca dos seus amplos horizontes bloqueados. ${ }^{58}$

Coincidindo com o início da Parte I do poema o percurso do sujeito lírico começa “ao anoitecer", horário em que - ironicamente - a comunidade católica religiosa se organiza em torno do ritual da Ave-Maria, e, contrariamente a isso, mostra-se um ser solitário, tomado pela angústia, que deambula pelas ruas familiares, "as nossas ruas" (I-1), sensível aos múltiplos impactos sensoriais que a cidade lhe oferece. À medida que as sombras se acentuam, com o passar das horas marcadas pelo decorrer do tempo cronológico, dificultando a visão clara das coisas, os ruídos abafados e o cheiro a maresia se sobressaem, alcançando o sujeito lírico, que reage psicologicamente a isso, com "um desejo absurdo de sofrer" (I-4). Conforme as sombras se acentuam, outros sentidos vão se

\footnotetext{
${ }^{58}$ MACEDO, Helder. Nós: uma leitura de Cesário Verde. Lisboa: Editorial Presença, 1999, p.166.
} 
aguçando e os ruídos abafados "ao fundo" (I-3), o cheiro a maresia exalado pelo rio, bem como o do gás extravasado pelos canos "enjoa e perturba". Na relação sujeito-mundo, longe de haver um sentimento de continuidade, há uma contrariedade entre sujeito lírico e cidade que o sentimento de "soturnidade" e "melancolia" revela, em oposição ao bem-estar que a natureza campestre oferece, como é o caso em De Verão: "No campo; eu acho nele a musa que me anima;/ A claridade, a robustez, acção.” (E.1), só para exemplificar, posto que a contraposição cidade-campo na obra cesariana é tema que exploraremos adiante.

A crescente escuridão do descer da noite vem como uma barreira opressiva enclausurar de cima a cidade, a qual, aos olhos do sujeito lírico, torna-se massa irregular de coisas e seres indistintamente fundidos, como se lê nos versos: "E os edifícios, com as chaminés e a turba/Toldam-se duma cor monótona e londrina" (II-3-4).

Diferentemente de Baudelaire "que não descreve nem a população nem a cidade. $\mathrm{E}$ é exatamente esta renúncia que lhe permitiu evocar uma na imagem da outra. A sua multidão é sempre a das metrópoles; a sua Paris é sempre superpovoada." ${ }^{59}$, o sujeito lírico de $O$ Sentimento dum Ocidental coloca-se em contrariedade à cidade e partilha da "Dor humana" de seus cidadãos, principalmente dos trabalhadores e dos miseráveis: "O que me rodeia é o que me preocupa", segreda o poeta em carta a Silva Pinto. ${ }^{60}$ A associação a Londres, pela cor sombria, expande a imagem da grande capital mercantil industrializada e se contrapõe à opressiva Lisboa do século XIX, explorada pela sociedade industrial, onde a multidão de pessoas não passa de uma "turba", à voz do sujeito poético, de timbre realista. Aqui, também, a oposição do campo se faz presente em De Verão: "Que aldeias tão lavadas! Bons ares! Boa luz! Bons alimentos! Olha: os saloios vivos, corpulentos," (E.4), expressa, principalmente, pelos adjetivos "lavadas, "Boa", "Bons", "vivos", corpulentos",

\footnotetext{
${ }^{59}$ BENJAMIN, Walter. Sobre Alguns Temas em Baudelaire, em W. Benjamin et alii, Textos Escolhidas. $2^{a}$ ed. São Paulo: Abril Cultural, 1983 (Os Pensadores).. p. 37.

${ }^{60}$ Conforme se lê em nota referente à epígrafe do terceiro capítulo.
} 
que conotam claridade e o vigor, em contrariedade à cor sombria da opressiva Lisboa de $O$ Sentimento dum Ocidental.

O efeito aprisionador da cidade, intensificado pelo escurecer (tempo), pelo cheiro do gás extravasado que se alastra (espaço) e pelo movimento dos caros "de aluguer" que levam “à via-férrea os que se vão. Felizes!", provoca no sujeito lírico uma ânsia de fugir para outro lugar (espaço), onde a totalidade do mundo extrapola a fragmentação das cidades. Entretanto a realidade do presente o chama de volta ao cotidiano. Em seu percurso solitário, as atividades crepusculares dos carpinteiros surgem ante seus olhos como "morcegos ao cair das badaladas", ao mesmo tempo em que, emergindo dos "becos" e "boqueirões" do cais, "calafates" abatidos pelo cansaço e escurecidos de fuligem retornam do trabalho em grupos. As descrições, acentuadamente naturalistas, rebaixam o ser humano à condição de animal, como é o caso da conotação de criatura das sombras em "morcegos". Embora nefastos, eles são alados e capacitados a ver no escuro, como os obreiros.

As pequenas embarcações ancoradas no rio voltam a despertar no sujeito lírico a ânsia de fuga (no tempo), e ele ressuscita o passado heróico: da memória, "crônicas navais"; da história, "Mouros, baixeis, heróis, tudo ressuscitado!”; no presente imaginário, “Os Lusíadas": "Luta Camões no sul, salvando um livro, a nado!”. Lemos em H. Macedo:

De par com seu valor metafórico, a referência a Camões serve também para tornar o todo do poema, onde funcionalmente se integra na homenagem que Cesário lhe quis prestar, ao escrevê-lo: a seguir, o poema, originalmente publicado numa folha intitulada Portugal a Camões, editada pelo "Jornal de Viagens", em 10 de Junho de 1880, foi escrito como uma contribuição para as comemorações do tricentenário da morte de Camões. ${ }^{61}$

Na quinta estrofe, exatamente a do meio da Parte I do poema, o sujeito lírico momentaneamente sai da atmosfera opressiva da cidade e busca um curto respiro no

\footnotetext{
${ }^{61}$ MACEDO, op. cit., p. 172.
} 
passado de "soberbas naus" que a dupla negativa "não verei jamais" traz de volta a realidade do presente no poema.

Ao deparar-se com elementos espaciais como "couraçado inglês" e "hotéis da moda" que representam simbolicamente a alta-burguesia citadina, o sujeito poético passa a descrever várias personagens que começam a surgir ante seus olhos como figuras degeneradas em atividades vagas e vazias da vida burguesa citadina: "Num trem de praça arengam dois dentistas; / Um trôpego arlequim braceja numas andas / Os querubins do lar flutuam nas varandas; / Às portas, em cabelo, enfadam-se os lojistas!” (Parte I-8). E, contrastando com isso, sua visão capta o cinético e o visual tableau vivant das massas trabalhadoras que "vazam" dos "arsenais" e "oficinas", como que a preparar a entrada triunfal das "varinas". Acerca deste episódio, vários estudiosos se manifestaram, dentre eles, Jorge de Sena: “A “épica” entrada das varinas não tem par nem mesmo em Camões. "62, atribuindo-lhe a dimensão heróica do passado, no cotidiano do presente; o que Helder Macedo reforça ao ponderar: “A associação implícita entre essas mulheres "hercúleas” e o mundo épico das "crônicas navais" é subtilmente reforçada na relação, que dinamicamente aproxima o passado e o presente, entre a imagem do naufrágio de Camões: "no Sul, salvando um livro, a nado", com a imagem dos filhos das varinas "que depois naufragam nas tormentas" (I-10) ${ }^{63}$. Ante o quadro de miséria da vida dessas mulheres, "Descalças! Nas descargas de carvão", ou seja, usadas como animais de carga até a noite, quando se amontoam nos bairros infectados, que simbolizam a degradação material, o sujeito poético manifesta sua revolta social, reforçada pelo ponto de exclamação: "E o peixe podre gera focos de infecção!”

Como se lê no fragmento a seguir, o contraste das varinas com "querubins do lar", no poema, é revelador da inversão de valores onde o componente romântico de "lânguidos"

\footnotetext{
${ }^{62}$ SENA, Jorge de. A Linguagem de Cesário Verde. ESTRADA LARGA I. Porto: Porto Editora, 1958, p. 412.

${ }^{63}$ MACEDO, Op. Cit. , p.172.
} 
se opõe ao realista de "ancas opulentas". Se aquele está associado ao modelo feminino do ócio e da fragilidade da burguesa do Romantismo, este se associa ao modelo de força de trabalho das mulheres do povo, na luta por sobrevivência, inscrevendo o poema na temática da estética realista da segunda metade do século XIX:

[...] o contraste entre a visão etérea dos lânguidos "querubins do lar" com a descrição da firmeza opulenta das varinas - as mães dos náufragos futuros que, no entanto são os perpetuadores e os herdeiros da aventura do passado - constitui um comentário poderoso, porque objectivamente representado na realidade social observada, sobre a inversão dos valores naturais nas situações respectivas das suas classes sociais. ${ }^{64}$

Tal característica também é observada no poema Nós, em que a doença da irmã, prenunciada como "alvor romântico de miss" (E.42) se opõe ao "pano das camponesas" (E.43), vigorosas e plebéias. (E.42).

No segundo movimento do poema, ao acender das luzes a gás nas ruas, acentua-se no sujeito lírico o sentimento de melancolia a ponto de ele suspeitar de um mal físico, como expressam os versos: "E eu desconfio, até, de um aneurisma / Tão mórbido me sinto, ao acender das luzes; / À vista das prisões, da velha Sé, das Cruzes, / Chora-me o coração que se enche e que se abisma.” (OSO, II-2), em oposição a; “Ah! Que aspectos benignos e rurais / Nesta localidade tudo tinha. / Ao ires, com o banco de palhinha, / para a sombra que faz nos parreirais!” (Nós, E.31).

\footnotetext{
${ }^{64}$ Idem, ibidem, p. 172.
} 


\section{O SUJEITO E O MUNDO}

No poema OSO, durante o percurso solitário pelas ruas da cidade, à luz fantasmagórica da iluminação a gás, a percepção sensorial do sujeito lírico funde-se à projeção psicológica da imaginação, assim que ele se aventura e alarga pela história. $\mathrm{O}$ sentimento individual passa a expressar o sentimento da nação através dos elementos espaciotemporais que representam as instituições urbanas: os monumentos e as tragédias, sem olvidar do populesco. Assim, o épico de outrora, o som às grades nas cadeias, a visão do aljube, das prisões e igrejas representam o poder; a parte que abateu o terremoto e as epidemias que assolaram Lisboa, a tragédia; e as varinas representam o populesco, dando continuidade do passado no presente. Aqueles o fazem sofrer: "Chora-me o coração que se enche e que se abisma." (II-2); e estas, sonhar: "Ah! Como a raça ruiva do porvir", pois alguns navegantes eram filhos do povo, das varinas. A memória das torturas da Inquisição, das epidemias de febre amarela e cólera que dizimaram a população provocam o sentimento de tristeza, que é projetado na cidade em que convivem, lado a lado, um palácio iluminado, símbolo da riqueza, do poder estabelecido, e um casebre, símbolo da extrema pobreza. Às formas de repressão do passado, simbolizadas pelos soldados, seguem-se as do presente lírico: "Partem patrulhas de cavalaria / Dos arcos dos quartéis que foram já conventos;" (OSO, II-9). E ante a visão do presente que resgata a memória da cidade, o sujeito poético expressa o sentimento de nação pela metonímia da cidade de Lisboa: "Triste cidade! Eu temo que me avives uma paixão defunta!” (idem); em oposição ao campo, "No país montanhoso, com relevo!” (Nós, E.35), onde o substantivo “país” evidencia o sentido.

Simultaneamente ao mundo do baixo sugerido pela perseguição religiosa e prisões, o sujeito lírico percebe um mundo sublime "Com bancos de namoro e exíguas pimenteiras", onde "Brônzeo, monumental, de proporções guerreiras, / Um épico de 
outrora ascende, num pilar!” (II-6), representa sua mais alta expressão. Embora o namoro remeta ao mundo individual burguês, ele sugere o amor em sentido platônico mais elevado, e, nesse sentido, provoca no leitor um sentimento que mais se aproxima do amor sublime. Embora o épico se apresente ao lado do individual e burguês representado por "bancos de namoro", e, neste sentido, se apresente rebaixado, vulgarizado, as expressões "brônzeo" (de metal nobre), "monumental" (de grandeza histórica), "de proporções guerreiras" remetem ao mundo superior de conotação nacional, de renúncia ao individual em favor de uma causa coletiva. Sublime, também, é a visão que ele tem da lua, a qual remete à natureza, que, ao contrário da visão fragmentada dos edifícios que "A espaços, iluminam-se os andares,/ E as tascas, os cafés, as tendas, os estancos", lembra a totalidade do "circo e os jogos malabares”. (II-3). Em ambos os casos, a expressão artística associada à natureza, como designam os substantivos concretos "pimenteiras" e "lua", se contrapõe à realidade grotesca da nação, que se deixa levar pela idéia de "progresso" materialista, como forma de resgatar a origem dupla do ser humano: pés fincados na terra e espírito elevado aos céus, entendido como transcendente à matéria, de ordem espiritual. Aqui o sujeito não se deixando enganar, reage: "Eleva-me a quimera azul de transmigrar." (IV-1)

Os lampiões distantes, que "alvejam" as elegantes do mundo artificial da moda, contrapõem-se às tradicionais costureiras e floristas que "enlutam" o sujeito, solidário a elas, que protesta contra a sobrecarga de trabalho que lhes é imposta:

[...] o notável poder sincrético do oxímoro nas formas verbais justapostas enlutam-me" - que prolonga a imagística de morte dos versos anteriores - e "alvejando" - com toda a sua riqueza de sugestões luminosas - dá a esta passagem uma extraordinária tensão dinâmica." O contraponto entre as figuras (elegante e costureiras/floristas) expressa a consciência revoltada do sujeito lírico, que solitário entra na brasserie e observa que, 
contrariamente à sua solidão, "às mesas de emigrados/ Joga-se, alegremente e ao gás o dominó!" 65

O contraste irônico nesta última estrofe da Parte II do poema ressalta a inquietação do sujeito lírico pertinente à nação portuguesa e a aparente despreocupação dos estrangeiros foragidos que se dedicam ao lúdico, que o ponto de exclamação final reforça. Nesse sentido, Jorge Luiz Antonio aponta: “A visão particular (ora eu, ora nós, ora ele) vai ampliando o círculo de ação (simbolização da realidade por meio das palavras) e torna-se geral, se universaliza num sentimento nacional e se torna o sentimento de um ocidental." 66 Diferentemente do Oriente, Ocidente era compreendido como mundo industrializado, da técnica e do progresso, no século XIX. ${ }^{67}$.

O movimento de saída do sujeito lírico da brasserie dá início à terceira parte do poema. Intensificado pela noite, o sentimento de opressão da cidade aumenta: "E saio. A noite pesa, esmaga." A atmosfera de alucinação funde a realidade externa da cidade às impressões que dela tem o sujeito lírico: "Ó moles hospitais! Sai das embocaduras / Um sopro que arrepia os ombros quase nus. // Cercam-me as lojas, tépidas. Eu penso / Ver círios laterais, ver filas de capelas," (III-2) são exemplos da alucinação que consome o sujeito lírico, contribuindo para sua despersonalização ante a cidade que reflete o caos da nação. Aqui, o autor explora a funcionalidade da imagem dos candeeiros que iluminavam algumas poucas ruas de Lisboa e o efeito literário deles "círios", através de uma sobreposição de espaços: real (rua) e psicológico (catedral). O espaço físico interage com o espaço emocional humano. Ironicamente as prostitutas que se "arrastam" nos passeios são associadas aos "moles" hospitais, e o comércio "lojas tépidas" à igreja "círios de capelas", conotando a decadência ético-moral que mina a capital da nação, que a metáfora mulher

\footnotetext{
${ }^{65}$ ANTONIO, Jorge Luiz. Cores, Forma, Luz, Movimento: A Poesia de Cesário Verde. São Paulo: Musa Editora/FAPESP, 2002, pp. 264-265.

${ }^{66}$ Idem, ibidem, pp. 264-265.

${ }^{67}$ A questão Oriente/Ocidente no século XIX merece estudo aprofundado em uma outra ocasião, que não esta, por não ser ela, aqui, o principal enfoque do trabalho.
} 
representa na obra como um todo. Por exemplo, os poemas Vaidosa, Esplêndida e Frígida, nos quais a mulher citadina arrasta o sujeito para a morte, que os versos a seguir bem elucidam: "E eu vou acompanhando-a, corcovado, / No trottoir, como um doido, em convulsões,/ Febril, de colarinho amarrotado," (Esplêndida, E.7). A diversidade dos perfis femininos, encontrada, principalmente, nos poemas Deslumbramentos, A Débil e Manhãs Brumosas, evidencia a atração que o sujeito lírico sente pelo tipo de mulher nórdica, vamp e aristocrática, a senhora, enfim, a quem rende louvores e ameaças: "Mas cuidado, milady, não se afoite, / Que hão-de acabar os bárbaros reais; /E os povos humilhados, pela noite,/ Para vingança aguçam os punhais.” (Deslumbramentos, E.9), com a lucidez socialista, que é peculiar a Cesário.

Somando-se a isso os versos: “As burguesinhas do catolicismo / Resvalam pelo chão minado pelos canos, / E lembram-me, ao chorar doente dos pianos, / As freiras que os jejuns matavam de histerismo.” (OSO, III-3) exemplificam o anticlericalismo de Cesário, em moldes realistas, sem, contudo, espelhar-se no exemplo cáustico dos romances mais sarcásticos de Eça.

Os detalhes do cotidiano descritos pelo sujeito poético ao longo do percurso adquirem tons impressionistas, sem contornos nítidos, ambíguos, revelando a falta da identidade da nação que se confunde com os hábitos e moda estrangeira. Nesse ambiente, os "xales com debuxo", a "traine que imita um leque antigo", os "mecklemburgueses", os "tecidos estrangeiros" chamam a atenção dos comerciantes; ao passo que "um homenzinho idoso", a esmolar nas esquinas, desperta a compaixão do sujeito lírico: "Dó da miséria! Compaixão de mim! - / E, nas esquinas, calvo, eterno, sem repouso, / Pede-nos sempre esmola um homenzinho idoso, / Meu velho professor nas aulas de latim! “ Nesse sentido, cabe, a título de enriquecer a análise, o comentário que se segue: 
A caracterização do mendigo como "eterno, sem repouso" vem acentuar no poema um elemento simbólico já subliminalmente sugerido na descrição do ambiente: o percurso do poeta pelas ruas nocturnas da cidade é também uma viagem simbólica por um mundo de fantasmas onde, como Dante, no Inferno, encontra o seu "velho professor". Mas em Cesário, como sempre, o símbolo está na própria realidade objectiva, e neste seu encontro há uma alusão literal ausente do encontro imaginário de Dante deambulando com Virgílio no Inferno: no tempo de Cesário, havia efectivamente um professor de Latim - que acabou a vida a esmolar nas ruas de Lisboa. ${ }^{68}$

Por outro lado, os ofícios manuais como "Um cuteleiro, de avental, ao torno, / Um forjador maneja um malho, rubramente, / E de uma padaria exala-se ainda quente, / Um cheiro salutar e honesto a pão de forno". que conotam espaço de iluminação e elevação moral pelas imagens de luz e calor que evocam, em contraposição à doença e hipocrisia da sociedade, animam momentaneamente o sujeito poético que enuncia a escrita como forma de recompor a totalidade fragmentada: "E eu, que medito um livro que exacerbe, / Quisera que o real e a análise mo dessem," (OSO, III-5).

As composições poéticas de Cesário anteriores a 1875 revelam a indecisão entre o campo e a cidade. A partir de $A$ Débil, há uma busca da integração urbana, marcada, principalmente pelos poemas Num Bairro Moderno e Cristalizações. A partir de 1880, sua poesia é cognitivamente citadina, como se observa em OSO. Entretanto, a intensidade de tal vivência, segundo Joel Serrão, sem par em nossa poesia, é substituída novamente pelo campo, como bem exemplifica o poema Nós (1884). Não se falava ainda, nessa altura, de ecologia ou meio ambiente, mas Cesário já nos dá conta disso ao apresentar-nos quadros de poluição e degradação ambiental, com funestos resultados, como depreendemos dos versos a seguir: "Foi quando em dois verões seguidamente a Febre/ E o Cólera também andaram

\footnotetext{
${ }^{68}$ MACEDO, op. cit., pp. 184-185.
} 
na cidade, / Que esta população, com um terror de lebre, / Fugiu da capital como da tempestade. (Nós - E.1). Segundo António Capão:

Se os quadros da vida quotidiano da cidade de Lisboa têm para Cesário um valor essencial na sua produção poética, também é verdade que os quadros da vida campestre, ainda que aqui e além se encontrem maculados por um ou outro aspecto negativo, tornam-se como que o grande motivo da descrição e o salutar fim a atingir, espécie de evasão purgativa da vida citadina. ${ }^{69}$

A relação cidade-campo, na obra poética de Cesário, passa por algumas transformações de significado. Inicialmente, o tempo-espaço definido em seus poemas é a cidade, a realidade presente, confinadora e destrutiva, em contraste com o campo, representado pela metáfora antinômica de liberdade. Exemplo é o poema Cantos da Tristeza (1874), que no Livro organizado por Silva Pinto aparece com o título Setentrional. Do ponto de vista pessoal, de um lado a cidade significa ausência, perversão ou impossibilidade amorosa; de outro, o campo significa idílio. Do ponto de vista social, a cidade significa opressão e o campo, possibilidade de libertação. Para escapar dessa dupla limitação, o poeta recorre a uma identificação com o trabalhador rural. O campo, então, despe-se de sua conotação idílica, tornando-se uma realidade concreta, observada em seus múltiplos detalhes e descrita tão minuciosamente quanto a cidade. Nas palavras de Helder Macedo: "[...] um campo de que o trabalho e os trabalhadores são parte integrante, um campo útil onde o poeta se identifica com o povo e de cujas actividades participa." ${ }^{70}$ Tal reformulação expande o contraste cidade-campo para a sociedade agrária-sociedade industrial, esta representada pelas nações do Norte, aquela, pelas nações do Sul, dentre as quais encontramos Portugal. Desta tensão emerge a percepção das injustiças socioespaciais

\footnotetext{
${ }^{69}$ Op, Cit. P. 14.

${ }^{70}$ Op. Cit, p. 46.
} 
e o protesto do autor nelas implícito, o que revela sua visão de mundo desconcertado. O poema Provincianas (1887), incompleto e, ao que se saiba derradeiro, é exemplo disso. Contrapondo a "branca fidalga" às lavradoras, o sujeito poético indaga exclamando: "Não é caso que a comova / Ver as irmãs de leite, / Quer faça frio, quer chova, / Sem uma mamã que as deite / Na tepidez duma alcova?!”. Contudo, longe de reduzir a obra de Cesário Verde e o contexto em que ela se insere a coordenadas estéticas e ideológicas, tal interpretação, segundo Helder Macedo, vem a iluminar o processo de "transformação qualitativa de uma matéria-prima convencionalmente não poética no que é porventura a visão poética mais original da moderna literatura portuguesa." 71

A análise do sujeito poético de OSO, a partir das relações espaciotemporais, demonstra que pari e passu com o percurso pelas ruas de Lisboa está a escrita. Movido pela angústia existencial, decorrente da fragmentação do eu e da nação, seu olhar é atraído pelos elementos espaciais e situações urbanas, do anoitecer ao amanhecer. O ato de escrever para o sujeito poético, em todo o seu percurso angustiante de criação, caótico e indefinido ao início, busca recompor a realidade pela imaginação, desconcertando-a. Segundo Wellek:

Parece possível, contudo, aceitar uma visão que constitui qualquer atividade humana particular como a "iniciadora" de todas as outras, seja ela a teoria de Taine, que explica a criação humana por meio de uma combinação de fatores climáticos, biológicos e sociais, seja a de Hegel e dos helegianos, que consideram o "espírito" a única força motriz da história, seja a dos marxistas, que derivam tudo dos modos de produção. Nenhuma mudança tecnológica radical ocorreu nos muitos séculos entre a Idade Média e a ascensão do capitalismo, ao passo que a vida cultural, e a literatura em particular, sofreram as mais profundas transformações. Tampouco a literatura demonstra sempre, pelo menos imediatamente, consciência das mudanças tecnológicas de uma época: a Revolução Industrial penetrou nos romances ingleses apenas na década de quarenta

\footnotetext{
${ }^{71}$ Idem, ibidem, p.49.
} 
do século XIX [...], muito depois que os seus sintomas fossem claramente visíveis para os economistas e pensadores sociais. ${ }^{72}$

Cesário expressa no poema sua relação de contrariedade com o mundo em que viveu. É ele dessas exceções em que a consciência das mudanças tecnológicas de sua época (Lisboa oitocentista) ocorrem imediatamente em sua lírica. Não se submeteu ao mundo concertado pela técnica que prometia o progresso científico como garantia da felicidade humana no século XIX, conforme atesta o poema analisado. Em vários momentos, ao longo das quatro partes, ou melhor, dos quatro movimentos do poema OSO, o sujeito expressa a angústia provocada pela opressão da sociedade urbana e busca na arte um modo de desconcertar a realidade que oprime e faz sofrer. Se o primeiro movimento se constitui da relação entre realidade exterior e mundo interior, no segundo ela se desconstrói. No terceiro, acontece a transfiguração do sujeito, que volta a si no quarto movimento. As variações citadas permitiram a análise do particular para o geral.

Entretanto cabe notar que o diálogo contínuo entre olho e olhar é uma das linhas de força do poema: se o olho permite a visão do exterior, o olhar compreende a visão interior em sua experiência acumulada. Num primeiro momento, a partir da origem no passado e ordem do presente, o passado histórico e da memória dialogam com o mito e com a realidade do presente no poema. No segundo momento, a análise da relação indivíduonação, através dos monumentos nacionais mencionados, permitiu verificar a expansão do individual ao coletivo, o que me rodeia é o que me preocupa. E no terceiro momento, as relações arte-realidade introduzem uma reflexão sobre a questão da criação literária no (des)concerto do mundo. Citando Carlos Felipe Moisés: "Concerto é o endosso da

\footnotetext{
${ }^{72}$ WELLEK, René; Austin Warren. Teoria da literatura e metodologia dos estudos literários. Trad.: Luís Carlos Borges. São Paulo: Livraria Martins Fontes Editora Ltda., 2003, p. 130.
} 
acumulação reiterada, vezes sem conta; já quando se trata de desconcerto, cada vez é a primeira vez." ${ }^{73}$.

Outro aspecto que nos pareceu importante analisar na obra de Cesário Verde foi a relação campo-cidade, a partir do ambiente criado pelo sujeito poético. Aparecendo ocasionalmente em diversos lugares e épocas, é no século XIX que a ambientação alcança seu florescimento, perdurando até nossos dias. Osman Lins atenta que: "Por ambientação entenderíamos o conjunto de processos conhecidos ou possíveis, destinados a provocar, na narrativa, a noção de um determinado ambiente." ${ }^{74}$ Com os devidos cuidados de transposição para o texto poético de Cesário Verde, podemos depreender que em OSO os passos do sujeito e os versos fluem como que simultaneamente: "Embrenho-me, a cismar, por boqueirões, por becos, / Ou erro pelos cais a que se atracam botes.” (I-5) São, dentre outros, versos que exemplificam essa simultaneidade. Entretanto, lê-se em Leon Sumerlian, que não pode existir pure action in a vacuum (pura ação no vazio) ${ }^{75}$ : "a moderna história realista é ação e cenários." ${ }^{76}$. Descrição e aparente narração alternam-se ou mesclam-se para dissimular o contraste entre motivos dinâmicos e motivos estáticos que o poema oferece. O silêncio e o ruído, a intensidade do vento, o odor e a fumaça, etc., são doações de imagem, de aquisição imediata e satisfatória, que, no poema, expressam a ambientação.

O sujeito, ao referir-se a "gás extravasado", às "chaminés", "fim de tarde", tinir de louça e talheres", "peixe podre”, (Parte I) expressa o ambiente da cidade, em seu cotidiano, durante seu percurso pelas ruas de Lisboa, do anoitecer à madrugada do dia seguinte. $\mathrm{Na}$ Parte II, a ambientação é acentuada, como, por exemplo, "som que mortifica", "esfumo um ermo", "tanger monástico e devoto", "capital, que esfria”. Na Parte III, a ambientação noturna é intensificada por "a noite pesa", "um sopro que arrepia”, "lojas, tépidas",

\footnotetext{
${ }^{73}$ MOISÉS, Carlos Felipe, 2001, op. cit. p. 16.

${ }^{74}$ LINS, Osman. Lima Barreto e o espaço romanesco. São Paulo: Ática, 1976, p. 79.

${ }^{75}$ Tradução nossa.

${ }^{76}$ Apud LINS, op. cit., p.79
} 
"revérberos" e "lunar". O silêncio e a escuridão prenunciam a madrugada na cidade: "teto fundo de oxigênio, de ar", "um parafuso cai nas lajes", "ringem as fechaduras", "sobem no silêncio", "na treva", "nebulosos corredores", "gritos de socorro", “dúbios caminhantes". Falta a visibilidade: "Amareladamente, os cães parecem lobos" e "prédios... com dimensão de montes" expressam a falta de visão de futuro do sujeito lírico na cidade opressiva. Na parte IV delineia-se a esperança no horizonte.

Às vezes, há introdução pura e simples do sujeito para reforçar a franqueza, o perfil cultural do campônio ou do citadino. Ao observar o mundo exterior ele verbaliza o sentimento dele depreendido, introduzindo na ação um hiato. Por exemplo, as imagens "nossas ruas, ao anoitecer", "sombras", "bulício", "maresia” (elementos da observação exterior), ao serem interiorizadas criam um hiato exterior-interior: "Despertam um desejo absurdo de sofrer" que traduz o sentimento por elas deflagrado. O espaço é provocador de sentimento no sujeito; em consequência, ele configura um sujeito como diferente dessa experiência. Altera a realidade pela linguagem; imagens poéticas e seu ser se transformam ao experimentarem sentimentos que lhe eram desconhecidos. Os dois se alteram, portanto: homem e espaço; e os versos são a expressão dessa alteração dupla, mútua ou oposta.

Na relação campo-cidade há uma contrariedade que se manifesta nos versos e vai perdurar ao longo das quatro partes do poema OSO, intensificando-se no decurso da noite até a madrugada, na IV. Nessa hora tardia, seres espectrais vagam sem rumo, sem identidade, provocando diferentes sentimentos no sujeito lírico: "os olhos dum caleche espantam-me", "tristes bebedores”, “dúbios caminhantes", “cães parecem lobos”. A presença desses elementos espaciais, assim como o sujeito que deambula pelas ruas da cidade, denota, por metonímia, a própria crise de identidade da nação portuguesa oitocentista em transformação para acompanhar o progresso técnico de outras capitais européias de seu tempo, representada por Lisboa "massa irregular de prédios sepulcrais, 
com dimensões de montes." (OSO, última estrofe). Outro valor se dá em relação ao campo, que na percepção do sujeito lírico, fornecia produtos que abasteciam banquetes da Europa do Norte: "Oh! Ricos primeurs da nossa terra/ E as tuas frutas ácidas, tardias, / No azedo amonical das queijarias, / Dos flegmáticos farmers de Inglaterra!... // Ó cidades fabris, industriais,/ De nevoeiros, poeiradas de bulha, / Que pensais do país que vos atulha / Com a fruta que sai de seus quintais?" (Nós, 45-46). Um outro valor, que as cidades fabris não têm, estabelece uma forma de equilíbrio na relação Portugal e Europa do Norte. A ironia reverte a ordem da primazia da civilização que se baseia na técnica, no culto ao cientificismo, opondo a ela a ordem da natureza em movimento, expressa na palavra primeurs.

Ao descrever alguns elementos espaciais da cidade ou do campo, o sujeito atribuilhes um texto ficcional, transformando, deste modo, a temática vazia (estática) em uma temática plena (dinâmica). Por exemplo, em OSO: "as edificações somente emadeiradas" (descrição), são dotadas de movimento à comparação de "morcegos" aos mestres carpinteiros que "saltam de viga em viga". Conjugam-se aí fatores de ordem física “edificações” e psicológica (ironia) pelo rebaixamento social dos operários. A partir do texto, podemos encontrar outros casos de ambientação. Tal corresponde a - "Pobres campônios - eram uns heróis", por negociarem com espertos, "entre os mais da sua laia." (Nós, E.83).

Referindo-se à ambientação, Osman Lins coloca: “A ambientação dissimulada (ou oblíqua) exige a personagem ativa: o que a identifica é o enlace entre o espaço e a ação."77. Leon Surmelian designa-a como "método dramático"; e George Lukács sobre ela adverte não se deter na reconstituição do ambiente pela pura descrição e, sim, "quase sempre traduzida em ações" ${ }^{78}$. No poema "O Sentimento dum Ocidental", podemos observar a

\footnotetext{
${ }^{77}$ Idem, ibidem, p. 83.

${ }^{78}$ Idem, ibidem, p. 83.
} 
ambientação oblíqua a partir dos passos do sujeito lírico pelas ruas da cidade. O caminhar faz surgir o espaço que o cerca, como que se ele nascesse desse gesto. Assim, a carga concedida nos versos às emoções do sujeito lírico, dominantes na estrofe, faz parecer casual o elemento espacial, na reconstrução da identidade do "eu"e da nação. Por exemplo: Triste cidade! Eu temo que me avives /Uma paixão defunta! Aos lampiões distantes,/ Enlutam-me, alvejando, as tuas elegantes/Curvadas a sorrir às montras dos ourives. (II-9) Os verbos estão impregnados de energia "avives" (positiva), "enlutam-me" (negativa). O movimento das "elegantes" compensa a imobilidade dos "lampiões", criando o contraste ligado a um momento crucial da vida do sujeito lírico, a crise existencial. A carga concedida à emoção faz passar corriqueiras as ações de "curvar e sorrir às montras dos ourives”. O sujeito caminha e compõe. Como lembra Osman Lins: “[...] a ambientação revela complexidade e engenho na medida em que o narrador [sujeito lírico] recusando a descrição pura e simples tece ordenadamente espaço, personagem e ação. Corresponde melhor um mundo móvel, ou, se imóvel, animado por uma força interior." 79 Tal bem se aplica à poesia de Cesário, de aparente simplicidade coloquial no trato do cotidiano, mas complexa ao desvendar a existência humana. Nesse sentido, o tempo possui um sentido, é um perpétuo andar para frente, um permanente transcender. Nas palavras de Otávio $\mathrm{Paz}^{80}$ : “A temporalidade - que é do próprio homem e que, por conseguinte, dá sentido a tudo em que toca - é anterior à presentificação e é o que a faz possível.” A partir do poema OSO verificamos que o ritmo do caminhar e do escrever ao longo das obras de Cesário Verde atribui sentido novo sentido ao sentido do existir. Depreendemos daí que a simplicidade aparente é efeito da sua construção poética, processo complexo que a partir da fragmentação do sujeito e do mundo busca a totalidade pela dialética compreendida na obra como um todo.

\footnotetext{
${ }^{79}$ Idem, ibidem, p. 85.

${ }^{80}$ PAZ, Otavio. O Arco e a Lira. Tradução de Olga Savary. $2^{\text {a }}$.. Ed. Rio de Janeiro: Editora Nova Fronteira, 1982. p.69. Título original: El Arco y La Lira.
} 


\section{II - ESPAÇO FÍSICO E ESPAÇO DA EMOÇÀO}

“... o espaço é a acumulação desigual de tempos”

(Milton Santos) ${ }^{81}$

Viver no cotidiano a epopeia da existência é um processo que muito se assemelha à realidade que vivemos em nossos dias. A vida humana, na concepção de Martin Heidegger, compõe-se de três aspectos: a facticidade, a existencialidade e a ruína. Viver é um fato natural; existir depende daquilo que se faz com a vida. Ruína é o estágio do que não faz por viver na existência, ser no mundo. O mundo de hoje, globalizado, em sua complexidade dinâmica, de aceleração contínua, transformação do cotidiano determinada pelo valor atribuído ao uso da técnica e pelo sentimento daí decorrente, é, também, consequência da Europa oitocentista. Compreender essa relação pode esclarecer conflitos e, quem sabe, apontar caminhos. O texto que se segue, modesto exercício em direção a isso, pretende ser a busca de um caminho, ou melhor, de um movimento que revele a união inseparável (totalidade) de dois espaços (fragmentação), que se sobrepõem e interagem como corpo e alma: o espaço geográfico e o espaço poético, já mencionados anteriormente no Capítulo I como espaço físico e espaço da emoção. Partindo da reflexão que a essência ou a verdade do mundo transcende à interpretação de dados coligidos por geógrafos, historiadores e sociólogos, Carlos Augusto de Figueiredo Monteiro propõe retirar da Literatura novos aspectos de "interpretação", para enriquecimento da noção de realidade geográfica:

O sustentáculo dessa concepção aparentemente estranha (ou anticientífica), advinda daquilo que se atribui à "revelação literária", é a natureza holística identificável quando a literatura atinge foros de "universalidade", ou seja,

\footnotetext{
${ }^{81}$ SANTOS, Milton. 2007. Op. Cit., Epígrafe de abertura.
} 
quando ela transcende a um caso particular de uma dada região fisicamente vária - para falar da "condição humana" - basicamente una. ${ }^{82}$

Nesse mesmo sentido, Antônio Cândido apresenta dois aspectos básicos do texto literário: acessório e essencial. Citando:

O primeiro é a sua realidade material (aspecto, papel, caligrafia, tipo, estado do texto, etc.), mais a sua história (por quem, como, onde, quando, em que condições foi escrito). É, por assim dizer, o corpo da obra literária e a história deste corpo. O segundo é a sua realidade íntima e finalidade verdadeira: natureza, significado, alcance artístico e humano. É, de certo modo, a sua alma. ${ }^{83}$

Ambos os autores, parece-nos, a princípio, buscam a totalidade. Carlos Augusto pela "natureza holística" da literatura; Antônio Cândido, pela união "realidade externa" e "realidade interna". Para fins de análise do poema, agregamos o sentido da primeira (corpo), espaço geográfico, ao da segunda (alma), o espaço do sentimento.

Em "O mundo desfeito e refeito", Antônio Cândido ressalta que, pelo discurso, o autor reforça ou atenua a semelhança do texto literário com o mundo real. Em suas palavras: "o autor pode manipular a palavra em dois sentidos principais: reforçando ou atenuando a sua semelhança com o mundo real." 84

No poema OSO, a cidade em transformação é acompanhada pelo movimento do sujeito no espaço, o que reforça a semelhança com o mundo real: "E eu sigo, como as linhas de uma pauta/a dupla correnteza augusta das fachadas;", criando sempre novos contrapontos, o que insere um corte transversal no tempo, ao elevar ao plano da emoção a história e a memória, bem como ao projetar, no presente, o futuro mítico. Mais adiante

\footnotetext{
${ }^{82}$ MONTEIRO, Carlos Augusto de Figueiredo. O mapa e a trama: Ensaios sobre o conteúdo geográfico em criações romanescas. Florianópolis: Editora da UFSC, 2002, p.15.

${ }^{83}$ CÂNDIDO, Antônio. Noções de análise histórico-literária. SP: Ass. Editorial Humanitas. 2005, p. 13.

${ }^{84}$ CÂNDIDO, Antônio e J. A. Castello. Presença da Literatura Brasileira. Modernismo. Rio de Janeiro: Bertrand, 1992.p.30.
} 
veremos exemplos disso. No que tange à escrita e à criação, também se percebe o movimento: "E eu, de luneta de uma lente só,/ Eu acho sempre assunto a quadros revoltados", que busca na composição dos versos uma saída da situação de angústia em que se encontra, provocando no leitor um deslocamento espaciotemporal que pode fazê-lo refletir criticamente sobre o espaço em que vive.

Acerca da mobilidade no espaço, Antônio Cândido lembra que "Goethe acertou ao incluir a mobilidade no espaço entre as prendas dignas de serem oferecidas por Mefistófeles à ambição de Fausto" ${ }^{85}$. E justifica dizendo que foi graças a ela que a civilização burguesa pode se expandir e firmar. Se, em "Fausto", a mobilidade é representada por seis cavalos, no alvorecer da modernidade no século XIX, ela é representada pelo uso do vapor, da máquina, do telégrafo, entre outros meios técnicos para “palmilhar o mundo e esquadrinhá-lo, na procura verdadeiramente fáustica do enriquecimento pessoal" (idem), hoje intensificado pela globalização, aqui entendida do ponto de vista hegemônico da economia. Diferente disso, no poema em causa, é o percurso a pé pelas ruas de Lisboa, em OSO, que conota a valorização da dimensão humana no espaço geográfico.

Ao tratar o espaço como uma totalidade em movimento, o sujeito poético nos permite uma abordagem geográfica do espaço no poema, como território vivido, ou seja, território praticado. Por este prisma, o espaço do sentimento no texto talvez possa ser compreendido à luz dos conceitos da geografia, tais: território usado, paisagem, rugosidade e lugar. Como fundamento a essa compreensão, a leitura da obra do geógrafo brasileiro Milton Santos, "A Natureza do Espaço: técnica e tempo, razão e emoção", é bem elucidativa:

Os movimentos da sociedade, atribuindo novas funções às formas

\footnotetext{
${ }^{85}$ CÂNDIDO, Antônio. Entre Campo e Cidade. In: Tese e Antítese. São Paulo. Companhia Editora Nacional, 1964. p.38.
} 
geográficas, transformam a organização do espaço, criam novas situações de equilíbrio e ao mesmo tempo novos pontos de partida para um novo movimento. Por adquirirem uma vida, sempre renovada pelo movimento social, as formas - tornadas assim formas-conteúdo - podem participar de uma dialética com a própria sociedade e assim fazer parte da própria evolução do espaço. ${ }^{86}$

Tendo em vista a verossimilhança entre espaço poético e espaço geográfico, buscamos uma aproximação de ambos, para melhor interpretarmos, de um lado, o mundo em que o poeta viveu; e, de outro, o mundo representado no poema, para verificar a relação entre eles, e daí depreendermos a visão de mundo do autor. Ocorreu-nos tal procedimento não só pelos próprios cânones do Realismo e Naturalismo, que se propõem a ser fiéis à descrição da realidade consoante ao espírito de observação resgatado do cartesianismo, portanto, racional; mas, sobretudo, pela peculiaridade da poesia cesariana que conota frustração e busca de alternativa quando em tal impossibilidade. Por exemplo: "Longas descidas! Não poder pintar / Com versos magistrais, salubres e sinceros, / A esguia difusão dos vossos revérberos, / E a vossa palidez romântica e lunar!” (OSO, III-6). Na estrofe transcrita, se os pontos de exclamação expressam o sentimento de frustração do sujeito ante tal impossibilidade, outros recursos verbais remetem ao impressionismo pictórico, pelas imagens fugidias, sem contorno definido, que as palavras "difusão", "revérbero", "palidez" e "lunar" evocam, propondo outra saída, que transponha o interdito representado pelo advérbio "não", seguido dos infinitivos "poder pintar", o que revela a complexidade da poesia de Cesário ao se propor expressar a realidade cotidiana. Tal remete a Hauser ${ }^{87}$, quando diz: "De qualquer modo é mais conveniente chamar de naturalismo a todo movimento artístico em discussão aqui e reservar o conceito de realismo para a filosofia oposta ao romantismo e seu idealismo".E, em seguida, sintetiza: "O realismo seria a atitude

\footnotetext{
${ }^{86}$ SANTOS, Milton. 1999, Op, Cit., p.86.

${ }^{87}$ HOUSER, História Social da Arte e da Literatura. Tradução de Álvaro Cabral. São Paulo: Livraria Martins Fontes Editora Ltda. 2003 (Paidéia), p. 791.
} 
filosófica, o naturalismo, o estilo artístico.” Em outras palavras, a aplicação das ciências exatas à descrição artística dos fatos. Daí a riqueza de detalhes e a importância atribuída ao circunstancial, por mais trivial que seja. Refletindo sobre isso, podemos dizer que mais do que um estilo, a poesia de Cesário reflete uma causa real. E que realidade seria essa? Para responder a essa pergunta, valemo-nos dos conceitos de território usado, paisagem, rugosidade e lugar encontrados na obra de Milton Santos, na medida em que a análise do texto assim o demandou, conforme exporemos a seguir, com as devidas ressalvas.

Considerando realidade aquilo que a linguagem é capaz de expressar, nossos estudos pretenderam buscar fundamento em alguns conceitos referentes ao espaço geográfico para melhor compreender a questão da verossimilhança na poesia de Cesário Verde. Embora o poeta localize em Lisboa o espaço em seu poema, a cidade adquire conotação universal pelo tratamento lírico a ela destinado desde o título, O Sentimento dum Ocidental, ou seja, a manifestação subjetiva de um indivíduo qualquer do Ocidente. Neste espaço, que, no presente do sujeito poético é a cidade de Lisboa e a expressão exclamativa “Triste cidade!” bem revela seu sentimento, lê-se um conjunto de objetos e de ações, que, no tempo, remontam à memória, ao passado histórico e ao futuro, a partir do mito. Por exemplo: "Num cardume negro assomam as varinas" (presente); "Luta Camões ao sul, salvando um livro a nado" (história/memória); "A raça ruiva do porvir" (futuro mítico). No primeiro verso o movimento das peixeiras ambulantes pelas ruas que o sujeito observador percorre; no segundo verso, a recuperação do passado pela memória; e, no terceiro verso, a projeção do herói do passado na construção do futuro (filho dos navegantes portugueses e das ninfas de Tétis, que remete à narrativa épica). Daí depreendemos, a partir do texto, que Cesário trabalha no referido poema a complexidade dinâmica do território usado, "um conjunto indissociável de sistema de ações e sistema de objetos." ${ }^{88}$. O sujeito, imerso na

\footnotetext{
${ }^{88}$ Idem, ibidem: p. 267.
} 
cidade, depreende dela as relações espaciotemporais que vai sobrepondo enquanto caminha pelas ruas. Se as descrições generosas de formas e das relações sociais dão o tom naturalista e realista ao poema, as imagens de cor e movimento tecem as nuanças impressionistas que se fazem presentes pelo efeito da luz, no detalhe do cotidiano, acurando as percepções sensoriais do tempo, entre outros elementos compositivos, que abordaremos no Capítulo III, ao tratarmos de traços da pintura impressionista na poesia de Cesário. Ainda refletindo o território usado, também o campo se apresenta na obra poética como "um conjunto indissociável de sistema de ações e sistema de objetos", que se opõe à cidade, conforme vimos expondo ao longo da dissertação. Nesse sentido, a presença da natureza, por vezes, é marcada pela exiguidade de sua existência ou mesmo ausência na cidade. Por exemplo, as expressões "exíguas pimenteiras" e "sem árvores", em OSO, conotam a preocupação do autor com sua extinção no meio urbano.

A paisagem é um elemento do espaço, é a materialidade visível, até onde a vista alcança: "conjunto de formas, que num dado momento, exprime as heranças que representam as sucessivas relações localizadas entre homem e natureza." ${ }^{89}$. No caso de OSO, em vários momentos o olhar panorâmico do sujeito divisa a paisagem a distância e, em relação ao foco, ao que é próximo, ressaltando a importância do espaço na lírica. São exemplos disso: "Em uma catedral de um comprimento imenso", vista à perspectiva da rua iluminada, a céu aberto; e o "ventre das tabernas", visto de perto, pelo passante.

O movimento entre o olhar panorâmico, que capta a dimensão do geral, e o olhar de foco, que examina o detalhe, faz valer para o leitor o contraste entre ambas as situações criadas pelo sujeito. A ausência de limite entre o fora e o dentro, em algumas situações por que passa o sujeito, revelam, de certo modo, a visão de mundo do autor, que é de insatisfação com a ordem estabelecida. Ao dispor dos contrários em sua lírica, o autor

\footnotetext{
${ }^{89}$ Idem, ibidem: p.83.
} 
prenuncia o Modernismo. Explicando melhor: se o efeito da iluminação, de um lado, transmuta a rua (espaço aberto) em catedral (espaço fechado); de outro lado, ele expõe o espaço fechado "ventre" como espaço aberto "tabernas", invertendo a ordem espacial tradicional do dentro e fora absolutos. Ao romper os limites dentro-fora, instaura-se a relatividade, moderna.

No campo, a paisagem natural se mescla à transformada pela mão do homem ou pelo meio técnico, como nos versos que se seguem: "Na ribeira abundam as ramagens / Dos olivais escuros. Onde irás? / Regressam os rebanhos das pastagens; / Ondeiam milhos, nuvens e miragens, / E, silencioso, eu fico para trás.” (De Verão, E.5). Entre o olhar a paisagem e o conversar com a prima, imagens cotidianas do campo se sucedem na visão do sujeito. Com predomínio dos substantivos, "ribeira", "ramagens", “olivais", "rebanhos", "nuvens" e "miragens" o espaço se constitui por justaposição de cenas. A idéia de movimento advém dos verbos no presente, "regressam", “ondeiam", em oposição a “abundam" e "fico", que denotam estaticidade. As expressões "na ribeira" e "para trás", reforçadas pelo advérbio "onde", posicionam o sujeito em relação à paisagem e à companheira de passeio. Os adjetivos "escuros" e "silencioso" conotam um ambiente de calma e frescor compatível com a natureza. Em Nós, a paisagem do campo vem por vezes carregada de contrariedades relacionadas à lavoura e à comercialização de produtos agrícolas; "É o pulgão, a lagarta, os caracóis, / E há inda, além do mais com que se ateima, / As intempéries, o granizo, a queima, e a concorrência com os espanhóis". (E. 95), que lhe atribuem valor negativo. O positivo e o negativo depreendidos da paisagem urbana e rural se alternam na obra poética de Cesário, denotando que o campo e a cidade, longe de serem paraísos idealizados, são lugares de trabalho e desafios que o homem pela técnica procura vencer, para deles extrair o próprio sustento e, somado a ele, quiçá, o lucro, em uma sociedade capitalista. 
Ao longo do percurso do sujeito pelas ruas de Lisboa do século XIX, ele observa algumas cristalizações espaciotemporais. Restos do passado e cicatrizes da decadência são exibidos no cotidiano, ao longo desse percurso, o que remete ao conceito de ruína, de Heidegger, estágio de que não faz por ser na existência. Ao que fica do passado como forma, paisagem, Milton Santos chama de rugosidade. Vistas individualmente ou em seus padrões, as rugosidades revelam combinações possíveis de um dado tempo e lugar. Neste sentido, alguns versos do poema em questão podem conotar rugosidade. A título de exemplo: "Na parte que abateu o terremoto". O vazio e os destroços resultantes do cataclismo que abateu Lisboa em meados do século XVIII permanecem na paisagem, revelando o que ali existiu e já não mais tem a mesma função. Tal reflexão talvez possa se aplicar, de certo modo, à natureza e, ao contrário do romance realista e naturalista de Eça de Queirós, “A Cidade e as Serras”, em que a oposição cidade/campo conduz à salvação do homem pelo convívio com a natureza; em OSO, quando ela raramente aparece, lembra uma rugosidade, ou seja, sua existência em dado tempo e lugar. A expressão "exíguas pimenteiras" é exemplo do remanescente empobrecido da natureza na paisagem da cidade e de sua desvalorização ante a construção civil, bem como remete ao comércio de especiarias do século XVI, que enriqueceu Portugal no passado histórico.

No campo, a partir da análise do texto, a rugosidade pode ser sinônima de estagnação e morte, como se lê nos versos que se seguem: “Como em paul em que nem cresça a junca / Sei de almas estagnadas! Nós absortos, / Temos ainda o culto pelos mortos, / esses ausentes que não voltam nunca mais!" (Nós, E.120) Ao sobrepor as imagens de paul estéril e almas estagnadas, o sujeito lírico sobrepõe ao espaço físico, representado pelo substantivo concreto paul, o espaço do sentimento, representado pela expressão "almas estagnadas!”.A tradição do culto pelos mortos, com a conotação religiosa, perde sua função original, tornando-se uma rugosidade, pois "mortos", no caso, é metáfora de seres ausentes. 
Na obra poética de Cesário Verde, há criação de vários lugares. Entendemos por lugar o espaço do acontecer solidário. Citando Milton Santos: "Lugar é o espaço do acontecer solidário. A noção, aqui, de solidariedade, é aquela encontrada em Durkheim e não tem conotação moral, chamando a atenção para a realização compulsória de tarefas comuns, mesmo que o projeto não seja comum." ${ }^{, 90}$. É no lugar que acontece o cotidiano. Em "O Sentimento dum Ocidental", o cotidiano se dá nas ruas, largos, quadras, bairros e outros elementos espaciais que compõem a cidade. Por exemplo: "O gás extravasado enjoame, perturba," (I-2) e "Voltam os calafates, aos magotes,/ De jaquetão ao ombro, enfarruscados, secos;" (I-5). Durante seu percurso aleatório pelas ruas de Lisboa, ao perceber os variados lugares, sendo que "cada lugar é, à sua maneira, o mundo", ou, como afirma Maria Adélia Aparecida de Souza "todos os lugares são virtualmente mundiais" 91, o sujeito poético revela o momento de sua emergência e pressupõe sua intersubjetividade. Do texto: "Como morcegos, ao cair das badaladas,/ Saltam de viga em viga os mestres carpinteiros.”(I-4e5) ou “E de uma padaria exala-se, inda quente, / Um cheiro salutar e honesto a pão no forno.” (III-4), como exemplos de lugares de trabalho que não passaram despercebidos ao sujeito: de um lado, a animalização do homem pelo excesso do trabalho "morcegos ao cair das badaladas", e, de outro, a valorização do trabalho humano "cheiro salutar e honesto a pão no forno". Por sua vez, o campo como lugar de trabalho está presente em outros poemas: De Verão e Nós, de que os versos seguintes são respectivos excertos: "Quanto me alegra a calma das debulhas!” (E.3); “Tu cortavas os bagos que não prestam / Com a tua tesoura de bordar!” (E.35).

Como lugar de lazer, na cidade, predomina o do estrangeiro e o do alienado, de que “emigrados" e "tristes bebedores" são representantes nos versos a seguir: "Entro na brasserie; às mesas de emigrados / Joga-se, alegremente e ao gás, o dominó!” (II-11). E, na

\footnotetext{
${ }^{90}$ Idem, ibidem: p. 132.

${ }^{91}$ In: idem, ibidem, p. 252.
} 
referência à boêmia: “... aos bordos sobre as pernas, / Cantam de braço dado, uns tristes bebedores." (IV-8). No campo, o lugar de lazer configura-se pela presença de elementos estranhos a ele. Por exemplo, a da prima citadina, observadora da natureza em "lírica excursão", no poema De Verão; e pela presença da companheira, hóspede que se assusta com as bezerrinhas e vaca, num "giro pelo vale".

No campo, o lugar é o espaço do abrigo àqueles que fogem das epidemias da cidade e de solidariedade: "Foi quando em dois verões seguidamente a febre/e o Cólera também andaram na cidade." (Nós, E.1). É, também, o lugar de solidariedade que se opõe à solidão da cidade: "Ele, dum lado, viu os filhos achacados, / Um lívido flagelo e uma moléstia horrenda! / E via, do outro lado, eiras, lezírias, prados,/ E um salutar refúgio e um lucro na vivenda!"(Nós, E. 11) O verbo ver no pretérito perfeito (viu) indica uma ação acabada, denotando as desgraças vividas no ambiente urbano, lugar de flagelo e moléstia; e o mesmo verbo, no pretérito imperfeito (via), denota a continuidade de ação benéfica do meio rural, lugar de refúgio e lucro, projetado no presente do sujeito poético. Se aquele tem a conotação negativa, como os adjetivos achacados, lívido e horrendo expressam; este conota a esperança de vida profícua que o adjetivo salutar reforça. Ao longo da obra poética de Cesário Verde pode se constatar lugares que se opõem, formando pares dialéticos, que dão a visão da harmonização das diferenças de seus componentes. Por exemplo: morte e vida; mulher angelical e mulher satânica, operário e patrão, calceteiro e lavrador, camponesa e aristocrata, entre outros que estão disseminados na obra e podem ser recolhidos no poema O Sentimento dum Ocidental ou vice-versa, indicando, de um lado a fragmentação do espaço e, de outro, a busca da totalidade pela harmonização da composição poética. Vale ressaltar o uso da ironia, forma dada às antinomias e contradições específicas do lavrador e comerciante burguês, ambas as atividades presentes na vida do poeta, evidenciando o antagonismo essencial entre propriedade e trabalho, que sua lírica busca conciliar. 


\section{COTIDIANO E PERCURSO}

Este segundo capítulo, articulado ao anterior, busca desenvolver a questão do cotidiano e do percurso do sujeito no poema OSO, de Cesário Verde. A abordagem do cotidiano, entendido como: "aquilo que nos é dado cada dia (ou que nos cabe em partilha), nos pressiona dia após dia, nos oprime, pois existe uma opressão do presente." ${ }^{.92}$. O dia a dia de um indivíduo, na metrópole portuguesa do século XIX, mostra através das relações espaciotemporais: a situação interna de Lisboa, uma cidade em transformação pelo uso da técnica industrial, em seus aspectos positivos e negativos; e a situação de Lisboa no cenário europeu da época. Evocadas pelo sujeito poético, que expressa seu sentimento de ocidental, a história e memória são presentificadas pelo caminhar e escrever, ao mesmo tempo em que um outro futuro é almejado. A dificuldade de viver nesta condição denota ora a fadiga, ora o desejo de uma outra condição. Visto por este prisma, "o cotidiano é aquilo que nos prende intimamente, a partir do interior. É uma história a meio-caminho de nós mesmos, quase em retirada, às vezes velada." 93

No que diz respeito ao percurso, compreendemos que ele introduz a organização territorial e o dinamismo dos lugares no texto, pelo caminhar. Compreendemos, também, que no conceito de Michel de Certeau cada passo é entendido como algo qualitativo, de apreensão táctil, de apropriação cinética: Os jogos dos passos moldam espaços. Tecem lugares. Os passos do sujeito traçam um percurso aleatório pelas ruas de Lisboa, transcrevendo a cidade em traços (aqui mais densos, ali mais leves) e prescrevendo trajetórias (passando por aqui e não por lá), que revelam a escolha do que é observado e o

\footnotetext{
${ }^{92}$ CERTEAU, Michel de; Luce Giard; Piere Mayol. A Invenção do cotidiano: 2. Trad. de Ephraim F. Alves e Lucia E. Orth. 6a. ed. Petrópolis RJ: Vozes, 2005, p.31.

${ }^{93}$ Idem, ibidem, p. 31.
} 
sentimento decorrente. O próprio ato de ir, vagar, olhar manifesta um modo de estar no mundo, representado pelas imagens concebidas.

Diferentemente da tradição lírico-sentimental, em que o sujeito que fala nos poemas se apresenta como entidade mística, situada num plano em elevação (púlpito, palanque ou palco), acima dos pobres mortais, a voz presente na poesia de Cesário Verde expressa o "eu" que desceu ao nível pedestre e fala com a voz comum do dia a dia. Ao tomarmos por base o conceito de cotidiano: “Todo dia, pela manhã, aquilo que assumimos, ao despertar, é o peso da vida, a dificuldade de viver, ou de viver nesta ou noutra condição, com esta fadiga, com este desejo." 94 Seus versos impregnados da realidade contingente apreendida e fixada pelo olhar penetrante do poeta que se imiscui entre as coisas e situações cotidianas, as quais, por serem comuns, passam despercebidas aos menos atentos, causaram estranhamento em muitos de seus contemporâneos que preconceituosamente acusaram sua lírica de antipoética e de "mau-gosto". Entretanto, como se lê no fragmento seguinte:

Cesário não tenta exorcizar fantasmas, não foge do Romantismo, com ataques furiosos, apaixonadamente românticos, mas enfrenta-o com naturalidade, adota-lhe is temas e motivos mais convencionais, para raspar com certeira ironia a camada de agitação e teatralidade que os recobre. Pare ele, o debate não se trava entre uma "escola" romântica e uma "escola" realista, mas entre um sujeito real, pés na terra (e espírito um pouco nas nuvens, sem dúvida, caso contrário...), e as coisas em redor: formas, cores e cheiros do ambiente urbano ou rural; pessoas e objetos palpáveis; idéias; sentimentos e aspirações enraizadas nas reais circunstâncias de vida. ${ }^{95}$

Essa naturalidade se expressa pelo coloquialismo e pela oralidade do sujeito poético, dando tom natural à composição que começa como uma conversa espontânea:

\footnotetext{
${ }^{94}$ Idem, ibidem, p.31.

${ }^{95}$ MOISÉS, Carlos Felipe. 2001, op.cit. , p. 209.
} 
"Nas nossas ruas, ao anoitecer", incluindo na primeira pessoa do plural seus interlocutores e nós, leitores, a um só tempo. Se o tom coloquial presentifica o cotidiano, a oralidade instaura o aqui e o agora no presente constante da lírica. atribuindo-lhe espontaneidade popular: "Que as sombras, o bulício, o Tejo, a maresia", elementos comuns do anoitecer em Lisboa, "Despertam um desejo absurdo de sofrer.” (I-1)

O cotidiano pulsante em sua obra faz de Cesário "um poeta do seu tempo, como raros outros o conseguiram ser, um tempo de burguesia e capitalismo em crise, um tempo em que a própria Arte, em crise, sai do ateliê e "baixa" às ruas. Um tempo, em suma, que em muito se assemelha ao atual, herdeiros que somos das mesmas crises." ${ }^{\text {" }}$. Rompendo com a tradição do exótico e do grandioso, é nos elementos urbanos e nas situações vivenciadas no cotidiano que o poeta busca sua inspiração. Na sequência aos versos iniciais, ainda na Parte I do poema, é à vista dos elementos espaciais do presente: gás, turba, carros de aluguer, via férrea, edificações, cais, que o sujeito lírico, por um instante, evoca o passado dos heróis, contido nas crônicas navais, a epopéia portuguesa "Os Lusíadas", buscando a tudo ressuscitar: "E evoco, então, as crônicas navais;/Mouros, baixéis, heróis, tudo ressuscitado!/ Luta Camões no Sul, salvando um livro a nado!/ Singram soberbas naus que eu não verei jamais!" Logo em seguida, a realidade do presente o atrai de volta ao cotidiano que ele passa a descrever nas três estrofes seguintes, de forma fragmentada: "E o fim de tarde inspira-me e incomoda! / De um couraçado inglês vogam os escaleres; E em terra num tinir de louças e talheres / Flamejam, ao jantar, alguns hotéis da moda.", conotando a forte presença estrangeira na "frágil" capital lisboeta.

$\mathrm{E}$, entre as atividades que encerram o dia de trabalho, opondo-se a imagem da predominância estrangeira na cidade, aparecem as varinas, vendedoras ambulantes, que, ao longo do cais da Ribeira, estridentemente comercializam o pescado. Representam, no

\footnotetext{
96 “Cesário Verde. Poesia completa e cartas escolhidas. Edição organizada, prefaciada e anotada por Carlos Felipe Moisés. SP: Cultrix, 1982, p.7.
} 
contexto da cidade, a tradição portuguesa no presente, no dia a dia, mesmo em condições miseráveis de vida, conforme a sucessão de imagens da pequena narrativa inserida nos versos que encerram a Parte I. São elas as obreiras do presente: "Seus troncos varonis recordam-me pilastras", trabalhadoras tenazes de pé no chão, da terra, que "à cabeça, embalam nas canastras / Os filhos que depois naufragam nas tormentas.", como naufragaram os antigos navegadores lusitanos. A expressão "à cabeça", de suma importância para a interpretação da décima estrofe, conota dois sentidos, o físico, sobre a qual carregam as canastras com os filhos pequenos, e o do sonho que lhes embala o futuro, sem saída. "Descalças! Nas descargas de carvão, / Desde manhã à noite, a bordo das fragatas;/ E apinham-se num bairro aonde miam gatas, / E o peixe podre gera focos de infecção!”, estrofe final da Parte I que expressa com força naturalista o cotidiano subhumano de suas vidas miseráveis.

Oscilando entre a opressão citadina do cotidiano e a busca de um respiro na existência, os versos decassílabos e alexandrinos expressam a busca da totalidade da vida ante a fragmentação do dia a dia. Esta toante é permanente até o final: "E, enorme, nesta massa irregular / De prédios sepulcrais, com dimensões de montes, / A Dor humana busca os amplos horizontes, / E tem marés de fel, como um sinistro mar!” (IV-11). Ao emocionar-se ante o real cotidiano, o poeta, dividido entre o que vê e o que sente, busca na composição dos versos uma conciliação com a existência. Nas palavras de Massaud Moisés, que bem nos esclarecem, entendemos melhor esse conflito: "E sua emoção revela existir no seu espírito uma ambivalência, quer dizer, a paisagem citadina o seduz como um visgo, e ao mesmo tempo o repele, tornando-o um estranho a vagar sem rumo "no vale escuro das muralhas!" 97

\footnotetext{
${ }^{97}$ MOISÉS, Massaud. 1971. Op. Cit., p. 313.
} 
O caminhar aleatório do sujeito pelas ruas de Lisboa, ao mesmo tempo em que compõe os versos de OSO, pode ser considerado como os dois lados de uma mesma moeda. Em sua superfície presente projeta-se o passado opaco e o futuro incerto, havendo uma sobreposição temporal. O sujeito poético, em sua deambulação do anoitecer ao amanhecer do dia seguinte, vai tecendo traços e trajetórias (passando aqui e não por lá) como uma maneira de estar no mundo. A partir da rua, em movimento contínuo, o sujeito observa a realidade que o comove. Citando:

De qualquer forma, o dia-a-dia da cidade de Lisboa adentra pela primeira vez o privilegiado território poético: ruas, praças e becos; a Baixa pombalina, o Bairro Alto; os bairros modernos, de traçado amplo e arejados, e a zona portuária, sombria e malcheirosa; os mais variados tipos humanos, com predomínio dos humilhados e ofendidos, e assim por diante. ${ }^{98}$

Lisboa oitocentista, uma cidade de pequenos burgueses, operários, comerciantes, indivíduos em atividades ainda dependentes da vida rural, situações coletivas de trabalho e angústia existencial por ignorarem seu destino ao ingressar na era industrial, adentra o território poético. E, neste caso, a geografia possibilita, através da verossimilhança, enxergar, de um lado, a realidade de que partiu o poeta, ou seja, o "território usado", segundo Milton Santos; e, de outro, remete à reconstrução do sujeito e da nação, no poema. Por exemplo, em OSO, Cesário não cita nome de ruas, de bairros, logradouros ou casas de comércio que nos deem referência toponímica. Não obstante, elementos espaciais no poema permitem uma ideia do percurso do sujeito lírico pela cidade, que buscamos a seguir, em largos traços, descrever.

\footnotetext{
${ }^{98}$ MOISÉS, Carlos Felipe. 1982, op. Cit., p.5.
} 
Iniciando sua caminhada pelo bairro Chiado, de onde a via férrea leva "os que se vão, felizes!" (I-3), ele desce à Ribeira "cais a que se atracam botes" (I-5); e, passando pelos edifícios do antigo Aljube, “das prisões, da velha Sé, das Cruzes” (II-2) e pela "parte que abateu o terremoto" (II-5), sobe novamente pelo Chiado até o Largo de Camões, "recinto público e vulgar”, "um épico doutrora ascende, num pilar!”. Pelo Bairro Alto segue em direção à Baixa por "Longas descidas" (III-6), iluminadas a gás; o bairro comercial elegante da cidade onde "desdobram-se tecidos estrangeiros" e "flocos de pó de arroz pairam sufocadores" é revisto, antes de se apagarem "nas frentes / Os candelabros" e de tornarem-se "mausoléus as armações fulgentes." (III-10), que indicam a noite fechada. Daí, pelas vielas medievais atrás do Castelo "ao meio das trapeiras", "às escuras" (IV-1/2), sem iluminação artificial, o sujeito lírico prossegue “[...] como as linhas duma pauta” pelos "nebulosos corredores", até que da Alfama, de madrugada, tem a visão da cidade "De prédios sepulcrais, com dimensões de montes”. A oposição cidade medieval (originária) e cidade pombalina (moderna) se faz pela dialética noite natural e noite técnica, cabendo aqui notar que é do ponto original (Alfama) que o olhar do sujeito lírico busca o amanhecer no mar, conotando a visão de futuro. O mar, que representa o perigo do desconhecido e a busca de superação, aqui remete à ideia do movimento, ritmo natural da maré, com sentido negativo, de fel, amargura, no sentido oposto de origem da vida. Remete, também, às antigas naus dos descobrimentos, símbolo da aventura grandiosa do povo português, que antes o percorriam e são, no poema, substituídas por botes e barcos estrangeiros "couraçado inglês"(I-7). Embora escassa, a imagem do mar pode ser observada em outros poemas de Cesário, com sentido positivo, de vida e alegria, associada à natureza campestre: "E o mar um prado verde e florescente.” (De Verão, E.15); ou conotando a experiência da fusão amorosa no campo, acentuada pela palavra "ondas": "Eu contigo, abraçados como heras, / Escondidos nas ondas dos trigais"; ou, ainda, como imagens espaciais de ausência de 
limites para o sentimento amoroso: "unidos ambos / Num amor grande como o mar sem praias." (Setentrional E. 8-9). Segundo Helder Macedo, ao retomar a "iconografia romântica do mar”, na expressão de W.H.Auden, mar e cidade são símbolos opostos:

O mar, como símbolo de uma desconfinada amplidão, e o campo são, portanto, metáforas sinônimas: a cidade limitadora é contrastada não com o campo real, mas com o amor sem limites que o campo, como uma metáfora da ausência de todos os limites (pura paisagem esvaziada não só de outras presenças humanas mas também de quaisquer construções que a pudessem aproximar da cidade), serve para significar. ${ }^{99}$

No poema Meridional, o símbolo da sensualidade feminina, "longos cabelos", é associado ao mar: "Ó vagas de cabelo esparsas longamente, / Que sois o vasto espelho onde me vou mirar," (Cabelos - E.1) Esta complexa imagem, onde o mar é ao mesmo tempo espelho, remete a Narciso, ou seja, ser no outro, o que implica um desdobramento por distorção do sujeito.

É comum, na obra, o autor se valer de expressões aquáticas, como é o caso no poema Capricho, do qual foram extraídas as expressões que se seguem: "vestidos afogados", "praias rumorosas", "sussurro do mar", "náufragos aflitos", "mergulha-se em angústias", que remetem à imagem abstrata de imensidão do mar; assim como são frequentes as imagens mais voltadas para a realidade concreta, como é o caso do verso " $\mathrm{Na}$ muralha dos cais de cantaria" (Noitada, E. 22), em que os substantivos concretos "muralha", "cais" e "cantaria" expressam a ideia de fortaleza relacionada à pedra, a qual, no caso, tem valor negativo, pois demarca a frustração amorosa prenunciada no verso inicial da estrofe: "E ali começaria o meu desterro!..." (idem).

\footnotetext{
${ }^{99}$ MACEDO. Op. cit.p. 52.
} 


\section{ANTINOMIAS DIALÉTICAS}

Se o caminhar do sujeito poético pelas ruas da cidade denota a horizontalidade do percurso, os elementos espaciais descritos por ele conferem, ao longo da obra, significativas oposições de verticalidade, como é o caso da expressão "céu baixo", no início da segunda estrofe do poema OSO, em que o adjetivo "baixo" inverte o valor tradicional de altitude ou infinitude do céu, atribuindo-lhe nova conotação, ou seja, a de opressão "O céu parece baixo e de neblina." Acerca dos eixos alto/baixo, Lotman elucida:

Os modelos do mundo sociais, religiosos, políticos, morais, os mais variados, com a ajuda dos quais o homem, nas diferentes etapas da sua história espiritual, confere sentido à vida que o rodeia, encontram-se invariavelmente providos de características espaciais, que sob a forma da oposição "céu - terra" ou "terra" reino subterrâneo" (estrutura vertical de três termos, ordenada segundo o eixo alto - baixo), quer sob a forma de uma certa hierarquia político-social com uma oposição marcada dos "altos "aos "baixos", noutro momento. ${ }^{100}$

As longas subidas, por exemplo, representam, neste contexto, as dificuldades que demandam um sobre-esforço de elevação no caminhar. O subir até o alto busca uma visão em perspectiva da cidade abaixo, livre, portanto, da opressão. O sujeito lírico, nesta situação, coloca-se como voyeur, a distância, e passa a ter o mundo, que o enfeitiçava, diante de si. Estabelece-se, a partir daí, uma outra relação com o mundo, que permite lê-lo em vez de ser possuído por ele. Entretanto, essa leitura, diferentemente da que Baudelaire faz da metrópole francesa em “As Flores do Mal”, de predominante temática satânica, é de oposição crítica a Lisboa, em seu estado caótico, e solidária à dor de seus habitantes, a

\footnotetext{
${ }^{100}$ LOTMAN, Iuri. A estrutura do texto artístico. Trad.: Maria do Carmo V. Raposo e Alberto Raposo. Lisboa: Editorial Estampa, 1978, p.360.
} 
partir de Num Bairro Moderno (1877); e quando Cesário alcança sua própria originalidade e coloquialismo, ao colocar diante de nossos olhos e ouvidos a realidade injusta da morte de um operário caído de um andaime em Desastre (1875). Outro exemplo encontramos na Parte II do poema OSO, quando, após vencer as "íngremes subidas", do alto de um "recinto público e vulgar", à vista dos "lampiões distantes", o sujeito poético expressa sua revolta ante a cidade do presente e a da memória, representada pelas imagens naturalistas, que evocam de um lado as epidemias de cólera e febre amarela do passado: "Nesta acumulação de corpos enfezados" (II-7), a cidade do passado histórico, da memória; e, de outro, ante as imagens de sobrecarga de trabalho, o que deixa exaustas as floristas/coristas, a cidade do presente: "custa-lhes a elevar os seus pescoços altos" (II-10). Ambas as cidades, do presente e do passado, justapostas no tempo, como descrevem os versos "Dos arcos dos quartéis que já foram conventos; / Idade Média! A pé, outras, a passos lentos, / Derramamse por toda a capital, que esfria." (III-8), provocam sua revolta contida: "E eu, de luneta de uma lente só, / Eu acho sempre assunto a quadros revoltados:” (II-11). Em seguida, o sujeito poético anuncia sua atitude imediata: "entro na brasserie", e a proximidade dos emigrados que às mesas jogam "alegremente e ao gás, o dominó" provoca nele nova atitude, cujas palavras iniciam a Parte III do poema: "E saio. A noite pesa, esmaga". Cabe aqui notar que o enjambement do primeiro verso: "Nos / Passeios de lajedo arrastam-se as impuras." (III-1) dá forma ao sentido de continuar o caminhar do sujeito lírico, ao mesmo tempo em que, dialeticamente, os canos dão a ideia de obstáculo em: “As burguesinhas do catolicismo / Resvalam pelo chão minado pelos canos.” (III-3).

Em oposição à expressão “íngremes subidas” (II-5), formando com ela o par dialético "Longas descidas" (III-6), do alto, enfim, o sujeito lírico eleva-se ao desejo poético que a visão da cidade inspira e, simultaneamente, reconhece o interdito: "Não poder pintar / Com versos magistrais, salubres e sinceros. / A esguia difusão dos vossos 
revérberos. /E a vossa palidez romântica e lunar!", que o faz cair na realidade. Ironicamente, a lua, longe de conotar o idílio amoroso romântico, tem sua luz natural ofuscada pela iluminação artificial, um dos índices do progresso técnico da realidade.

A incessante troca que existe no imaginário, entre as pulsões subjetivas e assimiladoras e as intimações objetivas que emanam do meio cósmico e social, é representada espacialmente no poema pelas relações dentro-fora. $\mathrm{O}$ olhar do sujeito lírico é atraído pelos elementos e situações do cotidiano da cidade que percorre e descreve: "lúbrica pessoa", "Sua excelência", "velha, de bandós”, “caixeiros”, que, “ao longo dos balcões de mogno", "plantas ornamentais" e "nuvens de cetins", dão o tom do elegante nos estabelecimentos comerciais, em suas atividades internas, não sem uma nuança de ironia: “Mas tudo cansa!". Na sequência dos passos perdidos, aos poucos, o olhar do sujeito lírico se volta para o exterior: os candelabros se apagam, as construções fulgentes se tornam mausoléus, a solidão e o silêncio se ouvem "Da solidão regouga um cauteleiro rouco"; e a presença da noite traz consigo o sentimento que o sujeito poético expressa ao encerrar a Parte III do poema: “Dó da miséria!... Compaixão de mim!”, conotando a compaixão humana ante a solidão e a miséria do mestre que já muito trabalhou e, a despeito disso, precisa esmolar para sobreviver em idade avançada.

Segundo Bachelard, “[...] o de dentro e o de fora não recebem de igual maneira os qualificativos, esses qualificativos que são a medida de nossa adesão às coisas. Não se pode viver da mesma maneira os qualificativos que correspondem ao de dentro e ao de fora. Tudo, inclusive a grandeza, é valor humano." ${ }^{101}$. O mundo exterior colhido pelos sentidos provoca sentimentos diversos no sujeito, que os expressa, no caso, através da lírica. No poema, da rua (fora) o sujeito ouve o ruído que vem do espaço interior (dentro) dos hotéis da moda, "um tinir de louças e talheres" (I-7), que ultrapassa os limites do dentro e do fora,

\footnotetext{
${ }^{101}$ BACHELARD, Gaston. La Poética del Espacio. México: Breviários del Fondo de Cultura Económica, 1965, p.254. (Tradução nossa)
} 
e cria uma atmosfera de final do dia. A varanda, espaço intermediário entre o "céu" e a "terra", onde "flutuam" os "querubins do lar", conota a elevação social pelo fausto e pela moda francesa, cuja imitação era "chic" na época. No mesmo plano físico, "as imorais" “Tossem, fumando sobre a pedra das sacadas." (IV-10) conota elevação dessas criaturas, que são equiparadas aos "querubins do lar" por estarem "sobre a pedra das sacadas", espaço de elevação e intermediário entre o dentro e o fora. Opõem-se aos "tristes bebedores" que "Nauseiam-me, surgindo, os ventres das tabernas" (IV-8), a autoridade, representada pelos "guardas que revistam as escadas", transitando no plano intermediário entre o alto e o baixo (escadas). Depreende-se daí que, se num primeiro momento parece haver oposição ente "querubins do lar" e "imorais", "tristes bebedores" e "guardas", num segundo momento a reflexão analítica ressalta a compaixão do sujeito poético que os coloca em pé de igualdade, pelo próprio ser humano que são.

Opressiva no cotidiano, "muralhas", "céu baixo", a cidade como um todo para o sujeito significa o dentro em relação aos "novos horizontes", que significam o fora, na existência. Reside aí, talvez, a grande diferença entre Cesário e Baudelaire. Diferente do flâneur francês, nosso poeta lisboeta partilha da dor humana: "Essa humanidade lisboeta não é a "multidão" moderna da metrópole baudelairiana, é apenas a "turba" de uma cidade portuária à margem da Europa, "à beira-mágoa", como diria mais tarde Pessoa." 102

O elemento acústico traz noções espaciais ora de vazio: "Um parafuso cai nas lajes, às escuras" (IV-2), conotando o silêncio da cidade pelo adiantado da hora; ora traz a noção de distância: “As notas pastoris de uma longínqua flauta”(IV-3). Às vezes, durante o seu caminhar a pé pelas ruas, o sujeito lírico se sente tão próximo do espaço da cidade que chega a fazer parte dela; outras vezes, afasta-se a ponto de ir buscar na distância a visão dos astros ou do mar. São exemplos disso no poema OSO, no primeiro caso, de proximidade:

\footnotetext{
${ }^{102}$ PERRONE-MOISÉS. Cesário Verde. Melhores Poemas. (Seleção .e Prefácio de Leyla PerroneMoisés). S P.:Global, p.13.
} 
“[...] as sombras, o bulício, o Tejo, a maresia “ (I-1), elementos espaciais locais, "Despertam-me um desejo absurdo de sofrer" (I-1), o anoitecer na cidade corresponde à melancolia no poeta, confundindo-se nos dois a relação de sujeito-objeto, indissociável, e a relação de causa-efeito.

Outras vezes, para tentar se libertar da angústia existencial, o sujeito busca na distância física ou temporal (da história /memória/futuro) um respiro ou uma saída. Da distância física, exemplificada com o texto, é: "Batem carros de aluguer, ao fundo" (I-3), ou seja, distante, não em primeiro plano em relação ao sujeito que fala, mas longe dele. Da distância espaciotemporal, o exemplo significativo da Parte I do poema é a sexta estrofe: “E evoco, então, as crônicas navais: / Mouros, baixéis, heróis, tudo ressuscitado! / Luta Camões no $\mathrm{Sul}^{103}$, salvando um livro, a nado! / Singram soberbas naus que eu não verei jamais!". Ante a angústia do presente, aceleradamente movido para frente pelo progresso, determinado pela ciência e técnica, cujo uso Portugal está defasado em relação a outras metrópoles da Europa e, por isso, sem saber muito bem qual o papel a desempenhar no futuro pela nação, o sujeito lírico busca, na história das conquistas "mouros", nas grandes navegações "baixéis" e na memória "crônicas navais" e no mito "heróis", a origem passada da existência humana em sua plenitude. Daí, o futuro (distante) ser projetado no presente (próximo). Além da referência aos filhos, que trarão nitidez às vidas, o sujeito lírico idealiza as mães e as filhas "Numas habitações translúcidas e frágeis". Na estrofe seguinte, o componente mítico: "Ah! Como a raça do porvir, / e as frotas dos avós, e os nômades ardentes, / Nós vamos explorar todos os continentes / E pelas vastidões aquáticas seguir!” (IV-4/5) e, em alusão ao episódio de "Os Lusíadas", no qual os navegantes portugueses e as ninfas de Tétis se entregam "aos afagos tão suaves, que ira honesta”, na Ilha dos Amores,

\footnotetext{
${ }^{103}$ Apud: SERRÃO, 2003. Conforme a publicação em Portugal a Camões (1880), versão que adotamos para este trabalho.

Na edição de Silva Pinto: Luta Camões no Sul, salvando um livro a nado! (1887)

Na segunda (1901) e terceira edição (1911): Luta Camões no mar, salvando um livro , a nado!
} 
recompensa de Vênus pelo êxito da Viagem às Índias, de que resultará um povo heróico, filho de homens e entidades divinas, que remete ao sagrado. Segundo Mircea Eliade:

O passado assim revelado é mais que o antecedente do presente: é a sua fonte. Ao remontar a ele, a rememoração procura não situar os eventos num quadro temporal, mas atingir as profundezas do ser, descobrir o original, a realidade primordial da qual proveio o cosmo, e que permite compreender o devir em sua totalidade. ${ }^{104}$

No poema OSO, o mito representa de um lado a direção ao futuro com base no passado de glória do povo português; de outro, a busca de totalidade do ser humano, fragmentado entre o presente materialista, da ciência e da técnica, e a espiritualidade original divina, de outro, representa, também, o poder criador: "Graças ao modelo exemplar revelado pelo mito cosmogônico, o homem se torna, por sua vez, criador." $" 105$

As cores resplandecentes e fulvas, que predominam nessas duas estrofes (IV-4/5) “translúcidas”, "ruivas”, “ardentes”, trazem a conotação do sol que ilumina e aquece a vida, e do fogo, elemento de purificação, no sagrado. Tal se repete nas imagens de "Um forjador maneja um malho, rubramente; / [...] / Um cheiro salutar e honesto a pão no forno" (III-4), nas quais a força do trabalho (que forja o ferro e assa o pão), no cotidiano, remete ao mito de Prometeu, Titã que roubou dos deuses o segredo do fogo e o entregou aos mortais, dotando, assim, a humanidade da luz da razão para criar as ciências e desenvolver a técnica, transformando deste modo o impossível no possível.

Se quanto à proximidade o caminhar a passos perdidos pelas ruas e becos lembra o labirinto, de que o escrever é o fio condutor de Ariadne; a distância dos "astros com olheiras", para os quais o sujeito ergue seu olhar, remete ao mito de Dédalo, em que a idealização e criação de asas permitiram sair das muralhas da cidade que o aprisionavam e

\footnotetext{
${ }^{104}$ ELIADE, Mircea. Mito e Realidade. São Paulo: Editora Perspectiva, 2006, p. 108.

${ }^{105}$ Idem, ibidem, p. 124
} 
buscar novos horizontes. Em ambos os mitos as alegorias de transcendência da realidade pela imaginação são evidentes.

Se de um lado "À vista das prisões, da velha Sé, das Cruzes," (II-2), símbolos da ordem e da religião, do poder instituído pela Monarquia e pela Igreja, portanto, provocam no sujeito lírico o sentimento de tristeza: "Chora-me o coração que se enche e que se abisma.” (idem), à lembrança das atrocidades cometidas por eles contra o ser humano, no passado histórico; de outro lado, os recintos populares "E as tascas, os cafés, as tendas, os estancos, / Alastram em lençóis os seus reflexos brancos; / E a lua lembra o circo e os jogos malabares.” (II-3) remetem à descontração e ao lúdico. A cor e a dialética do claro-escuro têm função preponderante nesse contexto: à "nódoa escura e fúnebre do clero" (II-4), que remete ao sofrimento e à condenação à morte pela Inquisição, contrapõem-se os "reflexos brancos" (II-3) dos iluminados locais de diversão, de conotação pagã (divindade-lua) e circense (jogos malabares).

A análise das relações espaciais de alto-baixo, dentro-fora, próximo-distante, bem como da dialética do claro-escuro, som-silêncio, sombra-luz põe em evidência a ideologia liberal de origem burguesa e moral cristã, predominante à época de Cesário, e a expressão contrária a isso é consoante aos temas realistas antiburgueses e anticlericais, que poeta o imprime nos versos de OSO.

Entretanto cabe aqui notar que a noção temporal de duração (do anoitecer à madrugada do dia seguinte), além de possibilitar a idéia de verossimilhança pela mudança de iluminação e das atividades no cotidiano da cidade de Lisboa, observadas e sentidas pelo sujeito lírico ao longo do percurso, permite a analogia com o momento histórico vivido por Portugal, no cenário ocidental. Citando Antônio Cândido:

Mas a visão realista só se completa graças ao registro das alterações trazidas ao pormenor pelo tempo, que pode ir de algumas horas até um 
século - e ao introduzir a duração introduz a história no cerne da representação da realidade. As coisas, os seres, as relações existentes na medida em que duram; por isso muito da sua especificação realista consiste em mostrar o efeito do tempo sobre os detalhes, mesmo porque a suprema especificação pode ser essa marca temporal. ${ }^{106}$.

Se entendido a partir daí, o poema revela aquele instante vivido pelos portugueses, em que o ingresso na era industrial, cuja técnica prometia o progresso (e a felicidade dele decorrente), já presente em outros países europeus, é ali tardio e nebuloso. Sem que ainda se realize ou se saiba com clareza o que de favorável ao individuo e à nação essa transformação propiciaria, tudo é indefinidamente noturno. Daí, o sentimento de angústia existencial expresso pelo poeta em "Dor humana". Longe, portanto, de conotar a liberdade do espaço aberto das ruas e praças, a cidade é prisão, como atestam os versos: "Muram-me as construções rectas, iguais, crescidas” (II-5), o que leva o sujeito a buscar, através do caminhar e do escrever, "novos horizontes" (IV-11), nova aurora. Nesse sentido, o tempo cronológico do poema $\mathrm{OSO}$, do anoitecer à madrugada do dia seguinte, pode ser entendido como metáfora de Portugal, que, na obscuridade do presente vivido, anseia e busca a luz de um novo amanhecer.

\section{CAMINHAR E ESCREVER}

Na medida em que, se definido como enunciação, o ato de caminhar permite entender sua tríplice função enunciativa: apropriação, realização e relação ao ato de escrever, e considerando as três características que as distinguem do sistema espacial, o presente, o descontínuo e o fático, podemos compreender melhor esta questão. O sujeito caminhante do poema atualiza a ordem espacial e, ao mesmo tempo, desloca-a e inverte

${ }^{106}$ CÂNDIDO, Antônio. Recortes. São Paulo: Companhia das Letras, 1993, p.124. 
com variações e improvisações da caminhada, a qual deixa de lado alguns elementos espaciais, enquanto privilegia outros. Visto por este prisma, o sujeito seleciona fragmentos espaciais, criando um descontínuo na trajetória da existência e moldando um percurso que passa a ser o presente espacial em relação ao sujeito, que se emociona a partir dele. Se, ao caminhar, o sujeito reorganiza o espaço, suas referências, modelos sociais, usos culturais e situações observadas no cotidiano; ao escrever, ele expressa sua emoção daí decorrente. Há, portanto, uma aproximação das formações linguísticas e processos caminhatórios. Em Certeau lemos:

Caminhar é ter falta de lugar. "É o processo indefinido de estar ausente e à procura de um próprio. A errância, multiplicada e reunida pela cidade, faz dela uma imensa experiência social da privação do lugar - uma experiência, é verdade, esfarelada em deportações inumeráveis e ínfimas (deslocamentos e caminhadas), compensada pelas relações e os cruzamentos desses êxodos que se entrelaçam, criando um tecido urbano, e posta sob o signo do que deveria ser, enfim, o lugar, mas é apenas um nome, a Cidade. ${ }^{107}$

Ao analisarmos o poema OSO, verificamos que o sujeito, ao observar, durante seu caminhar, trabalhadores braçais e burgueses, vendedoras de peixe e compradoras elegantes, ventre das tavernas e hotéis da moda, cais português e embarcações inglesas, monumento nacional e moda francesa, dentre outras situações, que vai apreendendo pelos sentidos, revela, através de pares dialéticos, modelos sociais e usos culturais, seu sentimento de revolta e sua angústia existencial. Se as sinédoques e os assíndetos expressam a fragmentação do espaço e o ritmo dos versos expressa o descontínuo no tempo, o caminhar e o escrever revelam a busca da totalidade. No que diz respeito à sinédoque, que consiste em designar o todo pela parte, através dela o poeta expressa a fragmentação. Por exemplo,

${ }^{107}$ CERTEAU, op. cit., Vol. 1, p. 183. 
a expressa pela gradação: "Madrid, Berlim, São Petersburgo, o mundo!" (I-3), capitais que "ocorrem em revista" para o sujeito lírico como mundo industrializado, para onde os "felizes", os que podem se livrar da opressão da cidade que sofridamente ingressa na era Industrial, se vão pela via "férrea". Em contraposição ao sentido de progresso pelo uso da técnica na indústria, está Lisboa, capital do país "atrasado" em relação aos citados, pelo uso da mão-de-obra, do trabalho braçal dos "mestres carpinteiros" rebaixados a "morcegos", ou seja, à condição animal, pela exploração da força de trabalho e outras humilhações, como, por exemplo, o maltrato do criado da casa à vendedeira de frutas e legumes no poema Num Bairro Moderno, dentre outros. A emoção expressa pelo ponto de exclamação “o mundo!" conota o desejo de evasão da angustiante Lisboa e a busca de novos horizontes (outros países). Vale aqui notar uma dupla fragmentação: do mundo em capitais e dos países em categorias de atrasados e adiantados com relação ao uso da técnica - promessa, então, de felicidade. Para melhor entender o sentimento do sujeito lírico, recorremos a Sartre:

[...] há emoção quando o mundo dos utensílios desaparece bruscamente e o mundo mágico aparece em seu lugar. Portanto não se deve ver na emoção uma desordem passageira do organismo ao espírito que viria perturbar de fora a vida psíquica. Ao contrário, trata-se do retorno da consciência à atitude mágica, uma das grandes atitudes que lhe são essenciais, com o aparecimento de um mundo correlativo, o mundo mágico. A emoção não é um acidente, é um modo de existência da consciência, uma das maneiras como ela compreende (no sentido heideggeriano de "verstehen") seu "serno-mundo". 108

Na medida em que o sujeito colhe, através dos sentidos, elementos da realidade externa, ele os elabora emocionalmente ao expressar seu sentimento. Para expressá-lo, lança mão do descontínuo (versos) e do fático (pontos de exclamação), entre outros

\footnotetext{
${ }^{108}$ SARTRE, Jean-Paul. Esboço para uma teoria das emoções. Trad. de Paulo Neves. Porto Alegre: LPM, 2007, p. 90.
} 
recursos de linguagem. No descontínuo, o sentido figurado da metáfora, do símbolo e da metonímia preenche vazios; no fático, a gesta ambulatória expressa as surpresas, imprevistos e reflexões. Por exemplo, a realidade externa "lojas tépidas" (III-2) colhidas pelo sujeito poético, através da visão e do tato, é expressa através da sinestesia, que funde os dois sentidos. A imagem de "filas de capelas" e "catedral imensa", iluminadas por "círios laterais" sugere uma atmosfera solene da catedral imaginada, onde a iluminação é a círios e não a gás, diferente da realidade presente no poema, na qual "o gás extravasado enjoa e perturba", conforme já vimos anteriormente. Em contraposição a essa imagem solene, o verso "o chão minado pelos canos" (III-3) descreve a realidade pedestre da cidade em transformação. O adjetivo "minado" atribui a "chão" a conotação de degradação do espaço físico da Lisboa percorrida pelo sujeito e a consequente tristeza dele: "Triste cidade!". A exclamação reforça faticamente a reflexão "mundo-eu" e "eu-mundo" no poema, conotando a não submissão do homem ao meio.

Quanto ao assíndeto, a supressão de conjunções e advérbios que são termos de ligação, corresponde, no ato de caminhar à prática da elipse de lugares conjuntivos, criando ausências. Se a sinédoque substitui a totalidade (cidade/mundo) por fragmentos (ruas, becos, edifícios, etc.), o assíndeto desfaz a continuidade e transforma o espaço contínuo em ilhotas separadas. Deste modo, o conjuntivo é substituído pelo detalhe: "balcões de mogno", "xale com debuxo" são exemplos de detalhes que conotam luxo; em contraposição a detalhes que conotam escassez ou excesso de trabalho. Exemplo de escassez é "um trôpego arlequim braceja numas andas" (I-8) indivíduo que se movimenta no espaço urbano sem ter o que fazer; e de excesso de trabalho, as "costureiras e floristas" a quem "custa-lhes elevar os seus pescoços altos", quase imobilizados pelo cansaço. Contrapõe-se, aqui, também o componente estrangeiro ao nacional, com desvalorização deste ante aquele: "mogno" e "debuxo" (madeira nobre do estilo inglês em uso e imitação 
da moda francesa no vestuário, características da riqueza da burguesia da época), e as “costureiras e floristas" (mão de obra explorada pelo capitalismo). Se àquele acompanha a expressão "entre luxo", estas são "quadros revoltados” (II-10). Tal revela uma visão de mundo contrária à ordem estabelecida.

É seu dom chegar a percepções refinadas como: “um parafuso cai nas lajes, às escuras" ou "os olhos de um caleche espantam-me sangrentos", conotando o silêncio da cidade despovoada noite adentro e o esforço e cansaço do animal ao fím do dia. "Diferenciando-se da cidade baudelairiana, Lisboa, na poesia de Cesário, ganha dimensões históricas. Por exemplo, nos versos: "ao tocar doente dos pianos" "o poeta adivinha nas burguesinhas solteiras que tocam piano o mesmo histerismo das antigas freiras" ${ }^{109}$. Não se pode deixar de ler aí a crítica social ao confinamento referente a estas e à ausência de noivos socialmente idôneos para casar com aquelas. Outro exemplo é perceber nas sombras de um templo o peso secular das tradições clericais e no trabalho dos mestres carpinteiros a denúncia da exploração da mão-de-obra dos operários urbanos. Na expressão “exíguas pimenteiras”, o adjetivo "exíguas" traz a conotação de míngua da natureza - em suas origens rurais - na capital voltada para o progresso técnico; e o substantivo "pimenteiras" remete às especiarias do oriente, cujo comércio enriqueceu Portugal no passado, idéia que não se estende ao presente do sujeito. Tal ironia ante a perda se faz presente na lírica de Cesário, como podemos observar, nos poemas de temática campestre, a exemplo de Flores Velhas, no qual o sujeito lírico, no início, ao se recordar do “jardinzinho agreste,/Aonde tanta vez a lua nos beijou”, vale-se da natureza farta, expressa em "flórido passado", que conota a presença da amada "Soberba como um sol, serena como um vôo", descrita através de imagens de luz e vida "sol", e de elevação "vôo", em oposição a "duas saudades roxas", flores que simbolizam a tristeza e ausência no presente,

\footnotetext{
${ }^{109}$ LOPES: op. cit. , p. 965.
} 
expressas pelo substantivo concreto "saudade", que remete ao próprio sentimento abstrato saudade. O adjetivo "roxo", cor que simboliza, na iconografia cristã, a Paixão, união completa de Deus com os homens, mediante sofrimento e morte, e nos costumes e canções populares muitas vezes simboliza a fidelidade, segundo Herder Lexikon ${ }^{110}$, e pelo numeral “duas", que perfaz o par amoroso desfeito no presente lírico, descrito como "vida triste e má", da qual "Os goivos, a baunilha e as rosas-de-toucar" são lembranças do "bom romance", e "As dálias a chorar nos braços dos jasmins" são imagens de tristeza e solidão. Aqui a ironia consiste na alteração de sentido atribuído às flores: de exuberância pretérita "flórido passado" à exiguidade presente representada por "duas saudades roxas", flores funéreas. Ainda, nessa mesma linha, o uso da ironia, expressa o sentimento de perda do sujeito, como se pode observar no poema Nós em que as imagens de fartura "montões de malva" predominam na imagem de ausência dos irmãos.

Entre a percepção das coisas e o sentido das coisas há traços e marcas sociais, da cultura e da história portuguesa, há índice da própria natureza humana em busca da transcendência de sua condição: "E eu que medito um livro que exacerbe, / Quisera que o real e a análise mo dessem" (II-5) são versos que expressam o desejo de transcender a realidade presente através da criação poética. As antinomias dialéticas revelam a fragmentação espaciotemporal, que, através do caminhar e do escrever, o sujeito busca totalizar, harmonizando em versos os contrastes dos ultrajes e glórias marcados pela história e pelas grandes narrativas com a transitoriedade da vida presente. Pelo percurso o sujeito, ao incluir a quarta dimensão, a do tempo, na descrição do espaço, expressa na poesia a dinâmica do olhar presente estendido ao passado e ao futuro. $\mathrm{O}$ cotidiano e o prosaico ganham força na lírica. Segundo Massaud Moisés, "Pela primeira vez, o lirismo tentava, com a força própria das novidades, lançar a atenção sobre o prosaico diário [..." 111

\footnotetext{
${ }^{110}$ LEXIKON, Herder, Dicionário de Símbolos. São Paulo: Cultrix, 1999, p. 208.

111 MOISÉS., Massaud. A literatura portuguesa. 35ª Edição. São Paulo: Cultrix, 2008, p .240.
} 


\section{III - LEITURAS DE MUNDO E FORMAS DE EXPRESSÀO}

"A mim o que me rodeia é o que me preocupa..."

$\left(\right.$ Cesário Verde) ${ }^{112}$

Articulado com os demais e com o eixo pelas escolhas temáticas e elementos estilísticos de que Cesário lança mão para compor sua obra poética, este capítulo é dedicado à análise de características impressionistas, enquanto expressão do cotidiano em relação com a existência, na obra de Cesário, a partir do poema $O$ Sentimento dum Ocidental.

A epígrafe desse capítulo remete a Ortega y Gasset quando ele afirma que a vida é uma dialética entre o eu e a situação em que ele se encontra - "eu sou eu mesmo e minhas circunstâncias". Sua negação de uma natureza humana fixa e seu foco na liberdade individual lembram o Existencialismo de que Sartre seria o maior expoente no após-guerra. Neste sentido, a poesia de Cesário Verde, ao expressar o cotidiano, sugere instantâneos do dia a dia na existência, através de imagens de luz, cor e movimento, que são características da pintura impressionista. Segundo Hauser, o impressionismo é uma arte urbana, e não só porque descreve a qualidade paisagística da cidade e traz a pintura de volta do campo para a cidade, mas porque vê o mundo através dos olhos do cidadão e reage às impressões externas com os nervos tensos do moderno homem técnico. A percepção sensorial de Cesário capta os efeitos da luz, do ar, da atmosfera de Lisboa, que expressa com palavras que pintam o fugaz, o dinâmico, o fragmentado, dando primazia ao momento e ao acaso. No poema OSO, a luz natural do anoitecer cede vez à iluminação artificial dos candeeiros e os encontros do sujeito poético com caminhantes, trabalhadores, boêmios, dentre outras figuras passantes, ao longo do percurso, reforçam as imagens do movimento e do efêmero.

${ }^{112}$ In: Carta a Silva Pinto, 1875. Apud: SERRÃO, 2003, op. cit., p. 203. 
Desse modo, o aqui e agora também serão critério de verdade do indivíduo; a ênfase no passageiro submete ao próprio domínio do estado de ânimo do sujeito as qualidades permanentes da vida. No poema OSO o estado de ânimo do sujeito “desejo absurdo de sofrer" vai se intensificando na medida em que a noite se aproxima. Assim, do sentimento individual ele se expande à "dor humana" expressa nos versos finais do poema. Também se observa esse movimento no poema Nós em que a dor da perda dos irmãos transborda e se constitui na dor provocada à população pelos males das epidemias.

O jogo de luz refletida e sombra iluminada representado na pintura pela técnica do pontilhismo é transposto à poesia pela descrição aparentemente descuidada, em versos justapostos que compõem os poemas. Exemplificamos com os versos: "Toda a maré luzia como escamas,/ Como alguidar de prateados peixes." (Noitada, E. 23).

Resultante de uma análise o Impressionismo constrói seus temas do cotidiano a partir dos sentidos, e na busca de uma imagem do todo, oferece-nos as partes de que é composto. Para Oscar Lopes, a dimensão realista e concreta não é mero descritivismo, mas uma visão crítica da sociedade, uma profunda reflexão sobre as condições sociais e psicológicas da produção econômica e a denúncia das frustrações históricas portuguesas: o sofrimento citadino n'O Sentimento dum Ocidental é histórico e não meramente decadente e literário. ${ }^{113}$ Retomam-se, portanto, aqui, o cotidiano e a existência; a objetividade e subjetividade, como linhas de força nas relações espaciotemporais, que se irradiam na obra.

Com o desenvolvimento do capitalismo e industrialismo de 1850 em diante, a vida cotidiana, os lares, os meios de transporte, as técnicas de iluminação, alimentação e vestuário sofrem transformações radicais. Aumenta a demanda de luxo e a mania de divertimento é generalizada. A boêmia, ponto de contato entre a intelligentzia e o proletariado, ganha a simpatia geral.Nesse contexto, o Naturalismo, que é estilo de pequena

\footnotetext{
${ }^{113}$ Apud. MENDES, Margarida Vieira: Op. Cit, p. 25.
} 
minoria, sofre ataques da Academia, da Universidade e dos críticos e torna-se mais hostil na medida em que o Realismo como atitude filosófica oposta ao idealismo romântico a ele se agrega. No plano estilístico o Impressionismo torna-se autônomo e faz sua primeira aparição coletiva, nas salas do fotógrafo Nadar, em Paris, em abril de 1874, e a existência ganha vida, cor e movimento nas telas a partir da perspectiva de um presente cotidiano. $\mathrm{O}$ tempo bergsoniano se constitui em seu elemento vital para captar o instante em sua experiência básica. No cerne da filosofia de Henri Bergson está a noção de duração, o tempo como imediatamente experimentado, em contraposição ao tempo objetivo, medido pelo relógio. Para ele, o movimento de duração é impelido por uma força vital, ou seja, criativa, que deriva mais da intuição que do intelecto, tornando cada momento qualitativamente único. Por este viés, depreendemos da poesia de Cesário que tudo contribui para a sugestão do instante, expresso como uma "pintura com palavras".

Na relação campo-cidade, as cores do campo podem ser outras, o ritmo de vida, mais lento. Mas, como afirma Maria A. Paschoalin ao se referir à poesia do autor:

Mas o campo, real, está incluído no mesmo sistema social que produz a cidade sem cores. Uma cidade onde a iluminação a gás se sobrepõe à luz das estrelas; onde a liberdade de movimentos foi contida pela geometrização do espaço; onde não se ouvem mais as notas pastoris longínquas, abafadas pela nova harmonia de sons de ferro e da pedra. Mesmo diferentes cidade e campo estão intimamente ligados, compõem a mesma sociedade. ${ }^{114}$

Acompanhando a crise do Positivismo e do Materialismo, o Naturalismo, ao longo da década de 80, entra em declínio e cede espaço a uma crescente reação idealista, de humanismo e misticismo. Desenvolve-se, então, um novo estilo, comum às diversas artes, que predominaria em toda Europa na última década do século XIX, com sobrepujança da

\footnotetext{
${ }^{114}$ PASCOALIN, op. cit., p.99.
} 
pintura, que emprestou às demais artes elementos e características que lhe eram próprios: a luz, a cor, o ar. Como fenômeno literário o Impressionismo é resultante do Realismo e Naturalismo. Entretanto, para o impressionista, importam mais as sensações e emoções que o objeto desperta no sujeito, num dado momento. Ao contrário do Realismo, no Impressionismo há colaboração da subjetividade. Citando: "O mais importante no Impressionismo é o instantâneo e único, tal como aparece ao olho do observador. Não é o objeto, mas as sensações e emoções que ele desperta, num dado instante, no espírito do observador, que é por ele reproduzido caprichosa e vagamente.” E, em continuação: "Não se trata de apresentar o objeto tal como visto, mas como é visto e sentido num dado momento." ${ }^{115}$. E, mais adiante: "No Impressionismo, o real é visto através de um temperamento, pelas sensações e impressões que desperta, num singular momento que passa. Ao transferir o registro das relações externas para o das internas, isto é, das impressões despertadas no espírito pelo contato com as coisas, cenas, paisagens ou pessoas, os impressionistas introduziram um novo mundo na literatura." 116

À luz dessa concepção, como exemplo, depreendemos dos poemas Cristalizações e Num Bairro Moderno o seguinte: poema publicado em 1878, "Cristalizações" confirma a capacidade de ver e comunicar quadros urbanos de modo impressionista. A expressão inicial do poema "faz frio" registra o banal e se desloca em imagens que traduzem sensações captadas de todos os sentidos: tato, visão, audição, paladar e olfato. Por exemplo, as expressões que remetem à luz "imensa claridade", "chão vidrento", "molhada casaria", em contraste com os quintais que "negrejam" sob o céu subitamente aberto. O grito das peixeiras, os cheiros com sabor de campo a que remetem as parreiras no último verso da terceira estrofe, os "choques rijos, ásperos, cantantes" das pedras quebradas pelos robustos calceteiros, que contrastam com a frágil "atrizita" de "pezinhos rápidos, de cabra”. Tudo

\footnotetext{
${ }^{115}$ COUTINHO, Afrânio. Introdução à Literatura no Brasil. 5a. ed. Rio de Janeiro: Editora Distribuidora de Livros Escolares, 1968, p.223.

${ }^{116}$ Idem, ibidem, p.223.
} 
anima o instante da cidade e da percepção que dela nos oferece o poeta nessas vinte quintilhas compostas de alexandrinos iniciais e decassílabos que reforçam a ideia do caminhar do sujeito lírico pelas ruas da cidade. Até as cores têm movimento de luz, como se lê na nona estrofe, indicando o instante que passa: "Negrejam os quintais; enxuga a alvenaria;/ Em arco, sem as nuvens flutuantes,/ o céu renova a tinta corredia;/ E os charcos brilham tanto que eu diria/ Ter ante mim lagoas de brilhantes!" Mesmo nos poemas citadinos há fugas para imagens campestres, ainda que pela ausência da existência delas na cidade, a exemplo do que se lê no início da quarta estrofe: "Não se ouvem aves! Nem o choro duma nora", o que remete à lavoura arcaica.

Nesse poema, cujo título plural "Cristalizações" remete a imagens fragmentadas pelo efeito da luz e da água, o realismo, longe de ser documental e pitoresco a registrar tipos curiosos da cidade, ou o realismo objetivo, doutrinário desse movimento, é um realismo lírico, um sentimento do real, um sentimento coletivo assumido como pessoal.

Os verbos, colocados no início dos versos, destacam o dinamismo das ações, assim como a profusão adverbial e a colocação sintática dos complementos circunstanciais antes dos núcleos nominais, por exemplo, "calceteiros" e verbal "calçam” causam a impressão do instante presente. A abundância das frases nominais e enumerativas, com predomínio da coordenação acentua a idéia de fragmentação e, por vezes, estabelece contraste entre elas. Por exemplo, os calceteiros "bovinos, másculos, ossudos" e a actrizita "que vacila, hesita, impaciente". Naqueles, evidenciam-se os traços épicos de força heróica "másculos"; nesta, os diminutivos "botinhas" e "pezinhos" remetem ao lírico. Constatamos, a partir daí, que aquilo que se costuma chamar "efeitos do real" concretiza a pequena narrativa - temporal e espacial - da aparição e atuação da atrizita no cenário da rua, como que a desempenhar papel numa peça. O ritmo dos versos finais do poema traduz a rapidez dos passos curtos saltitantes a atravessar "Covas e entulhos, lamaçais, depressa/ Com seus pezinhos rápidos, 
de cabra!". A metáfora "cabra" - animal do campo - contrasta com a cidade evocada na imagem "sítios suburbanos, reles!" rebaixando, por um lado, tanto eles "bovinos" como ela, "cabra", à condição de animais rurais, como a cidade à insignificância "reles"; e, por outro lado, denunciando a sobrecarga e exploração do trabalho na urbe: eles "homens de carga", ironicamente tratados por "bons trabalhadores", na estrofe dezessete, e ela "a tiritar em suas peles", ou seja, com carência de agasalho ante o frio do inverno "dezembro enérgico". Ambas as imagens de reforço do sacrifício e da luta do povo português, com quem o poeta se mostra solidário, sintetizadas na décima quarta estrofe: "Povo! No pano cru rasgado das camisas/ Uma bandeira penso que transluz!/ Com ela sofres, bebes, agonizas:/ Listrões de vinho lançam-lhe divisas, / E os suspensórios traçam-lhe uma cruz!”

No poema Num Bairro Moderno (1877), o cotidiano e o percurso descritos pelo sujeito lírico a caminho de casa para o trabalho trazem o dia a dia lisboeta aos olhos do leitor através de imagens verbais, que traduzem a estética impressionista por palavras e expressões conotativas da incidência da luz, da cor, do movimento e da forma, quais impressões da realidade captadas num determinado momento. Por exemplo: os decassílabos da quintilha inicial do referido poema “Dez horas da manhã; os transparentes/ Matizam uma casa apalaçada;/ Pelos jardins estancam-se as nascentes,/ E fere a vista, com brancuras quentes,/ A larga rua macadamizada." dão a impressão do real de uma cena da vida cotidiana, a plein air. Nessa estrofe, a menção do horário matutino pela locução adverbial “dez horas da manhã” remete à claridade natural do dia; os substantivos "transparente, nascentes e brancuras" nominam o efeito da intensidade da cor branca, que, ao mesmo tempo em que busca mostrar os objetos (interior da casa apalaçada e larga rua), esconde sua forma, pois aqueles "matizam" e o brilho destas "fere a vista", impedindo de ver bem as coisas. Os verbos matizar e ferir conotam a ação do movimento da luz solar que causa efeito tanto na vista do sujeito lírico "fere" quanto no detalhe do objeto observado 
"rua macadamizada". Assemelha-se, aqui, a descrição do sujeito poético à técnica do pontilhismo, desenvolvida pelos pintores impressionistas, ou seja, a um conjunto de pinceladas que súbito se organiza e ganha vida diante dos olhos do espectador. No poema, tal efeito é traduzido em imagens verbais pelas sinestesias fere a vista e brancuras quentes (visão e tato) que sugerem o brilho e o calor, atributos do sol, elementos naturais incontroláveis, em oposição aos jardins e à casa apalaçada, artificialmente projetados para serem controlados pelo ser humano em sua ânsia de organizar o bairro e a cidade para fins administrativos e segundo a ideia de "progresso", a exemplo de outras capitais européias da época. Para tanto, as "nascentes", cuja água representa a fonte emanente e continua de vida, “estancam-se”, cessam. Nesse sentido o poema Num Bairro Moderno remete à ideia de desnaturalização do meio ambiente pelo urbano, bem como à de desvitalização pela artificialidade da técnica, temática recorrente na obra poética de Cesário Verde.

\section{RELAÇÃO ARTE-REALIDADE}

O desejo de se livrar da opressão da cidade em processo de metropolização, em que se encontra Lisboa, fragmentada, no presente do sujeito lírico de OSO e no restante da obra como um todo, leva-o a buscar saída de diversos modos: pelo espaço geográfico representado por outros países "Madrid, Paris, São Petersburgo, o mundo!” (I-3) ou pelo campo; pelo espaço mental e físico "a cismar" e "erro pelo cais" (I-5); no tempo histórico, representado pelas “crônicas navais” (I-6); na literatura, pela alusão a "Os Lusíadas” (I-6); no sonho, que se torna pesadelo "Cólera e Febre" (II-7); no mito, que se refere à "raça ruiva do porvir" (IV-6). Entretanto, é através do processo de criação artística que o sujeito lírico reitera várias vezes o desejo de libertação, saída da opressão citadina: “E eu, de luneta de uma lente só, / Eu acho sempre assunto a quadros revoltados:” (II-11). Essa tensão, que no 
poema analisado se configura entre opressão e desejo de libertação do sujeito poético, é um dos traços da poesia moderna, que segundo Hugo Friedrich:

Essa tensão dissonante da poesia moderna exprime-se ainda em outro aspecto. Assim, traços de origem arcaica, mística e oculta, contrastam com uma aguda intelectualidade, a simplicidade da exposição com a complexidade daquilo que é expresso, o arredondamento lingüístico com a inextricabilidade do conteúdo, a precisão com a absurdidade, a tenuidade do motivo com o mais impetuoso movimento estilístico. São, em parte, tensões formais e querem, freqüentemente, ser entendidas somente como tais. Entretanto, elas aparecem também nos conteúdos. ${ }^{117}$

Tal é o caso, para fins exclusivos de análise, sabendo-se indissociável no universo artístico a forma-conteúdo, da alucinação (conteúdo) que o sujeito lírico expressa em OSO, através dos quartetos mistos, um verso decassílabo e três alexandrinos, (forma) que mantêm a isometria ao longo de todo poema. Na Parte I do poema, a busca de saída pela literatura parece frustrar-se ante a impossibilidade de imaginar, contida no verso: "Singram soberbas naus que eu não verei jamais!” (I6). Na Parte II, o sujeito lírico parece insinuar a expressão pictórica ao observar "de luneta de uma lente só", ou seja, examinar microscopicamente, ao gosto do cientificismo da época que, segundo A. Moles ${ }^{118}$ inaugurou a crença na ciência, em oposição à fé, "ciência do certo", a própria realidade: "Eu acho sempre assunto a quadros revoltados". Na Parte III, ele enuncia o desejo de escrever: "E eu, que medito um livro que exacerbe, / Quisera que o real e a análise mo dessem;" (III-5). Na Parte IV, a busca de uma saída do ambiente urbano que o oprime dá-se no plano existencial: "Enleva-me a quimera azul de transmigrar", verso que conota devaneio pelo verbo "enleva", e criação literária, pela "quimera azul”, referência à tinta de

\footnotetext{
${ }^{117}$ FRIEDRICH, Hugo. Estrutura da Lírica Moderna: da metade do século XIX a meados do século XX. Trad.: Marise M. Curioni. São Paulo: Duas Cidades, 1978, p.16.

${ }^{118}$ MOLES, Abrahão. A Criação Científica.
} 
escrever, ou seja, "de compor versos no papel." (IV-1). Em seguida, a associação das "linhas de uma pauta" à "dupla correnteza das fachadas", também remete ao ato de escrever as notas musicais na pauta, e aos "círios de capela", pela ordenação paralela que sugerem. E, finalmente, ante a realidade concreta e penosa da cidade, representada como “massa irregular de prédios sepulcrais, com dimensão de montes”, que aprisiona, a abstração dos "amplos horizontes" remete à idéia de liberdade, embora haja a consciência do sujeito poético que "a dor humana busca / E tem marés de fel, como um sinistro mar."

Lembrando que "Na criação lírica, ao contrário [da épica], metro, rima e ritmo surgem em uníssono com as frases. Não se distinguem entre si, e assim não existe forma aqui e conteúdo lá." ${ }^{119}$, cabe aqui, a partir de uma visão panorâmica da métrica cesariana, que prima pelo rigor parnasiano, que tende à procura da confecção perfeita dos versos, pela regularidade métrica, estrófica e rítmica, ressaltar dois poemas, cuja análise estilística denota um processo de maturação da lírica cesariana. A avaliação estilística das opções métricas de Cesário denota a diversidade combinatória dos dois metros, alexandrino e decassílabo, sendo os poemas Humilhações e De Verão importantes exemplos do momento de maturação da modernidade poética de Cesário, em que o casamento forma-conteúdo dá o tom de cada poema. Naquele, os três primeiros versos dos quartetos são alexandrinos, e o último, decassílabo; neste a relação se inverte, sendo o primeiro verso dos quintetos alexandrino e os quatro seguintes decassílabos, contribuindo, assim, a irregularidade métrica para o efeito de sentido singular de cada poema, um dos traços marcantes da modernidade. Tal indício já pode ser observado no poema Cristalizações (1879), composto por vinte estrofes de cinco versos cada, com a rima $\mathrm{ABAAB}$, sendo o primeiro verso alexandrino e os outros quatro decassílabos. Esta introdução às quintilhas, feita por um verso de doze sílabas, atribui ao poema um ritmo especial, que ora se concilia com a

\footnotetext{
${ }^{119}$ STEIGER. Op. Cit. p. 26.
} 
condição climática e a situação do tempo, ora se quebra em frases exclamativas que introduzem aspectos particulares dos trabalhadores: "A sua barba agreste! A lã dos seus barretes!"; "Homens de carga! Assim as bestas vão curvadas!” E nesse "dia frio, de imensa claridade crua" vão aparecendo os "calceteiros terrosos e grosseiros", "as peixeiras descalças" "a dar com os rins", "os rapagões" "que partem penedos", os "valadores" que atiram terra com largas pás". E estes homens, "filhos das lezírias, dos montados", "filhos da planície" ou "das montanhas", do campo, portanto, com saúde de ferro e atitudes de macho, opõem-se à fragilidade da "actrizita", uma figura feminina delicada, citadina, com rostinho estreito, friorento, que passa por ali vacilante para seu ensaio, atravessando "covas, entulhos e lamaçais", num casaco à russa e botinas de tacões agudos, semelhantes "a pés de cabra". Tanto em um caso como em outro, os verbos de ação conotam o movimento necessário para vencer o frio. $\mathrm{O}$ mesmo se dá com as peixeiras que marcham agitando os quadris e gritam. No tempo presente os verbos descrevem a ação e o som perpassa nítido através do ritmo das estrofes, às vezes pela contraposição ausênciapresença dele, como por exemplo: "Não se ouvem aves; nem o choro duma nora!/ Tomam por outra parte os viandantes;/ E o ferro e a pedra - que união sonora! /Retinem alto pelo espaço fora, / Com choques rijos, ásperos, cantantes.” (E.4)

Sobre o ritmo, valemo-nos de Otávio Paz, quando diz: "O poeta encanta a linguagem por meio do ritmo. Uma imagem suscita outra. [...] O poema é um conjunto de frases, uma ordem verbal, fundados no ritmo.“ ${ }^{120}$. Se a fragmentação em estrofes e versos é elemento constituinte do poema, o ritmo, ao provocar uma expectativa, produz um anelo. As imagens verbais expressam o movimento alternado entre opressão e desejo de liberdade no cotidiano, representando o contínuo na existência. Neste caso, o movimento de retração e expansão do sujeito lírico equivale à semelhança de sístole e diástole à pulsão da vida. No

${ }^{120}$ PAZ, 1982, op. cit., p.68. 
poema OSO, o ritmo se altera na fusão dos sextetos nos alexandrinos e à cesura variada dos decassílabos de que é constituído. Ao heroísmo comum da oitava rima de herança clássica substituem os quartetos populares, em que o cotidiano e a oralidade, num jogo temático, transformam o herói épico daquela no homem ordinário, sobrevivente ao dia a dia destes. Não há repetições em vão. As variações do andamento expressam intensidades do sentir diferentes da regularidade dos passos, o que, de certo modo, possibilita ao leitor a noção do espaço físico e do espaço da emoção, do sentimento. Citando Óssip:

O ritmo como termo científico significa uma apresentação particular dos processos motores. É uma apresentação convencional que nada tem a ver com a alternância natural nos movimentos astronômicos, biológicos, mecânicos, etc. O ritmo é um movimento apresentado de uma maneira particular. ${ }^{121}$

O ritmo marcado pela luz e sombra do dia e da noite marca o ciclo solar natural em OSO. O ritmo dos passos na cidade ou no campo marca o continuar na existência. Nesse sentido, verbos no presente do indicativo reforçam a idéia de movimento do sujeito no espaço. Por exemplo: "saio", “erro", “embrenho-me”, "sigo", denotam um deslocamento físico, uma ação. Por outro lado, os verbos "ocorrem-me", “chora-me”, "lembram-me”, “enleva-me”, "julgo", remetem a uma atitude interior do sujeito. Do mesmo modo, o ritmo da natureza está presente em outros poemas, como é o caso de Provincianas, como observamos nas expressões: “Como amanhecer", "Nessa manhã”, “Bom sol!”, “ao meiodia", denotando período do diurno, ou "inverno"” "outono", designando as estações do ano, com suas paisagens "vagas dum verde garço" e atividades características: os grãos e as sementes "acordam", "cresce o relevo dos montes", "fartam-se as vacas", "produz as novas

${ }^{121}$ BRICK, Óssip. Ritmo e sintaxe. Teoria da literatura - formalistas russos. Trad. Bras.Ana Mariza R. Filipouski e outros. Porto Alegre: Globo, p. 132. 
manteigas", referindo-se ao trabalho humano. Se o anoitecer na cidade desperta o sentimento de melancolia no sujeito, o amanhecer no campo deflagra sua alegria. A claridade do sol, mesmo nos poemas de temática citadina, dá tom de vigor aos versos. Por exemplo, Num Bairro Moderno, em que o sol é "o intenso colorista" (E.7), capaz de transformar vegetais em ser humano, na visão de artista do sujeito lírico. E, no mesmo poema: "E o sol estende, pelas frontarias, / Seus raios de laranja destilada." (E.18), as imagens de alto teor impressionista contribuem para os efeitos da luz nos elementos espaciais da cidade.

Diversamente do meio natural, de farta insolação, o meio técnico sofria de precariedade. Segundo Joel Serrão, em 1848, são acesos em Lisboa os primeiros candeeiros a gás. Em 1871, no Concelho de Lisboa, havia já 3080 candeeiros. "Mas a noite, a antiga e persistente noite, só será vencida de vez pela luz elétrica, o que levará seu tempo. A princípio (1878), só na via pública, [...]. Levará tempo a sobrepor-se à iluminação a gás, cujos restos ainda hoje existem nos bairros velhos de Lisboa." ${ }^{122}$ Em 1878, Cesário nos dá o "Quadro dum que à candeia / Ensina o filho a ler...?", documento histórico de excepcional valor de que a candeia de azeite continuava a iluminar a noite. A luz do gás torna-se obsessão em sua poesia. Por exemplo, nos versos a seguir: "E em breve ao quente sol e ao gás alvejará!" (Ironias do desgosto, 1875. E.7); "Nas ruas a que o gás dá noites de balada" (Merina, 1878. E.1); "Entre um saudoso gás amarelado" (Noitada, 1879. E.1); “O gás extravasado enjoa e perturba," (OSO, 1880. E.2).

O próprio som da palavra gás sugere algo que escapa; e a sequência de sons $a$ e $l$ nas palavras balada e amarelado, bem como as vogais que intercalam as sibilantes em extravasado, sugerem lentidão e monotonia. Um ritmo lento. Valendo-nos aqui, por transposição, das expressões com que Milton Santos se refere à má distribuição do uso da

\footnotetext{
${ }^{122}$ SERRÃO, Temas Oitocentistas. Vol. I. Lisboa: Livros Horizonte, 1978 p. 149.
} 
técnica no mundo atual, podemos dizer que a precariedade da iluminação técnica da Lisboa de Cesário também fazia dessa capital um espaço opaco em relação ao espaço luminoso de outras capitais europeias da época, o que se reflete na angústia do sujeito, no texto.

\section{RELAÇÕES SOCIOESPACIAIS NA OBRA POÉTICA}

À luz da ideia de Heráclito, como sugere Arnold Hauser, o homem não mergulha duas vezes no rio da vida, em eterno movimento para diante. $\mathrm{O}$ sujeito lírico de $O$ Sentimento dum Ocidental vai captando ao longo do percurso a pé pelas ruas de Lisboa as diversas cenas do cotidiano, em momentos diversos do anoitecer ao amanhecer, que o remetem a um outro espaço-tempo. Através da iluminação da cidade, o tempo cronológico pode ser observado: na Parte I, o fim de tarde e anoitecer; na parte II, o acender dos lampiões, na Parte III, as avenidas e as casas comerciais iluminadas opõem a noite natural à noite técnica; e, na Parte IV, a escuridão dos becos e corredores denota o adiantado da madrugada silenciosa e vazia. São recortes da realidade, difusos e detalhados, quase sempre sem contorno nítido que o sujeito vai captando com os sentidos apurados por onde passa, à semelhança das pinturas impressionistas, que buscam captar o instante e o impreciso da luz em seu contraste com a sombra. O uso dos substantivos que nominam formas e dos adjetivos indicadores de cores, associados aos advérbios de tempo, expressa nos versos cesarianos vestígios do real e da imaginação. Ruas, casas, pessoas, campo, cidade, trabalhadores, deambulantes, ao serem descritos em sua realidade exterior, significam, conforme o grau de luminosidade, os efeitos que causam no sujeito poético. Os versos "E o fim da tarde inspira-me; e incomoda! (OSO I-7), e "Reluz, viscoso, o rio, apressam-se as obreiras" (idem, E. 9) são exemplos de sombra (fim da tarde) e claridade (reluz) que expressam a impressão fugaz. 
Entretanto, diferentemente do pintor que, de um ponto fixo trabalha com o movimento da luz, Cesário, no poema em causa, trabalha com duplo movimento, ou seja, movimento dos passos e movimento da luz. Simultaneamente, o espaço a partir da rua, por onde caminha o sujeito lírico, e a transformação da luminosidade natural (do sol que se põe, cedendo lugar ao anoitecer) em luminosidade artificial (iluminação a gás, noite adentro) são percebidos e evocam a natureza ímpar do momento.

Ao registrar a passagem da noite natural à noite técnica, há uma alusão ao indício do processo de modernidade em que Portugal ingressava atrasado e lentamente. A partir daí, torna-se mais clara a compreensão de que o percurso do sujeito, do anoitecer à madrugada do dia seguinte, é uma alegoria da nação portuguesa, que vive entre a decadência em que se encontra (anoitecer) e a busca da esperança idealista que a move (amanhecer). No contexto, o individual cede espaço ao coletivo e ao existencial.

Com o declínio do Naturalismo, acompanhando a crise do Positivismo e do Materialismo ao longo da década de 1880, o Impressionismo adquire importância nas artes ocidentais e a pintura acaba por emprestar suas próprias características e elementos, o ar, a luz, a cor. Como fenômeno literário, sua gênese dá-se no Realismo e Naturalismo, pela reprodução da realidade, entretanto, ao contrário do realista-naturalista para quem o objetivo, exato, minucioso e impessoal constituía a norma, para o impressionista importa a impressão que a realidade provoca no espírito do artista, no momento em que se dá a impressão. Citando: “O mais importante no Impressionismo é o instantâneo e único, tal como aparece ao olho do observador." E, continuando: "Não é o objeto, mas as sensações e emoções que ele desperta, num dado instante, no espírito do observador, que é por ele reproduzido caprichosa e vagamente. Não se trata de apresentar o objeto tal como visto, mas como é visto e sentido num dado momento" ${ }^{123}$. Há colaboração do subjetivismo e esse

\footnotetext{
${ }^{123}$ COUTINHO, 1968, op. cit., p.223.
} 
é um dos elementos que os diferenciam. Importam as impressões despertadas no espírito do sujeito pelo contato com as coisas, cenas, paisagens, pessoas, num dado instante. Daí: “A técnica impressionista, "pontilhismo", ou pintura com palavras, captando a realidade não em estado de repouso, mas nas impressões e no conhecimento afetivo de aspectos e partes do real." ${ }^{124}$ As exposições de pintura impressionista foram entre 1874 e1886, embora viessem de mais longe os sinais dessa renovação na arte. Pissarro (1830-1903), Manet (1832-1883), Degas (1834-1917), Monet (1840-1926), Renoir (1841-1919); Rodin (18401917) na escultura; Debussy (1862-1918) e Ravel (1875-1937) na música.

\section{IMAGENS IMPRESSIONISTAS NA EXPRESSÃO VERBAL}

Dos 40 poemas de Cesário Verde, 20 têm características impressionistas marcantes. Tal referência ao pictórico se apresenta pelo uso metafórico de palavras como pintor, pintura, quadro, cores, disseminadas na obra, conotando uma relação entre escrever e pintar, enquanto criação, como os versos seguintes demonstram: "Pinto quadros por letras, por sinais", (Nós, E.29); "Em todo o caso dava uma aguarela." (De Tarde, E.1); "Eu acho sempre assuntos a quadros revoltados:" (OSO, II-22); "Achava os tons e as formas." (Num Bairro Moderno, E.9); "urdia estes fáceis esbocetos" (A Débil, E.12). Ou, ainda, pela estrofe que se segue: “[...] Eu mal esboço o quadro /Da lírica excursão, de intimidade. /Não pinto a velha ermida com seu adro; Sei só desenho de compasso e esquadro," (De Verão, E.2), na qual as palavras esboço, pinto e desenho remetem diretamente ao pictórico.

Apresenta-se, também, por meio dos substantivos e adjetivos na descrição de imagens visuais, da parataxe e da própria simetria de composição dos poemas. O número de versos, de imagens, quantidade de estrofes, de forma geral, é equilibrado na obra como

\footnotetext{
${ }^{124}$ Idem, ibidem: p. 224.
} 
um todo, revelando que Cesário geometriza seus poemas, dando preferência ao número par de estrofes, o que pode significar a busca de equilíbrio sugerida pelo número 2 . Acerca disso, Jorge Luiz Antonio procedeu ao levantamento, adotando a numeração utilizada na obra "Obra Completa de Cesário Verde”, organizada por Joel Serrão, que nos auxilia conferir o total de seis sonetos, dois poemas em tercetos, vinte e sete poemas em variados números de quadras, seis poemas em quintetos e um poema em sexteto. Constitui exceção um poema de 24 estrofes compostas de quadras e dueto.

Nessa mesma linha, há preferência por um determinado número de sílabas métricas no poema. Metro e sintaxe vão colaborar para uma expressão sóbria, calculada e antioratória. O próprio conteúdo do poema se apresenta como quadros, cenas, recortes/imagens. Por exemplo, em Cristalizações, conferimos 45 imagens-versos ou imagens-frase justapostas, em planos, como uma pintura das inúmeras facetas da realidade urbana portuguesa de seu tempo: "Faz frio. Mas depois duns dias de aguaceiros,/ Vibra uma imensa claridade crua. / De cócoras, em linha, os calceteiros, / com lentidão, terrosos e grosseiros, / Calçam de lado a lado a longa rua." (Cristalizações, E.1). A descrição da rua pobre, no dia frio, enquanto caminha, contextualiza os homens inseridos no ambiente, no cotidiano. A aliteração e assonância do último verso, pela repetição de sons consonantais (1, $\mathrm{m}, \mathrm{n})$ e vocálicos $(\mathrm{a}, \mathrm{o})$ reforçam a lentidão do gesto dos calceteiros e do movimento do sujeito que os observa trabalhar. Compreendemos daí que a poesia de Cesário busca o efeito da pintura impressionista de captar o instantâneo na luz e no movimento. Jorge de Sena, sobre as concentrações expressivas de Cesário, considera:

Efectivamente, os seus poemas, como poemas, não são impressionistas, segundo é costume considerar-se que o seja qualquer notação, subjetivamente adjetivada, de um pormenor ou de um aspecto da realidade objetiva. Impressionistas são (numa acepção distinta, ainda que paralela, da que se aplica ao impressionismo-escola-de-pintura) as suas 
imagens, ou mais exactamente, a descrição sintética dos "instantâneos" que ele distribui pela composição rigorosamente parnasiana de seus quadros"125

No poema Contrariedades, publicado em “O Livro de Cesário Verde” (1887), com 17 quadras, 68 versos (de 12 sílabas métricas do primeiro ao terceiro e de 5 o último de cada estrofe) encontram-se múltiplas imagens que se apresentam como num filme. Em cada estrofe, à exposição contida nos três primeiros versos (longos), segue-se uma breve conclusão, emitida no quarto verso. Por exemplo: "Sentei-me à secretária. Ali defronte mora/ Uma infeliz, sem peito, dos dois pulmões doentes; / Sofre de faltas de ar, morreramlhe os parentes/ E engoma para fora." Se, num primeiro momento, sujeito se aproxima da engomadeira tísica pela desventura, pelo desgosto da não publicação de seus versos, em seguida, dela se afasta, ao projetar no futuro a possibilidade de encontrar algum editor que pague todas as suas obras. Ao longo do poema, há uma alternância entre o sujeito e a engomadeira, a rua, a raiva, a crítica literária e a metalinguagem, uma explosão de sensações que resulta na crítica objetiva e no julgamento moral da sociedade contemporânea, sintetizada no último verso do poema: "Que mundo! Coitadinha!”. O próprio título do poema Contrariedades remete às impressões fragmentadas sobre um fato do cotidiano: a rejeição de um folhetim à publicação dos versos do poeta.

Em Manhãs Brumosas ((1877), poema composto de cinco sextetos com versos de 12 sílabas métricas, a descrição de um retrato de mulher é construída com imagens pictóricas impressionistas. As cores percorrem o poema como se ele fosse uma pintura do instantâneo. O gesto da mulher "Põe o chapéu ao lado, abre o cabelo à banda" provoca no sujeito uma impressão "Lembra-me uma pastora audaz da religiosa Irlanda". A voz da mulher evoca sensações sinestésicas, confusas, que a presença da mulher traz ao sujeito, como identificamos através das expressões difusas: "névoa azul”, "a caça", "as pescas", "os

\footnotetext{
${ }^{125}$ Apud: ANTONIO, Jorge Luiz. Op. Cit., p.68.
} 
rebanhos". A presença das brumas na manhã é descrita pelo olhar do sujeito e pelas sensações que ele provoca em seu íntimo, como expressam os versos: "Uma pastora audaz da religiosa Irlanda", "cujo amor me causa tanta pena." (E.5). As frases entrecortadas produzem um efeito que lembra o pontilhismo. A abundância dos substantivos demonstra a preocupação com a síntese: "E as redes, a manteiga, os queijos, as choupanas." (E.1): aparecem intercalados com cores na segunda estrofe, sugeridas pelo azul e prata da "névoa" e "pescas", e pelo marrom sugerido por "caça" e "rebanhos", suscitando o diálogo da terra (marrom, opaca, inferior) com o céu (azul, luminoso, superior). Desse modo, as imagens do cotidiano rural são construídas verbalmente no poema pelo sujeito que expressa através das palavras as cenas em movimento que passam por sua mente, através de metáforas, uma situação onírica: “O meu desejo nada em época de banhos, / Se as minhas mágoas são, mansíssimas ovelhas, / Correm os seus desdéns, como vitelos brancos." (E.4). Cesário nos revela em seus poemas o que vê e o que sente. Tal nos remete a Jorge Luiz Antonio, quando ele pondera: "Não foi à toa que Fernando Pessoa o considerou um dos três mestres da Modernidade, ao lado de Antero de Quental e Camilo Pessanha, com os quais Cesário Verde mostra algumas semelhanças.". E, a seguir, complementa: "Nessa construção sintética, e nesse apoio nas artes plásticas, é que parece residir o aspecto inovador e prenunciador da poesia modernista, razão por que até hoje Cesário é lembrado, citado, seguido e lido." 126

A própria temática explorada na obra poética como um todo se compara à da obra pictórica impressionista, quando esta busca captar os movimentos, como, por exemplo, sugerem os poemas: os retratos femininos emergentes (A Forca, Merina, Lúbrica, Esplendida); a crítica social (Desastre, Cristalizações) e a sátira (Heroísmos); as paisagens urbanas instantâneas (Num Bairro Moderno, Esplêndida, O Sentimento dum Ocidental,

\footnotetext{
${ }^{126}$ ANTONIO. Op. Cit. p., 288.
} 
Contrariedades); as paisagens rurais movediças (De Tarde, De Verão, Nós), para citar alguns entre outros poemas.

Acerca do Impressionismo Sir Ernst Gombrich lembra: "As novas teorias não diziam respeito somente ao tratamento de cores ao ar livre (teen haver), mas também ao das formas em movimento." 127 Tal mobilidade é evidente nos versos: “Com seus passinhos curtos e em suas lãs forrada." (Merina, E.2); "Carros de mão que chiam carregados" (Cristalizações, E.8); "No seu dorso feroz vou blasonar," (Heroísmos, E.3); "Sobem a trote a Rua do Alecrim" (Esplêndida, E.2); "Regressam os rebanhos das pastagens," (De Verão, E.5).

Sobre os artistas do impressionismo pictórico, Pierre Francastel pondera:

[...] a sua originalidade faz-se sentir na descoberta de novas atitudes psicológicas e estética, mais do que na invenção de não se sabe que misteriosa receita. É, portanto, indispensável tentar fazer um estudo precioso das relações existentes entre os pintores impressionistas e o meio literário e filosófico de seu tempo. ${ }^{128}$

É nessa linha que o Impressionismo acontece na poesia realista de Cesário. Para tanto, além dos autores citados, recorremos às características da literatura impressionista, que, segundo Addison Hibbard, em seu livro "Writers of the Western World "129 podem ser resumidas do seguinte modo, para fins de análise comparativa com a poesia de Cesário:

- registro de impressões, emoções, sentimentos despertados no artista, através dos sentidos, pelas cenas, incidentes, caracteres. Em vez da coisa, a sensação da coisa; - ênfase na revelação do momento. Importa a essência do momento, do

\footnotetext{
${ }^{127}$ GOMBRICH, Ernst.. Revolução Permanente: O século XIX. A História da Arte Trad. Álvaro Cabral. 16. ed. RJ; LTC, 1999, pp. 517.

${ }^{128}$ FRANCASTEL, Pierre. O Impressionismo. Trad. Maria do Sameiro Mendonça (até p.80) e Rosa Carreira (a partira da p. 80). São Paulo: Martins Fontes, 1988. p.113. Original:L'Impressionisme. Paris, Éditions Denoël, 1974, ${ }^{129}$ In: COUTINHO, Op. Cit., p. 225.
} 
incidente ou da paisagem interpretada pela alma do artista;

- valorização da cor, dos efeitos tonais, a atmosfera. Fragmentação e detalhamento. Percepção visual do instante;

- reprodução de emoções, sentimentos, atitudes individuais. É a vida interior em seus variados matizes que interessa pintar (descrever);

- a verdade do impressionista é a sua verdade num determinado momento. A vida em mudança constante, a captação do instantâneo;

Em suma, importam mais que os acontecimentos o deleite das sensações e emoções criadas. A atmosfera, qualidades tonais, impressão do vago, difuso, obscuro, sem sentido, começo ou fim. Efeito. E, ao cotejarmos com a análise da obra de Cesário, tendo por núcleo o poema OSO, verificamos os traços preferenciais de estilo, sintaxe, figuras, cuja constelação e não o uso isolado caracteriza o Impressionismo, os quais resumimos abaixo:

- impassibilidade e impersonalidade, mesmo nas notações subjetivas, visando à captação objetiva das percepções sensoriais e instantâneas;

- sintaxe esquemática, oposta à estruturada, clássica, abandono da estrutura regular e lógica, das ligações conjuntivas subordinadas e coordenadas. Uso do anacoluto;

- uso do modo imperfeito, que visa a dar ao leitor a impressão de que assiste ou testemunha os fatos descritos: linguagem imaginativa, de animação constante;

- uso da metáfora e do símile, da linguagem expressiva, colorida e sonora;

Na captação de um mundo de aparências efêmeras, o impressionista inventa paisagens que parecem mais autênticas que a realidade. A Estação de St. Lazare (FIGURA 10) de Claude Monet nos dá uma impressão real de uma cena da vida cotidiana da Europa oitocentista, em Paris. Neste quadro, que pertence à série de doze telas em que Monet pintou a Gare de Saint Lazare em vários momentos, está representado o valor atribuído ao progresso material da técnica pelo agigantamento da locomotiva a vapor, em primeiro 
plano, e pelas figuras humanas mal delineadas no seu entorno. A atmosfera nebulosa onde predomina a cor azul do céu que transparece pelo vidro da cobertura da estação dá o tom diurno e solar, refletindo tons amarelos e claros no ambiente, que demarcam bem as sombras contrastantes. As pinceladas coloridas (pontilhismo) que compõem o chão e demais elementos espaciais dão a impressão do movimento; e os edifícios laterais, em perspectiva, e estáticos, reforçam a idéia que Monet, nesse quadro (e nos outros que compõem a série de pinturas sobre Gare) capta, mais que o instante da partida e da chegada dos que pela via férrea viajam, em meio ao burburinho e ruídos típicos da estação de trens, a impressão da luz natural que se mistura ao vapor exalado pela locomotiva, numa composição harmônica entre natureza e técnica. É um espaço onde o limite do dentro e do fora não existe. Existe apenas a representação dele pela cor preta da estrutura de ferro e pela transparência dos vidros que delineiam a estação. Tudo remete à fugacidade do instante que passa e não volta mais. Tudo é efeito da luz.

Gombrich observa: "Monet não está interessado na estação ferroviária como um lugar onde seres humanos se encontram ou se despedem; está fascinado pelo efeito da luz, que escore através do telhado de vidro e se mistura às nuvens de vapor, e pela forma da locomotiva e carruagens que emergem da confusão"130. Não difere disso, pelo efeito movimento, de luz e nebulosidade, de ausência de contornos nítidos, na descrição que o sujeito poético faz da atmosfera da movimentada Lisboa ao anoitecer, nas estrofes iniciais da Parte I de OSO. A neblina a tudo mistura "edifícios, com as chaminés, e a turba" (I-2), fazendo-se perder a nitidez dos contornos; e o movimento cria a confusão: Os versos "Batem os carros de aluguer ao fundo, / Levando à via-férrea os que se vão. Felizes!” (I-3), são exemplos disso. A partir da fragmentação das imagens do cotidiano o sujeito poético, à semelhança do pintor impressionista, que com rápidas pinceladas busca no expressar dos

\footnotetext{
${ }^{130}$ GOMBRICH, op. cit., p.520.
} 
momentos do dia a dia a harmonia da existência, possibilitada pela arte: "um livro que exacerbe". Neste sentido, os versos de João Cabral de Melo Neto acerca da poesia cesariana são precisos: “Cesário Verde usava a tinta / de forma singular: / não para colorir, / apesar da cor que nele há. [...] Assim chegou aos tons opostos / das maçãs que contou; / rubras dentro da cesta / de quem no rosto as tem sem cor." , num jogo de palavras e cores que reverenciam o "poeta-pintor".

Em 1986, Helena de Carvalhão Buescu ${ }^{131}$, a propósito da visualidade e espacialidade na poesia de Cesário Verde, aponta três gestos fundamentais: “a pintura como atitude", "a pintura como metáfora", "a pintura como processo". A pintura como atitude é definida pela atividade de deambulação, que rompe com o imobilismo e a pose dos ateliês, de que Num Bairro Moderno e OSO são exemplos de percursos exteriores (espaço físico) e interiores (espaço da emoção): Deslumbramentos, Esplêndida e $A$ Débil, são exemplos de contemplação (apenas aparente), posto que, ao descrever com o olhar móvel, o sujeito tece os fragmentos do espaço, revelando a visão de mundo do autor, contrária às injustiças socioespaciais, como depreendemos do poema Cristalizações. Neste sentido, deambular significa uma nova atitude para com a poesia, descritiva do movimento, diferente da tradicional, de posição fixa, ou narrativa de percurso que remete à Divina Comédia de Dante.

Pinturas como metáfora são expressões que indicam a atividade de transformação, ou seja, a "poetização de um real à primeira vista aparecendo como prosaico", duas composições justapostas, uma percebida pelos sentidos, outra do sentimento decorrente, como já vimos no Capitulo I, na movimentação das varinas, calceteiros, camponeses, entre outros, ou pela "visão de artista", em Num Bairro Moderno, a qual sobrepõe "dois quadros" em uma mesma moldura, a da vendedeira e da criatura recomposta a partir das hortaliças e

\footnotetext{
${ }^{131}$ Apud: ANTONIO, Jorge Luiz, op. cit., p.312-315.
} 
legumes de que ela dispunha em sua "giga". Remete, também, ao interseccionismo, na medida em que a fusão das duas visões é assumida conscientemente, "enquanto modo de produção poética".

A pintura como processo aponta para o modo como a atividade pictórica e a transformação, vistas anteriormente, põem em evidência o sujeito poético, ao fragmentar-se em olhos e olhares, como também de si dirá Pessoa mais tarde de forma obsessiva. Quem vê?, quem sente?, quem transforma?, quem compõe? O sujeito esboça-se como onipotente, "mas uma plenitude institui sempre um vazio", lembra-nos a autora, ao concluir: "Desta poesia poderemos dizer que utiliza o mundo da sua referência como processo de circunscrição, não de um sujeito, mas de uma atitude (interrogação) de sujeito." A concepção estética da espacialidade nos três gestos (pintura como atitude, pintura como metáfora e pintura como processo) reflete, correspondentemente, a atitude do sujeito para com o mundo (da sua poesia e do "real" do qual emana), a atitude do sujeito para com seu universo poético e a atitude do sujeito consigo próprio nas relações arte-realidade. 


\section{CONCLUSÃO}

Mais no sentido de finalizar esse trabalho que no de concluir algo, retomamos a ideia inicial de que, no período em que viveu Cesário Verde (1855-1886), Portugal estava em profunda transformação, após o longo período da crise provocada pelas invasões napoleônicas, pelas lutas liberais, pela perda da colônia brasileira, pela ascensão da burguesia ao poder e pela instabilidade política e governativa. Sob a égide do partido regenerador, introduzido pelo levante militar de Saldanha (1851), que encaminhou sua atuação para melhoramentos materiais, difundindo confiança e progresso, há uma aparente estabilidade política. Entretanto a especulação desenfreada leva à queda do governo regenerador, pela Revolta da Janeirinha (1868), e conduz à crise econômica de 1876, quando surge o partido progressista, que irá alterar o poder com o regenerador até o fim da monarquia. Com o regresso de Fontes Pereira de Melo (1871-1877) ao poder, o Fontismo Regenerador traz grandes transformações na produção industrial, fomento agrícola, comercialização de produtos, aumento do consumo e das classes trabalhadoras assalariadas, multiplicação dos meios de transporte e comunicação, favorecendo a economia. Paralelamente, como sintoma da dificuldade da vida no campo, há enorme emigração para as cidades e para o Brasil. Lisboa conhece os problemas peculiares do rápido desenvolvimento a que o poder não sabe dar resposta, principalmente no que diz respeito ao caos urbano e à salubridade pública. Tuberculose, febre amarela e peste dizimam a capital. Assim, o desenvolvimento capitalista ali se revela caótico.

Sensível a essas transformações, poeta da cidade, sobretudo que era, Cesário Verde se deixa influenciar por elas em sua poesia, que ao mesmo tempo as descortina ao leitor. Poeta genuíno e original, conhecedor dos recursos estilísticos de rigor formal, ele trabalha com temas que exploram as causas do sofrimento humano, como a angústia e as injustiças 
socioespacias. Considerado renovador da lírica portuguesa pela exploração do cotidiano, Cesário Verde, ao descrever os tipos e quadros citadinos e rurais, revela atitudes subjetivas provocadas por essa vida exterior. Sua escrita lapidar, antirromântica, pela reserva irônica e rigor compositivo de seus versos, dá-nos a ver, através de sua imaginação transfiguradora, a cidade e o campo. Aquela, em seus vícios, misérias e sofrimentos; este, em sua vitalidade, saúde e liberdade. Em contraposição à pulsão da morte, existente na cidade, local de humilhação dos que nela buscam trabalho ou amor, Cesário identifica-se com a pulsão da vida característica do campo, local de trabalho, onde acontecem alegrias e tristezas. Por exemplo: "No campo; eu acho nele a musa que me anima": (De Verão, E.1), em oposição à: "Triste cidade! Eu temo que me avives uma paixão defunta!”(OSO, II-9), imagem do medo, da desolação e da morte.

A expressividade verbal, adjetivação abundante e rica, a precisão vocabular, o colorido da linguagem, frases curtas e acumulativas, justapostas, exclamações e reticências, quadras em versos decassílabos ou alexandrinos dos poemas deixam transparecer a problemática de sua obra: o desconcerto de mundo que, através da escrita, o poeta busca recompor. Assim, o processo de análise e interpretação das relações espaciotemporais em O Sentimento dum Ocidental permitiu-nos uma compreensão maior da poesia de Cesário Verde como um todo, pelo movimento sincrônico de recolha e disseminação dos elementos poéticos que a caracterizam. O poema, entendido como ponto de partida e de chegada da problemática cesariana e núcleo irradiador de uma visão de mundo, possibilitou, também, uma releitura de nossos dias a partir dela. Ante a fragmentação do sujeito e do mundo, o caminhar e o escrever criam novas relações de dimensão poética que envolvem também o leitor nesse processo.

Mais que a dicotomia campo-cidade, que contrapõe o espaço urbano ao espaço rural, comum em algumas obras realistas mencionadas ao longo da dissertação, é evidente 
que sua poesia expressa o sentimento de contrariedade às injustiças socioespaciais e à desumanização do homem pelo modo de uso da técnica, antecipando o que seria uma das preocupações de Ortega y Gasset: "Uno de los temas que en los próximos años se va a debatir com maior brio es el sentido, ventajas, daños y limites de la técnica" ${ }^{132}$, o que denota a sensibilidade extraordinária do poeta e sua preocupação autêntica com o indivíduo e com a nação, com o ser e com mundo.

Sem querer aqui, neste momento, aprofundar a questão geográfica a que Milton Santos denomina Período-Técnico-Científico-Informacional e Período Popular da História, seu estudo nos leva a compreender que vivemos hoje de modo intensificado a problemática do século XIX, ou seja, os desdobramentos da Revolução Industrial e Liberal. A fragmentação do cotidiano pelo uso do modo de produção (eletrônica), decorrente do meio técnico-informacional(fibra ótica), à semelhança do século XIX, gera a angústia existencial e consequências funestas das desigualdades socioespaciais, como a violência e a fome no mundo, que bem merecem reflexão aprofundada. A poesia de Cesário, na medida em que remete ao cotidiano, lembra, nesta situação, o homem pós-moderno, “em que as grandes narrativas, segundo Lyotard, os sistemas de valores vigentes entraram em colapso, porque todos decepcionaram quando aplicados, devida à ação do tempo, das circunstâncias e às limitações dos indivíduos"133. E, na concepção de Linda Hutcheon a propósito da arte pósmodernista, ela "pode ser capaz de dramatizar e até provocar a mudança a partir de dentro" ${ }^{\text {134 }}$. Entretanto, por ser outro o enfoque aqui, adiaremos a reflexão sobre tal assunto.

Nos versos de Cesário, a partir do diálogo que o leitor estabelece com o texto, há o espaço da enunciação, do subentendido, que se alia ao sujeito poético, tornando visível o que no poema é invisível: por exemplo, a angústia existencial e as desigualdades

\footnotetext{
${ }^{132}$ GASSET, Ortega y. Meditación de La Técnica. In: Obras Completas. $3^{\text {a }}$. Ed. Madri: Revista do Ocidente, 1955, Vol V, p 319. Um dos temas que nos próximos anos se vai debater com maior brio é o de sentido, vantagens, danos e limites da técnica. (Tradução nossa)

${ }_{133}$ Apud. RIBEIRO, Raquel de Sousa. Op. Cit., p. 339.

${ }^{134}$ Idem, ibidem. P. 340.
} 
socioespaciais; a angústia do sujeito proveniente do não-saber do futuro, dele, enquanto indivíduo, e da nação, enquanto coletivo. Embora já se apresente como promessa de progresso na Europa do século XIX, Portugal vive ainda a opacidade, a incerteza da sua concretização, como os versos "tal soturnidade, tal melancolia" e "o céu parece baixo e de neblina" bem expressam e, também, as desigualdades socioespaciais pela divisão internacional de trabalho que relegou à nação portuguesa no século XIX a mão-de-obra, nas poucas indústrias existentes, de capital estrangeiro. Tal fato não passa despercebido ao poeta que expressa seu descontentamento através da lírica: "De um couraçado inglês vogam escaleres"; e "Chora-me o coração que se enche e que se abisma." A predominância de naus estrangeiras no porto torna evidente a defasagem de Portugal em relação a outras metrópoles européias, bem como traduz a angústia do poeta ante tal realidade presente.

Se vista como um todo, a cidade sugere opressão e confinamento. Transcrevendo: “mas se vivemos, os emparedados,", o caminhar e a escritura são meios de sair, livrar-se da opressão e buscar novos horizontes. Se, nesse contexto, escrever é um modo de libertar-se interiormente: "E eu, que medito um livro que exacerbe, / Quisera que o real e a análise mo dessem" (III-5), viajar para metrópoles européias industrializadas, "São Petesburgo, Londres, Paris, o Mundo" (I-3), é modo de o sujeito lírico se libertar exteriormente.

Cesário Verde, poeta português do século XIX, em O Sentimento dum Ocidental, longo poema em quatro tempos (do anoitecer ao amanhecer) - uma alegoria da nação portuguesa que sofridamente ingressava na Era Industrial, publicado no Jornal de Viagens, Edição Especial: Portugal a Camões, Porto, (1880), trata de questões relativas ao uso da técnica, de suas consequências e do sentimento que tal uso pode desencadear, antecipando, assim, uma problemática, que não só afligia ocidentais de seu tempo, como alcançaria proporções mundiais com a chamada globalização do final de século XX e início do XXI. Ao enviar o poema, versado em quartetos de longos decassílabos e alexandrinos, para o 
jornal do Porto, acompanhou-o de uma carta, que dentre outras coisas, dizia o seguinte: “[...] mas julgo que fiz notar menos mal o estado presente desta grande Lisboa, que em

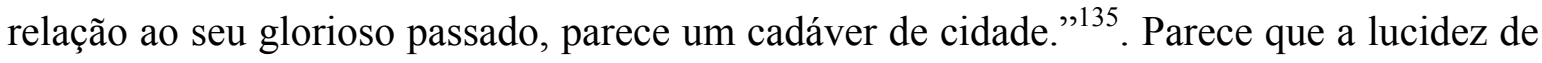
Cesário, longe de descartar a imagem anterior de nação, aumenta-lhe a significação pela dialética presente/passado; a bem entender, passado heróico, nos moldes clássicos, e presente heróico, nos moldes modernos de cotidiano, revelando sua permanente transformação.

Vivemos, hoje, segundo Milton Santos, o final do que ele define como Período Técnico-Cientifico-Informacional da História, que tem suas raízes fincadas na Revolução Industrial e seus desdobramentos, mas já vislumbramos no horizonte a emergência de um novo período: o Período Popular da História, onde e quando os aconteceres solidários do lugar determinam as novas relações socioespaciais. Verificamos que, apesar do traçado das ruas de Lisboa de hoje guardarem características da cidade medieval e da cidade pombalina, sua expansão, densidade populacional e transformação urbana se fazem notar, como confirma na foto aérea (FIGURA 11).

Daí podermos dizer, a um primeiro e modesto estudo da obra poética de Cesário Verde, do enriquecimento que traz à análise literária a aproximação entre espaço geográfico e espaço poético. Tendo em vista este "corpo-alma" que as relações espaciotemporais em $O$ Sentimento dum Ocidental sugerem (e que a obra como um todo reafirma), acentua-se a possibilidade de diálogo com o mundo do presente, pela fragmentação socioespacial, verdade emocional, natureza dos conflitos e sentido de busca incessante do sujeito/nação, que, a despeito de tudo, não desiste da esperança, conforme se lê nos versos finais do poema: “A Dor humana busca novos horizontes/e tem marés de fel como em sinistro mar." (OSO, estrofe final do poema).

\footnotetext{
${ }^{135}$ ANTONIO. Op. Cit. , p.267.
} 
Campo e cidade representam na obra poética um todo que passa a ser metáfora da existência, a exemplo do poema de Caeiro (ANEXO G), o que possibilita, a partir das relações espaciotemporais, estabelecer um diálogo com O Caminho do Campo, de Heidegger, cujo fragmento transcrevemos a seguir e que merece uma reflexão aprofundada, em outro momento:

Quando os enigmas se acotovelavam e nenhuma saída se anunciava, o caminho do campo oferecia boa ajuda: silenciosamente acompanha nossos passos pela sinuosa vereda, através da amplidão da terra agreste. O pensamento sempre de novo às voltas com os mesmos textos ou com seus próprios problemas retorna à vereda que o caminho estira através da campina. Sob os pés, ele permanece tão próximo daquele que pensa quanto do camponês que de madrugada caminha para a ceifa. ${ }^{136}$

Em contraposição à fragmentação e à pulsão de morte latente em seus versos, dos quais "marés de fel” é a síntese, há, com igual intensidade, a pulsão de vida pelo movimento de busca que a expressão "amplos horizontes" sintetiza. Tal nos permite depreender da obra a visão de mundo do autor: um mundo desconcertado que ele busca através da lírica concertar. Ante a fragmentação do sujeito e do mundo, no século XIX, pela perda de identidade do indivíduo e da nação, Portugal já não se reconhece mais como costumava no passado histórico renascentista das grandes navegações. Nesse sentido, Rafael Bordalo Pinheiro (1846-1905), desenhador, caricaturista, jornalista, professor e ceramista, já havia criado em 1875 a personagem “Zé-Povinho” (FIG. 12), representando o homem do povo, esperto e atento, que se tornou símbolo nacional. A aceleração da vida pelo meio técnico nas cidades grandes européias que passavam por transformações de toda sorte, entre outros fatores, traz ao homem ocidental o sentimento de angústia e solidão.

\footnotetext{
${ }^{136}$ HEIDEGGER, Martin. O caminho do campo. Trad. Ernildo Stein. SP: Duas cidades, 1969, p.67.
} 
Cesário Verde, através de sua lírica, descreve as relações espaciotemporais de Lisboa (campo-cidade) oitocentista nesse contexto e propõe a esperança como saída. Nessa busca do sujeito poético, o percurso e o cotidiano, o caminhar e o escrever, o físico e a emoção vão sendo chamados a compor uma nova realidade que se consagra na obra poética. Relacionar, portanto, os elementos conteudístico-formais de sua poesia com contexto histórico-geográfico em que viveu, dá-nos a leitura da problemática da obra e visão de mundo do autor. A atualização disso em nossos dias pode propiciar reflexões acerca do espaço-tempo em que vivemos e instigar novas atitudes conciliadoras do homem com o mundo. Após anos de estudo dedicados à análise das relações espaciotemporais na literatura, foi na obra de Cesário Verde que tivemos mais claramente vistas ao processo de busca de totalização (harmônica) ante a fragmentação do sujeito, do mundo e da existência, através do fazer poético. Na sua "lírica deambulatória", na expressão de David MourãoFerreira, ou "poesia de transeunte", na observação de Jacinto do Prado Coelho, como ressalta Carlos Felipe Moisés, é imediato surpreender nesse aspecto, não só o “correspondente literário da pintura ao vivo dos impressionistas, mas o prenúncio da tendência à dispersão e à despersonalização, característica de boa parte da poesia moderna." Concluindo, mais adiante, “[...] avaliado sem preconceitos (ou à luz da também preconceituosa modernidade?), Cesário se revela, mais de cem anos depois, indiscutivelmente nosso contemporâneo." 137

Dentro dos limites a que se propôs este trabalho, buscamos, também, reforçar a ideia de que, se a seu tempo a obra não teve o reconhecimento que o poeta esperava, com o passar dos anos os admiradores e estudiosos, leitores e pesquisadores a colocaram em posição de destaque, na lírica de língua portuguesa, e Cesário, precursor primeiro dos rumos que a literatura ocidental iria tomar no início do século $\mathrm{XX}$ em diante. O próprio

\footnotetext{
${ }^{137}$ MOISÉS, Carlos Felipe. 2001. Op. Cit., p. 217.
} 
título do conto de Miguéis Saudades para Dona Genciana (1968), mencionado na Fortuna Crítica, evoca o verso de Cesário "Eu trouxe do jardim duas saudades roxas" (Melodias Vulgares, E.21) e aproxima ambos os textos pela imagem de morte que esta flor sugere.

A partir da análise das relações espaciotemporais no poema $O$ Sentimento dum Ocidental, foi constatado um permanente processo de fragmentação e busca de totalidade presente na obra poética de Cesário Verde como um todo. Este processo foi verificado em três aspectos indissociáveis e interagentes, a saber: em relação ao sujeito, em relação ao espaço e em relação à linguagem, que na dissertação aparecem separados por razões de ordem analítica.

Em relação ao sujeito, depreendemos que a totalidade do "eu" é representada pelo diálogo entre sujeito observador, que capta a realidade exterior através dos sentidos (visão, olfato, tato, audição, paladar), e sujeito lírico, que transmuta em sentimento (angústia e desejo de esperança, por exemplo) aquilo que foi observado. Ambos, sujeito observador e sujeito lírico, compreendem o sujeito poético que configura a totalidade do que é representado pelo diálogo, o qual expressa o sentimento de busca de harmonização pela poesia. O efeito poético resultante da construção proveniente da fragmentação e busca de totalidade denuncia a visão de mundo marcada pela instabilidade e movimento. Ante o desconcerto de mundo e o sentimento de angústia dele decorrente, o poeta busca uma nova realidade que expressa no poema. Ao compor, o sujeito poético busca perfazer a totalidade a partir da fragmentação sujeito observador (sentidos) e sujeito lírico (sentimento), evidenciando no diálogo entre eles a busca da harmonia na poesia. Neste processo, a relação entre olho, perspectiva de onde o sujeito vê, e olhar, formas de percepção do simbólico e da cultura, deixa transparecer a visão de mundo do autor que, ao denunciar a fragmentação, (des)ordem do mundo em que vive e que o inspira, busca recriar nova ordem, ou seja, nova totalidade. 
Em relação ao espaço, dialogam na obra poética de Cesário o espaço físico (objetivo, Lisboa oitocentista) e o espaço da emoção (subjetivo, lírico sentimental). No dia a dia e no caminhar do sujeito afloram as injustiças socioespacias na relação campo-cidademundo, a visão em foco e em perspectiva, que traduzem a fragmentação do espaço em paisagens e lugares, como, por exemplo, paisagem urbana e paisagem rural, lugar de trabalho e lugar de lazer, que as antinomias dialéticas e outros recursos expressivos, entre os quais, substantivos, verbos, adjetivos, locuções adverbiais, que buscam recriar como totalidade do "território vivido", ou seja, do território usado, espaço banal, espaço de todos. O cotidiano e o percurso do sujeito na Lisboa oitocentista, bem como sua memória e história, e o sentimento daí decorrente, possibilitam ao leitor visualizar a época do poeta e aproximá-la do mundo em que vive, refletindo sobre suas semelhanças e diferenças.

Em relação à linguagem, que no sentido de totalidade do poema se apresenta fragmentada em episódios e cenas, como, por exemplo, o episódio da vendedeira de frutas e legumes em Num Bairro Moderno e a cena dos calceteiros na rua macadamizada de Cristalizações, o autor lança mão de recursos poéticos, sendo que alguns remetem às características da pintura impressionista, sugeridos pelos adjetivos, verbos e outros que configuram o campo semântico, para expressar verbalmente o instantâneo, a luz, o movimento que busca traduzir através da poesia.

Em resumo, a relação do sujeito com a linguagem escrita, o processo de fragmentação e busca de totalidade se configuram no fazer poético. Do ponto de vista do espaço, ele ocorre no cotidiano e através do percurso. E do ponto de vista da linguagem, tal processo se dá, através de imagens verbais, na própria composição poética como um todo.

A partir dos três aspectos abordados nesta dissertação, queremos demonstrar que é evidente o processo de fragmentação ou (des)ordem e a busca de nova ordem, totalidade, que, entretanto, nunca chega a realizar-se. O sujeito busca a esperança na relação consigo, 
com o outro e com o mundo, ou seja, busca "novos horizontes", através do processo de harmonização pela arte de "compor com versos magistrais". Isso remete à verossimilhança, na concepção aristotélica, que distingue verdadeiro de verossímil. Lembrando as palavras de Ricardo Marques de Azevedo:

Remontando à distinção aristotélica entre verdadeiro e verossímil, estima-se que, pelas operações da Arte que o Espírito esteja aparelhado para conceber excelências que a natureza por si só seria incapaz de produzir. E isso se credita não apenas às operações seletivas, corretivas e reunitivas: o gênio imaginativo, diz-se, é dotado de certo poder entusiástico pelo qual prodigaliza uma força peculiar e uma expansão expressiva que arrebatam. ${ }^{138}$

Entendendo-se, aqui, verdadeiro como espaço físico e verossimilhante como espaço poético, remete, também, por isso, à concepção platônica, da qual se aproxima no sentido de plenitude. Neste movimento de aproximação e distanciamento do mundo ideal, o ser humano, representado pelo sujeito poético, constrói-se e se desconstrói através da poesia, a qual, por sua vez, suscita no leitor o mesmo processo de fragmentação e busca de totalidade em relação a ela e à vida, ao mundo em ele que vive, estabelecendo, de certo modo, um diálogo contínuo entre o verdadeiro e o verossimilhante, entre o eu e o outro.

Considerando totalidade como organicidade e interação das partes com todo e entre si, numa harmonia dos fragmentos entre si e em relação ao todo, podemos dizer que a busca de totalidade no poema $O$ Sentimento dum Ocidental e na obra poética de Cesário, ante a fragmentação do sujeito, do espaço, do tempo e da linguagem, é representada, sobretudo, pelo seguinte:

\footnotetext{
${ }^{138}$ AZEVEDO, Ricardo Marques de. Antigos e Modernos: Contribuição ao estudo das doutrinas Arquitetônicas (Séculos XVII e XVIII), p.18. Tese de Livre-Docência. Departamento de História da Arquitetura e Estética do Projeto. FAU-USP, 2007.
} 
- aspiração à evasão do emparedamento individual e nacional,para viver livremente;

- resgatar a memória da nação em sua grandeza perdida pelas injustiças, crueldades, prisões, perseguições, que "enlutam" e possibilidade de vislumbrar "novos horizontes";

- esperança de superação à dor física, moral e existencial, para bem se relacionar consigo, com o outro e com o mundo, guardado o respeito entre classes reais e imaginárias, entre empregados, empregados que se fazem de patrões e patrões;

- vontade de harmonização socioespacial, seja ela na cidade ou no campo, visando à busca de equilíbrio entre civilização e natureza, pela consciência da diferença entre valor de troca e valor de uso, confundidos na sociedade industrial capitalista, cuja economia visa ao lucro monetário em detrimento de bens naturais;

- desejo de alcançar a realização amorosa e não desencontro dos pares, representado pelo cômico ou pelo rebaixamento que desmontam a construção idealizada do amor;

- anseio, em termos artísticos, de "compor versos magistrais" presos ao real, entendidos no plano da linguagem como rima, ritmo, métrica e outros recursos estilísticos, que encontram na leitura sua complementação, ainda que provisória, pois, lembrando Schopenhauer, também para o leitor o prazer da leitura é momentâneo e logo se desfaz;

Em suma, a análise da obra poética de Cesário Verde, tendo por ponto de partida e de chegada o poema $O$ Sentimento dum Ocidental, quer indicar que o poeta foi bemsucedido em seu intento de provocar nova busca, novo enigma, como mistério e desafio para cada leitor, que por mimese presentifica a emoção que o autor sentiu ao escrever seus versos. Entendida como superação de tudo e complemento do que falta ao ser humano, a totalidade é também a parte do outro que o completa. Assim compreendidas, fragmentação e busca de totalidade, ao se alterarem em sua poesia, num processo que nunca encontra a plenitude absoluta e logo cede à nova fragmentação, remetem ao processo contínuo de construção e desconstrução que constitui a essência da própria vida. 


\section{BIBLIOGRAFIA}

\section{Do Autor}

VERDE, Cesário. Obra Completa de Cesário Verde. (Org. SERRÃO, Joel). $8^{\mathrm{a}}$ ed. Lisboa: Livros Horizonte, 2003.

VERDE, Cesário. Interpretação, Poesias Dispersas e Cartas. (p/Joel Serrão). Lisboa: Delfos, 1961.

VERDE, Cesário. Boletim Cultural. VI série - no7- Julho de 1986. Lisboa: Fundação Calouste Gulbenkian. (Serviço de Bibliotecas Itinerantes e Fixas).

VERDE, Cesário. Poesia Completa \& Cartas Escolhidas / Cesário Verde. Organização, Prefácio e Notas de Carlos Felipe Moisés. São Paulo: Editora Cultrix, Editora da Universidade de São Paulo, 1982.

VERDE, Cesário. Obra Poética Integral de Cesário Verde. (Org., apresentação, tábua cronol., e cartas escolhidas por Ricardo Daunt). São Paulo: Landy Editora, 2006.

VERDE. Cesário. O Livro de Cesário Verde: texto integral e estudo da obra. (Introdução: António Capão). Porto: Paisagem Editora Ltda., 1982.

VERDE, Cesário. O livro de Cesário Verde. Poemas. (Edição e notas de Sérgio Faraco) Porto Alegre: L\&PM editores, 2008.

VERDE, Cesário, Melhores Poemas. (Seleção e Prefácio de Leyla Perrone-Moisés). São Paulo: Global Editora, 2005.

VERDE, Cesário. Cânticos do Realismo e Outros Poemas-32 Cartas. (Edição Teresa Sobral Cunha). Lisboa: Relógio D’Água Editores. 2006.

VERDE, Cesário. Poesias Completas de Cesário Verde. Coleção Prestígio. (Org., introdução e notas de Osmar Barbosa). Ediouro, 1987.

PASCHOALIN, Maria Aparecida. Cesário Verde. (Seleção de textos, notas, estudos biográfico, histórico e crítico e exercícios). São Paulo: Abril Educação, 1982.

\section{Sobre o Autor e a Obra:}

AMARAL, Henrique do. A captação do real em Cesário e em Baudelaire. In: Vértice. Vol. XV, no 147, Coimbra, Dezembro de 1955, pp. 727-732.

AMBRÓSIO, António. Cesário Verde perante a Igreja. In: Diário de Notícias, Lisboa, 21 de dezembro de 1986. 
ANTONIO, Jorge L. Cores, Forma, Luz, Movimento: A Poesia de Cesário Verde. São Paulo: Musa Editora. FAPESP, 2002.

BOM, Laurinda; Laura Areias. Cesário Verde. Uma Proposta de Trabalho. [Ed. escolar]. Lisboa: Livros Horizonte, 1983.

COELHO, Jacinto do Prado - Um Clássico da Modernidade: Cesário Verde. In: Problemática da História Literária. Lisboa: Ática, 1961, pp. 219-224.

Cesário e Baudelaire. Ibid., pp. 225-232. Cesário Verde Escritor. Ibid., pp. 233-239.

CUNHA. Carlos. Cesário, poeta moderno. Braga: Livraria Cruz, 1957.

DAUNT, Ricardo. O Livro de Cesário Verde: Leituras e Comparações. (Tese de Doutoramento) USP, 1999.

ESRADA LARGA. Porto. Porto Editora, Vol.I, s/d No Livro de Cesário Verde, por Silva Pinto, p. 379; Para uma biografia de Cesário, por Luís Amaro de Oliveira, pp. 381385; Introdução ao estudo de Cesário, por Antônio Salgado Júnior, pp. 386-391; Sobre o realismo de Cesário, por José Régio, pp. 392-395; A presença do real na Poesia de Cesário Verde, por Andrée Crabeé Rocha, pp. 396-398; Cesário e Baudelaire, por Jacinto do Prado Coelho, pp. 399-402; Sobre o Sentido da Morte na Poesia de Cesário Verde, por Joel Serrão, pp. 403-407. A linguagem de Cesário Verde, por Jorge de Sena, pp. 409-413; Tolentino e Cesário, por Oscar Lopes, pp. 414-417.

FERREIRA, Joaquim. História da Literatura Portuguesa. $4^{\mathrm{a}}$ ed. Porto: Editorial Domingos Barreira, 1971.

FERREIRA. Vergílio. Relendo Cesário. In: Colóquio/Letras, no. 31, Lisboa, Maio de 1976, pp. 49-58.

FIGUEIREDO, João Pinto. A Vida de Cesário Verde. Lisboa: Editorial Presença, 1896.

LOPES, Oscar. Cesário ou do Romantismo ao Modernismo. In: Vétice, vol. XXVII, no. 284, Coimbra, maio de 1967, pp. 257-265.

LOPES, Rita Sousa. Para uma leitura de Cesário Verde. Lisboa: Edtl. Presença, 2000.

MACEDO, Helder. Nós: uma leitura de Cesário Verde. Lisboa: Editorial Presença, 1999.

MARTINS, Cabral. Cesário Verde ou a Transformação do Mundo. (Coleção Estudos da Cultura Portuguesa). Lisboa: Editorial Comunicação, 1988.

MATHIAS, Marcello Duarte. Autobiografias e Diários. In: Colóquios/Letras, JaneiroJunho 1997, número 143/144.

MOISÉS, Carlos Felipe. Modernismo. In: O Desconcerto do Mundo: Do Renascimento Ao Surrealismo. SP: Escrituras Editora, 2001 - (Coleção Ensaios Transversais). 
MOISÉS, Massaud. A Criação Literária. Poesia. São Paulo: Cultrix, 1986.

A Literatura Portuguesa. 35ª . Edição. São Paulo: Cultrix, 2008.

Dicionário de Termos Literários. São Paulo: Cultrix, 2002.

Romantismo e Realismo, vol.III. Presença da Literatura Portuguesa.

São Paulo: Difusão Européia do Livro, 1974

OLIVEIRA, Luís Amaro de. Cesário Verde (Novos subsídios para o estudo da sua personalidade), Coimbra: Editora Nobel, 1944.

PASCHOALIN, Maria Aparecida. A poesia de Cesário Verde: Lirismo e Realidade Social. (Dissertação de Mestrado pela USP), 1980.

PERDIGÃO, Maria Madalena de Azeredo et alii. Cesário Verde: comemorações do centenário da morte do poeta. Lisboa: Fundação Calouste Gulbenkian, 1993.

PEREIRA, José Carlos Seabra - Decadentismo e Simbolismo na Poesia Portuguesa. Coimbra, 1975

RECHERT, Stephen. Um ramalhete para Cesário. Lisboa: Editorial Minerva, 1987.

REIS, Carlos. História da Literatura Portuguesa. Vol. 5. Publicações Alfa.

RÉGIO, José. Sobre o Realismo de Cesário. In: Estrada Larga, vol. I, Porto, Porto Editora, 1958, pp. 392-395.

ROCHA. Andrée Crabeé. A Presença de Real na Poesia de Cesário Verde. In: Estrada Larga. vol.I , Porto, Porto Editora, 1958, pp.396-398.

Cesário Verde, poeta barroco? In: Colóquio/Letras, no1. Lisboa, 1971, pp. 31-33.

ROCHA, Clara. Máscaras de Narcísio: estudos sobre a literatura autobiográfica em Portugal. Coimbra: Almedina, 1992.

ROUGEMONT, Denis. História de Amor no Ocidente. Trad. Paulo Brandi; Ethel Brandi Cachapuz. 2a . ed. São Paulo: Ediouro, 2003.

SACRAMENTO, Mário. Lírica e Dialética em Cesário Verde. Ensaios de Domingo, Coimbra, 1959, pp. 93-137.

SENA, Jorge. A linguagem de Cesário Verde. Estrada Larga I. Porto, Porto Editora, Vol. I, 1958, pp. 409-413.

SERRÃO, Joel. Temas Oitocentistas - I e II Lisboa: Livros Horizonte, 1978.

SIMÕES. João Gaspar. Eça de Queirós, mestre de Cesário Verde e precursor da poesia moderna. In: O Primeiro de Janeiro, Porto, 14-3-1945. 
TORRES, Alexandre Pinheiro. A paleta de Cesário Verde. Lisboa, 2003.

VÉRTICE 15 (147) dez. 1955. : Cesário Verde. Para uma Edição Crítica das suas Poesias, por Joel Serão, pp. 683-717; Subsídios para um estudo sobre Cesário Verde, por Luís Eugênio Ferreira, pp. 718-724; A Captação do real em Cesário e em Baudelaire, por Henrique do Amaral, pp. 727-732; O povo na obra de Cesário Verde, por Luísa da Costa, pp. 733-735.

\section{Outras Obras}

ADORNO, Theodor. Lírica e Sociedade. Benjamin, Adorno, Horkheimer, Habermans. Temas escolhidos. Os Pensadores. Trad. Bras. São Paulo: Abril, 1980.

ALI, M. Said. Versificação portuguesa. São Paulo: Edusp, 1999.

AUERBACH, Erich. Figura. Trad. Duda Machado. São Paulo: Ática, 1997.

AZEVEDO, Ricardo Marques. Metrópole: Abstração. São Paulo: Editora Perspectiva, 2006. (Estudos; 224)

BACHELARD, Gaston. La Poétique de l'Espace. Paris: Quadrige / PUF.1992.

BACHELARD, Gaston. La Poética d'el Espacio. México: Breviários del Fondo de Cultura Económica, 1965.

BACHELARD, Gaston. O ar e os sonhos. Ensaio sobre a imaginação do movimento. São Paulo: Martins Fontes, 1997.

BAKHTIN, Mikhail. Questões de literatura e de estética. Trad.: Aurora F. Bernardini, José Pereira Jr., Augusto Góes Jr., Helena S. Nazário, Homero F. de Andrade. São Paulo: Hucitec/UNESP, 1988.

BARTHES, Roland. Como viver junto”. São Paulo: Martins Fontes, 2005. " "Fragmentos de um discurso amoroso". S P: Cia das Letras, 1995.

BAUDRILLARD, Jean. O sistema dos objetos. Trad.: Zulmira R. Tavares. São Paulo: Perspectiva, 1973.

BENJAMIN, Walter et alli. Sobre Alguns Temas em Baudelaire. Textos Escolhidas. $2^{\mathrm{a}} \mathrm{ed}$. São Paulo: Abril Cultural, 1983 (Os Pensadores).

Charles Baudelaire, um lírico no auge do capitalismo. Trad.: José Carlos M. Barbosa e Hemerson A.s Baptista. S P: Cia das Letras, 2000.

Obras escolhidas III - Charles Baudelaire. S P: Brasiliense, 1989.

BERGEZ, Daniel, et.alli. Métodos Críticos para Análise Literária. S P: M.Fontes, 2006. 
BOSI, Alfredo. Reflexões sobre a Arte. $3^{\mathrm{a}}$ ed. São Paulo: Editora Ática, 1986.

O Ser e o tempo da Poesia. São Paulo: Companhia das Letras, 1996.

BRIK, Óssip. Ritmo e sintaxe. Teoria da literatura - formalistas russos. Trad. Bras. Ana Mariza R. Filipouski e outros. Porto Alegre: Globo, 1976.

BUENO, Aparecida de Fátima ...[et alt.]. Literatura portuguesa: história, memória e Perspectivas. São Paulo: Alameda Casa Editorial. 2007.

CÂNDIDO, Antônio. Noções de análise histórico-literária. SP: Associação Editorial Humanitas. 2005.

Humanitas, 2006.

.0 estudo analítico do poema. $5^{\text {a }}$ ed. São Paulo: Associação editorial Recortes. São Paulo: Companhia das Letras, 1993.

Entre Campo e Cidade. In: Tese e Antítese. São Paulo. Companhia Editora Nacional, 1964.

Cidades, 1993.

CÂNDIDO, Antônio e CASTELLO, J. A Presença da Literatura Brasileira.

Modernismo. Rio de Janeiro: Bertrand, 1992.

CERTEAU, Michel de. A invenção do cotidiano. Rio de Janeiro: Vozes, 2001.

CIRLOT, Juan Eduardo. Dicionário de símbolos. Trad.; Rubens E. F. Frias. São Paulo: Moraes, 1984.

CHOCIAY, Rogério. Teoria do Verso. São Paulo: Mcgraw-Hill do Brasil Ltda, 1979.

COELHO, Jacinto do Prado. A letra e o leitor. Lisboa: Moraes Editores, 1977.

COELHO, Nelly Novaes. Literatura e Linguagem: a obra literária e a expressão linguística. Rio de Janeiro: Livraria José Olympio Editora, 1974.

COUTINHO, Afrânio. Introdução à Literatura no Brasil. $5^{\mathrm{a}}$. ed. Rio de janeiro: Editora Distribuidora de Livros escolares Ltda.

DISCINI, Norma. O Estilo nos textos. São Paulo: Contexto, 2003.

DUFRENNE, Mikel. O Poético.Trad. Luiz Arthur Nunes e Reasylvia Kroeff de Souza. Porto Alegre: Globo Editora, 1969. Titulo Original: Le Poétique.

DUBOIS, Jacques et alii. Retórica da Poesia. Trad. Carlos Felipe Moisés. São Paulo: Cultrix/Edusp, 1980. 
DURAN, Gilbert. O imaginário. Ensaio acerca das ciências e da filosofia da imagem. Trad. René Eve Levié. Rio de Janeiro: DIFEL, 1998.

EAGLETON, Terry. Literary Theory. An Introduction. 2a . ed. Mineapolis: The University of Minnesota Press, 1996.

ECO, Umberto. A estrutura ausente. Introdução à pesquisa semiológica. Trad. Pérola de Carvalho. São Paulo, Perspectiva, Editora da USP, 1971 (Coleção Estudos). Título original: La strutura ausente. Introduzione a la pesquisa semiológica.

-----, Umberto. História da Feiúra. Trad. Eliana Aguiar. Rio de Janeiro: Editora Record, 2007. Título original: Storia della brutezza.

-----, Umberto. Interpretação e Superinterpretação. 3ª ed. S P: Editora M. Fontes, 2001.

ELIADE, Mircea. Mito e Realidade. São Paulo: Editora Perspectiva, 2006.

ESTEBAN, Claude. Crítica da razão poética. Trad. Maria E.G.G. Pereira. São Paulo: Martins Fontes, 1991.

FERNANDES, Annie Gisele. Espaços do ser e do não-ser e a construção do sujeito em Mário de Sá-Carneiro. In: FERNANDES, Annie Gisele; OLIVEIRA, Paulo Motta. Literatura Portuguesa: Aquém-Mar. Campinas: Editora Komedi, 2005.

FERRARA, Lucrecia D’Alessio. Lugar na Cidade: Conhecimento e Diálogo. In: Território Brasileiro: Usos e Abusos. (Organização Maria Adélia Aparecida de Souza). Campinas: Edições Territorial, 2003.

FIORIN, José Luiz. Elementos de análise do discurso. S. Paulo: Editora Contexto, 2002.

FOUCAULT, Michel. O que é o autor? Trad. António Fernando Cascais e Eduardo Cordeiro. 6a . ed. Lisboa: Nova Veja, 2006. Título original: Qu'est-ce qu'un auteur?

A Ordem do Discurso. Aula inaugural no Collége de France, pronunciada em 2 de dezembro de 1970. Trad. Laura F. de A. Sampaio. São Paulo: Edições Loyola, 2007. Titulo Original: L'orde du discours. Leçon inaugurale au Collége de France, prononcée le 2 decembre, 1970.

FRANCASTELL, Pierre. O Impressionismo. São Paulo: Martins Fontes Editora, 1988.

FRIEDRICH, Hugo. Estrutura da Lírica Moderna: da metade do século XIX a meados do século XX. Trad.: Marise M. Curioni. S. Paulo: Duas Cidades, 1978.

GALVÃO, Jesus Bello. Subconsciência e afetividade na língua portuguesa. Rio de Janeiro: Livro Técnico/MEC, 1979.

GASSET, José Ortega Y. Obras Completas. 3ª Ed. Madri: Revista do Ocidente, 1955.

GOMBRICH. Ernest, H. A História da Arte. (Trad.: Álvaro Cabral). Rio de Janeiro: LTC- Livros Técnicos e Científicos Editora S. A. 16 ${ }^{\text {a }}$ Edição. 
GRATELOUP, Leon-Louis. Dicionário Filosófico de Citações. Trad.Marina Appenzeller. S P: Editora Fontes, 2004. Título original: Dictionnaire Philosophique de Citations.

HAUSER. Arnold. História Social da Arte e da Literatura. (Tradução de Álvaro Cabral). São Paulo: Livraria Martins Fontes Editora Ltda., 2003 (Paidéia)

HEGEL, Georg Wilhelm Friedrich. Cursos de Estética. I. 2a ${ }^{\mathrm{a}}$ ed. Trad. Marco Aurélio Werle. S Paulo: Edusp. 2001. Título original: Vorlesungen über die Ästhetik.

HEIDDGER, Martin. Eı Ser y el Tiempo. 4a ed. Trad. José Gaos. México: Editora Fondo de Cultura Econômica, 1971. Título original: Sein und Zeit.

HELLER, Agnes. O cotidiano e a história. Trad.: Carlos Nelson Coutinho e Leandro Konder. Rio de Janeiro: Paz e Terra, 1989.

HERMANN, Fabio. Psicanálise do Cotidiano. Porto Alegre: Artes Médicas, 1997.

JUDICE, Nuno. O processo poético. Estudos de teoria e crítica literárias. Lisboa: Imprensa Nacional/Casa da Moeda, 1992.

JUNG, Carl Gustav. O eu e o inconsciente $18^{\mathrm{a}}$ ed. trad. Dora Ferreira da Silva. Petrópolis: Editora Vozes, 2004. Título original: Zwei Schriften Über Analytische Psychologie. Die Beziehungen Zwischen den Ich und dem Unbewussten.

LACAN, Jacques. O Seminário, Livro 11: Os quatro conceitos fundamentais da Psicanálise (1964). Trad. M.G. Magno. 2ª ed.. Rio de Janeiro: Jorge Zahar, 1998

LAPA, M. Rodrigues. Estilística da Língua Portuguesa. 6a. Ed. Rio de Janeiro: Livraria Acadêmica, 1970.

LEFEBVE. Maurice-Jean. Estrutura do discurso da poesia e da narrativa. Coimbra: Livraria Almedina, 1980.

LEXICON, Herder. Dicionário de Símbolos. São Paulo: Cultrix, 199.

LINS, Osman. Lima Barreto e o espaço romanesco. São Paulo: Ática, 1976.

LOPONDO, Lílian. Org. Dialogia na Literatura Portuguesa. São Paulo: Scortecci Editora, 2006.

LOTMAN, Iuri. A estrutura do texto artístico. Trad.: Maria do Carmo V. Raposos e Alberto Raposos. Lisboa: Editorial Estampa, 1978.

LYOTARD, Jean-François. O Pós-Modernismo. Trad. Brás.. 3a. Ed. Rj: J. Olympio, 1990.

MAFESOLI, Michel. Elogio da razão sensível.Trad. Albert C.M. Stukenbruk. Petrópolis: Editora Vozes, 1998.

MATORÉ, Georges. L’espace humain. Paris: Nizet, 1996. 
MATTOSO, José. História de Portugal 1. V vol. O Liberalismo (1807-1890). Coord. LuísReis Torgal e João L. Roque.). Lisboa: Editorial Estampa, 1975.

MELETÍNSKI, Eleazar.M. Os Arquétipos literários. Trad. Aurora F. Bernardini e outros. São Paulo: Ateliê Editorial, 2002.

MERCHIOR, JoséG. Razão do poema: ensaios de crítica e estética. RJ: Topbooks, 1996. MOLES, Abrahão. A Criação Científica.

MONTEIRO, Carlos A. de F. O mapa e a trama. Florianópolis, SC: Ed. da UFSC, 2002. Territorial, 2008.

NALINI. José Renato. Justiça. Coleção Valores. SP: Edição Nova Canção, 2008.

PAZ, Octavio. O Arco e a Lira. Tradução de Olga Savary. 2a . ed. Rio de Janeiro: Editora Nova Fronteira, 1982. Título original: El Arco y La Lira.

O Desconhecido de si mesmo - Fernando Pessoa. Trad. Sebastião Uchoa Leite. In: "Signos e Rotações". 3ª ed. São Paulo: Editora Perspectiva, 2003.

PEREC, Georges. Espèces d'espaces. Paris: Gallimard, 1988.

PERRONE-MOISÉS, Leyla. Inútil Poesia. São Paulo: Companhia das Letras, 2000.

PINO, Claudia Amigo. A Fiç̧ão da Escrita, São Paulo: Ateliê Editorial, 2004.

POULET, Georges. O espaço proustiano. Trad. Ana L. B. M. Costa. SP: Imago, 1992.

RIBEIRO, Ana Clara Torres. Pequena reflexão sobre categorias da teoria crítica do espaço: território usado, território praticado. In: Território Brasileiro: usos e abusos. Org. Souza, Maria Adélia. Campinas, Edições Territorial, 2003.

RIBEIRO, Raquel de Sousa. A justaposição n'As naus, de Lobo Antunes: o silenciado em busca da forma. In: Literatura Portuguesa: história, memória e perspectivas. Aparecida de Fátima Bueno ... [et alli]. São Paulo: Alameda, 2007.

ROCHEFORT. Michel. O desafio urbano nos países do Sul. Campinas: Edições. Territorial, 2008.

SALGUEIRO. Teresa B. A Cidade em Portugal: uma geografia urbana. Porto: Edições Afrontamento, 1992.

SANTOS, Milton. A Natureza do Espaço: técnica e tempo, razão e emoção. São Paulo: Hucitec, 1999. 
Pensando o Espaço do Homem. São Paulo: Editora Huicitec, 2007.

De la Totalid al Lugar. Barcelona: Oikos-Tau, 1996.

SARTRE, Jean-Paul. Esboço para uma teoria das emoções. Trad.: Paulo Neves. Porto Alegre: LPM, 2007.

Que é a Literatura? Trad. Carlos Felipe Moisés. $3^{\mathrm{a}}$. ed. São Paulo: Ed. Ática, 2004. Título orig.: Qu'est-ce que la Littérature? Paris: Gallimard, 1948.

Critique de la Raison Dialectique. Tome I. Paris: Gallimard, 1960.

Questão de Método. Trad. Bento Prado Jr. São Paulo: Difusão Européia do Livro, 1966.

SOUZA. Maria Adélia A.(Org.).Território Brasileiro: usos e abusos. Org. Maria Adélia Campinas: Edições Territorial 2003.

Hucitec, 1996.

(Org.)O mundo do cidadão: um cidadão do mundo. São Paulo:

-(Org.) A Metrópole e o futuro. Campinas: Ed. Territorial, 2008.

STEIGER, Emil. Conceitos fundamentais da poética. Trad. Brasileira. Rio de Janeiro:

Tempo Brasileiro, 1972.

SUMERLIAN, Leon. Techiniques of Fiction Writing: Measure and Madness.

TOMACHEVSKI. B. Sobre o verso. Teoria da Literatura - Formalistas Russos. Trad. Bras. Ana Mariza R. Filipouski e outros. Porto Alegre: Globo, 1976.

WELLEK, René; A. Warren. Teoria da literatura e metodologia dos estudos literários. Trad.: Luís C. Borges. São Paulo: Livraria Martins Fontes Editora Ltda., 2003.

WILLIAMS, Raymond. O Campo e a Cidade: na história e na literatura. Trad.: Paulo Henriques Brito. São Paulo: Companhia das Letras, 1989. 


\section{SITES CONSULTADOS}

htpp://webcarta.net.cart/mapas

htpp:/www.e-cultura.pt/images

htpp://www.webserver.com.lisboa.pt

htpp://www.igeo.pt/images

hptt:/www.skyserapercity.com

htpp:/www.museedorsay.paris

htpp:/www.vanillanist.com

htpp://iep.uminho.pt

http://musee-orsay.fr

http://blx.cm-lisboa.pt

http://www.nomo.fc.ul.pt

http://www.prof2000.pt

http://www.vidaslusofonas.pt

htpp://webserver.cm-lisboa.pt

http://museubordalopinheiro.pt 


\section{ÍNDICE GERAL}

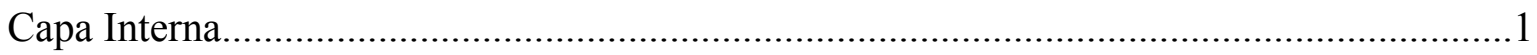

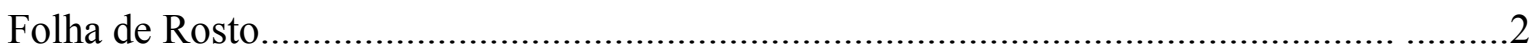

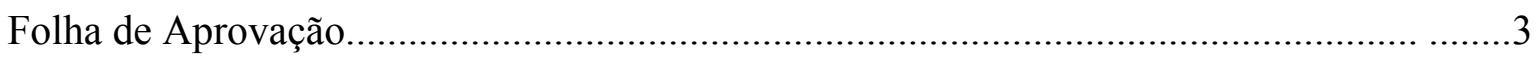

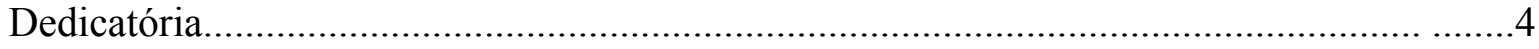

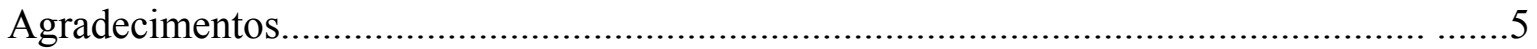

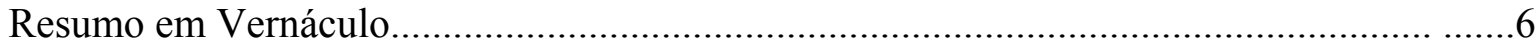

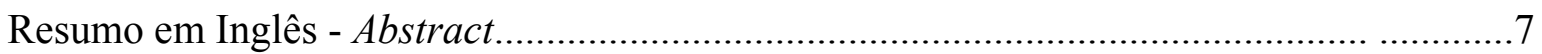

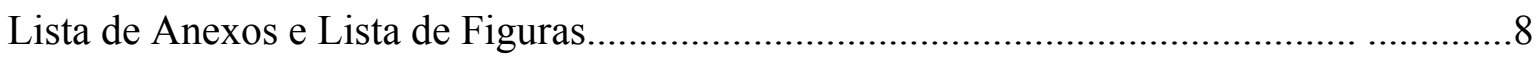

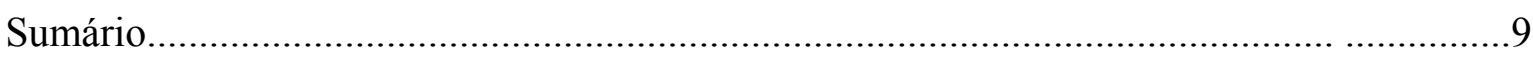

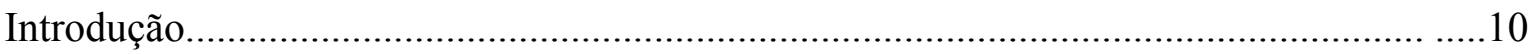

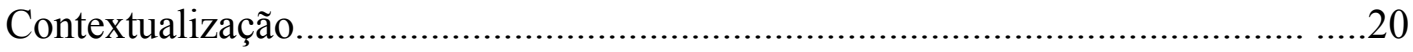

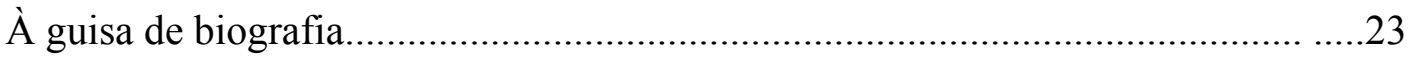

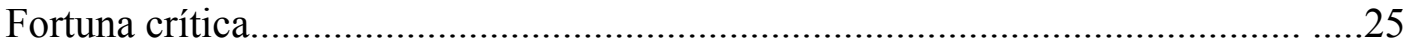

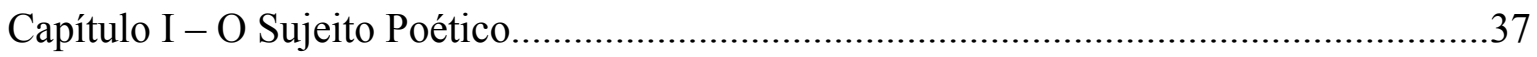

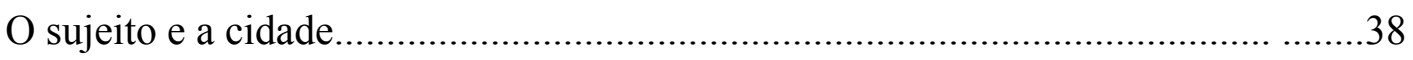

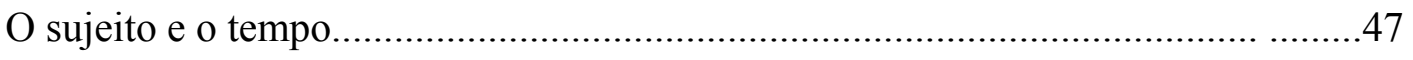

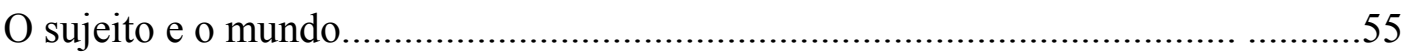

Capítulo II - Espaço Físico e Espaço da Emoção....................................................................67

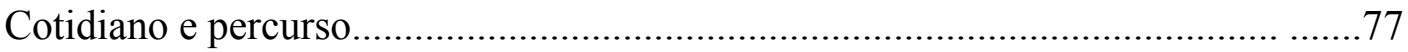

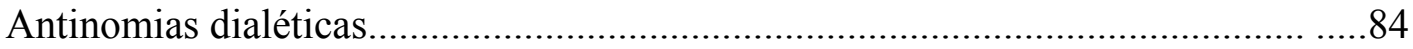

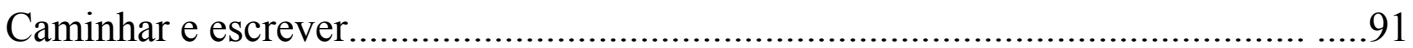

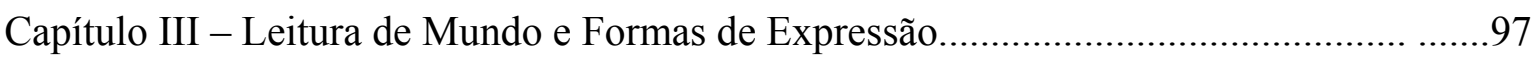

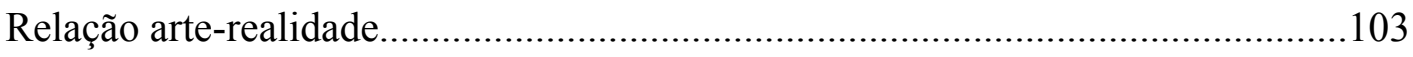

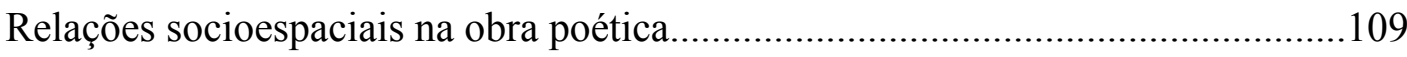

Imagens impressionistas na expressão verbal...................................................111

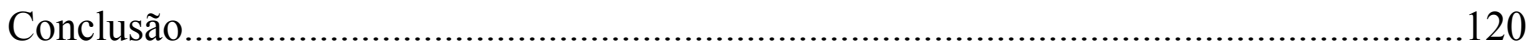

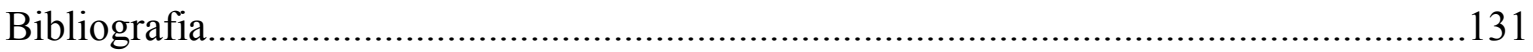

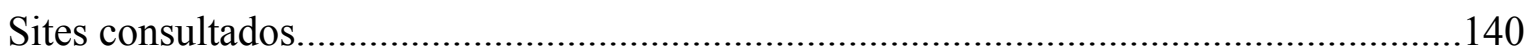

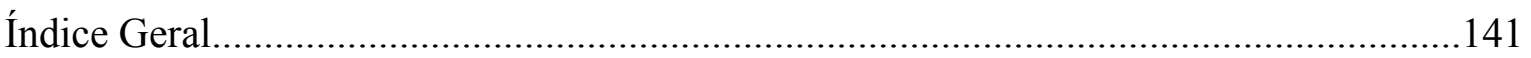

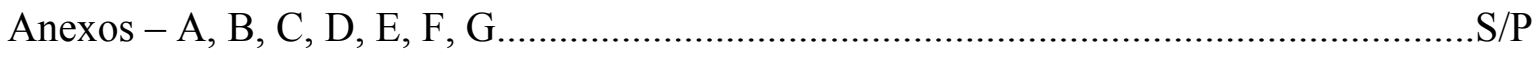

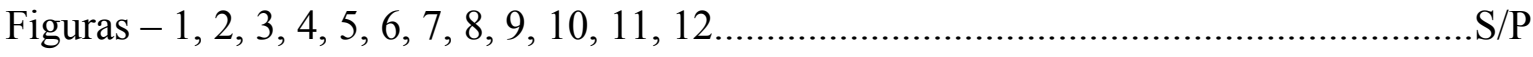



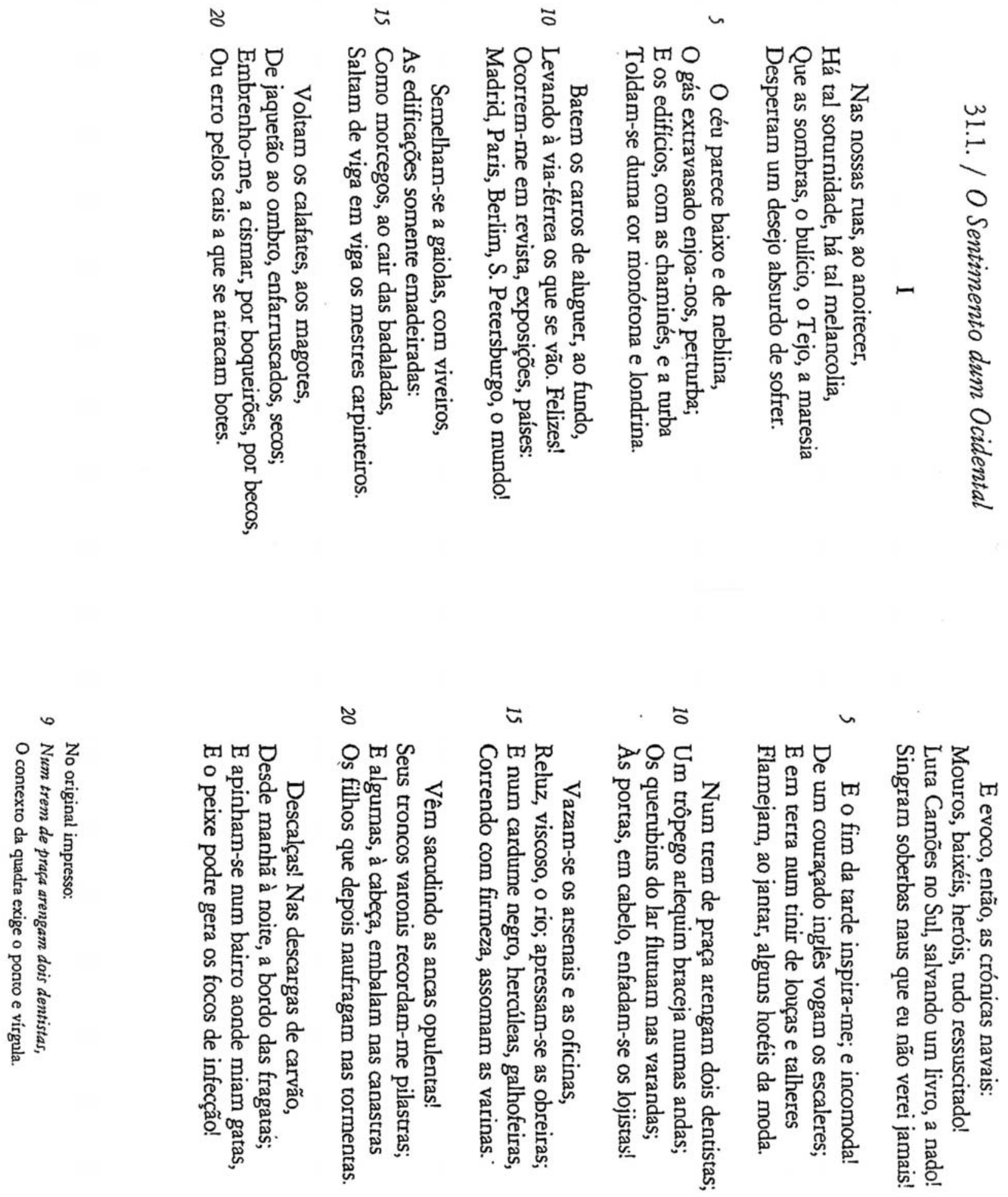

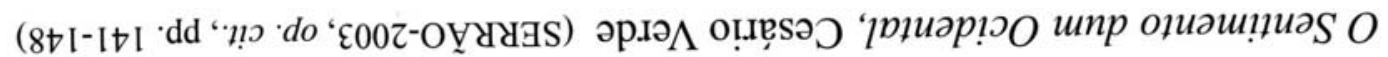



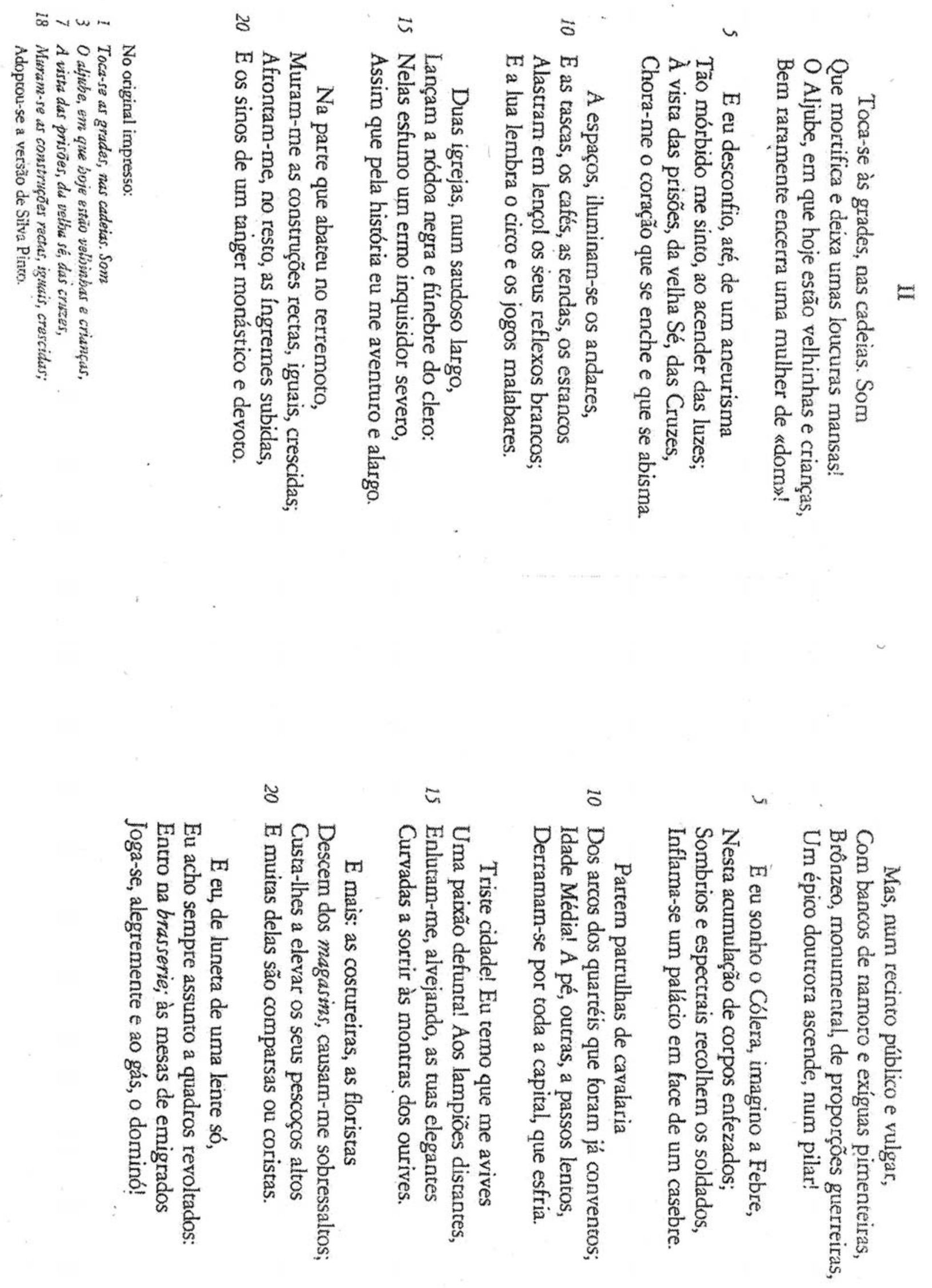
๘

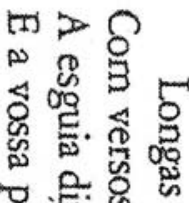

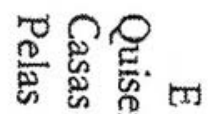

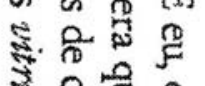

동ํㅛ

is

평

C. 30

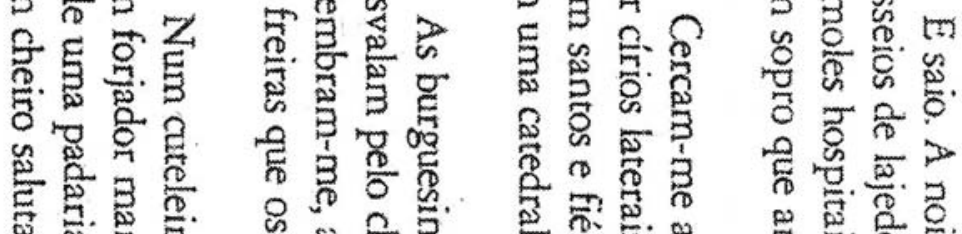

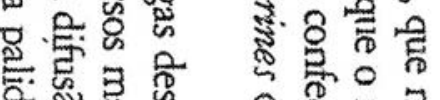

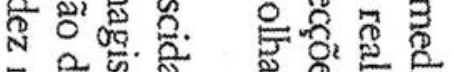

实产

3 赑范

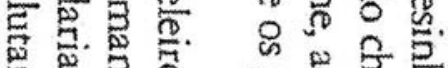

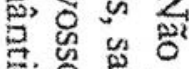

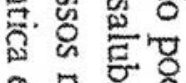

象葛

总营营点.

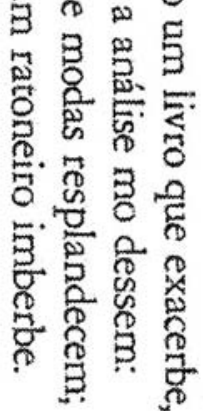

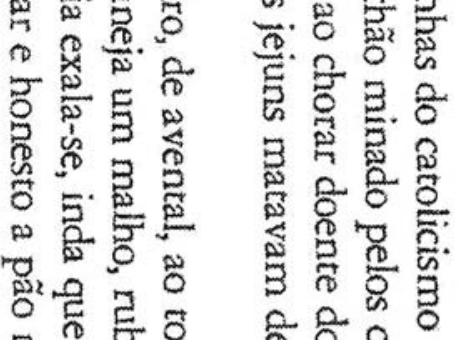

总总总

क유요

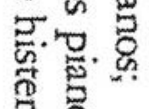

窎.

कि

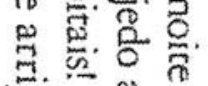

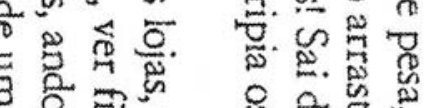

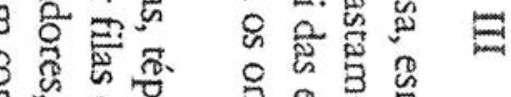

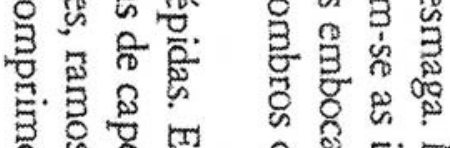

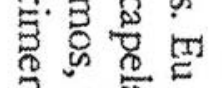

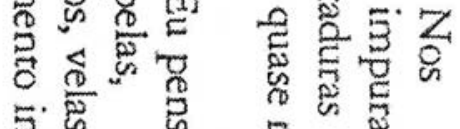

氙

总

ก

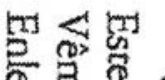

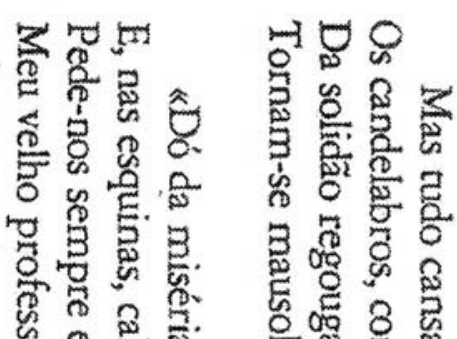

है. कि

总喜吕

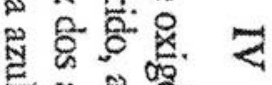

叟

कि

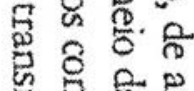

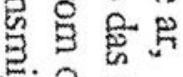

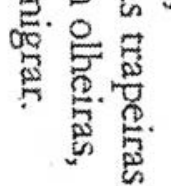

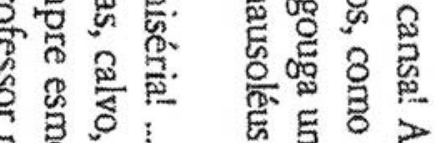

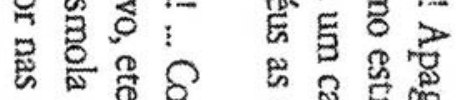

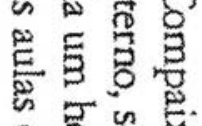

政

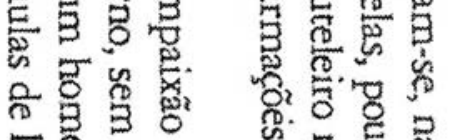

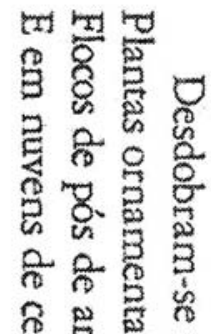

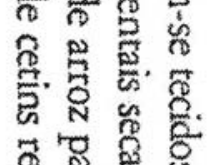

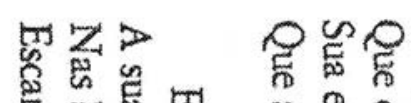

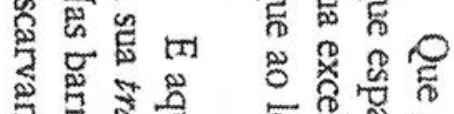

类憵

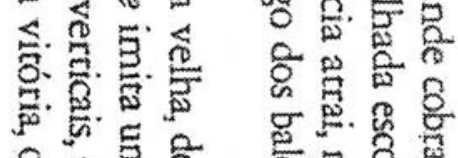

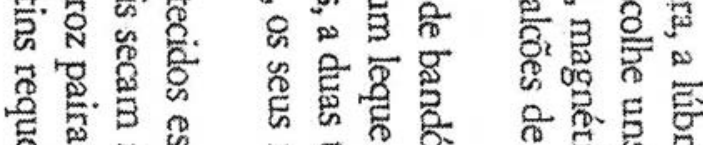

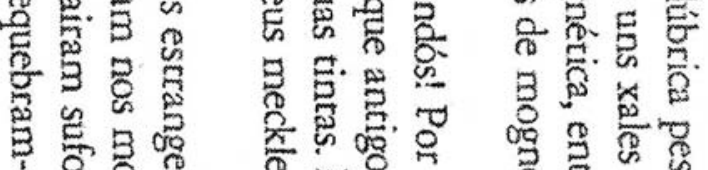

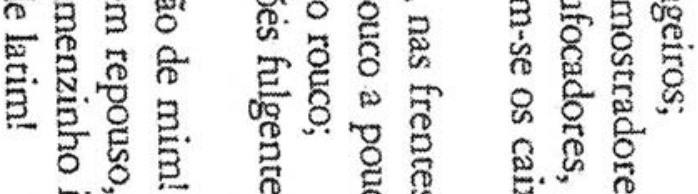

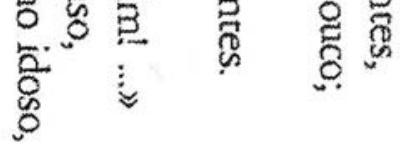

总.

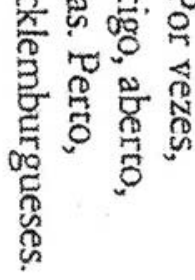

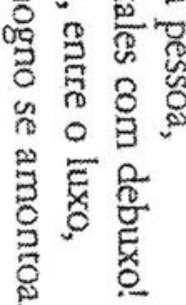



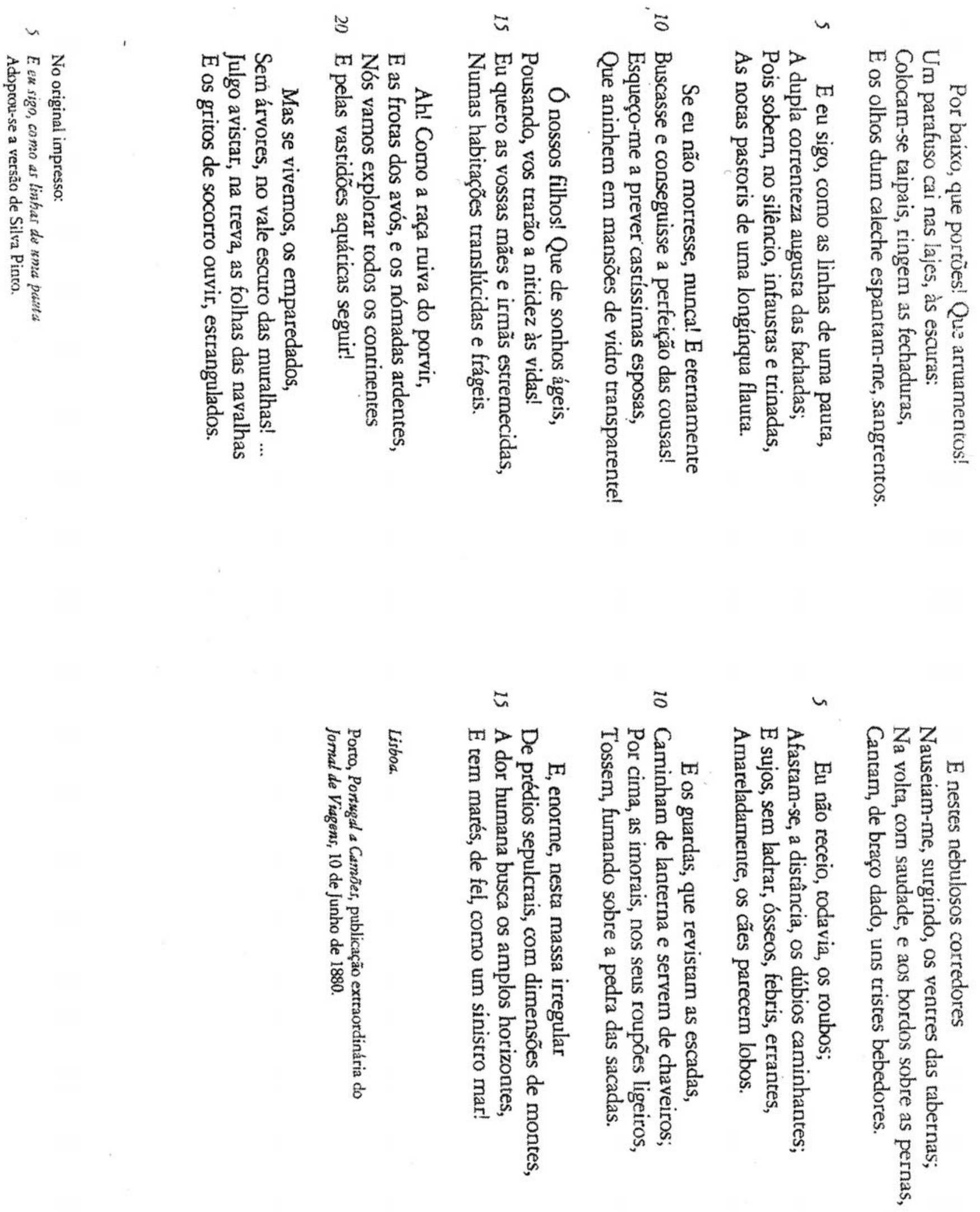


\author{
ANEXO - B \\ EM LISBOA, COM CESÁRIO VERDE *

\begin{abstract}
Nesta cidade, agora me sinto
mais estrangeiro do que os gatos persas;

nesta Lisboa, onde mansos e lisos

os dias passam a ver gaivotas,

e a cor dos jacarandás floridos

se mistura à do Tejo, em flor também,

só o Cesário vem ao meu encontro,

me faz companhia, quando de rua

em rua procuro um rumor distante

de passos ou aves, nem eu sei já bem.

Só ele ajusta a luz feliz dos seus

versos aos olhos ardidos que são

os meus agora; só ele traz a sombra

de um verão muito antigo, com corvetas

lentas ainda no rio, e a música,

o sumo do sol a escorrer da boca,

ó minha infância, meu jardim fechado,

ó meu poeta, talvez fosse contigo

que aprendi a pesar sílaba a sílaba

cada palavra, essas que tu levaste

quase sempre, como poucos mais,

à suprema perfeição da língua.
\end{abstract}

(Eugénio de Andrade)

* ANDRADE, Eugénio de (1986). Em Lisboa, com Cesário Verde, em David MourãoFerreira (dir.), Colóquio/Letras, revista, Lisboa, Fundação Calouste Gulbenkian, no. 93, p. 97. 


\author{
ANEXO - C \\ CESÁRIO VERDE* \\ (Sophia de Mello Breyner Andresen) \\ Quis chamente dizer o mais corrente \\ Com precisão em lúcida esquadria \\ Ser e dizer na justa luz do dia \\ Falar claro falar limpo falar rente \\ Porém nas roucas ruas da cidade \\ A nítida pupila se alucina \\ Cães se miram no vidro da retina \\ E ele vai naufragando como um barco \\ Amou vinhas cearas e campinas \\ Horizontes honestos e lavados \\ Mas bebeu a cidade a longos tragos \\ Deambulou por praças por esquinas \\ Fugiu da peste e da melancolia \\ Livre se quis e não servo dos fados \\ Diurno se quis - porém a luzidia \\ Noite assombrou os olhos dilatados \\ Reflectindo o tremor da luz nas margens \\ Entre ruelas vê-se ao fundo o rio \\ Ele o viu com seus olhos de navio \\ Atentos à surpresa das imagens
}

*ANDRESEN, Sophia de Mello Breyner (1986). Cesário Verde, em David Mourão Ferreira (dir.), Colóquio/Letras, revista, Lisboa, Fundação Calouste Gulbenkian, no. 93, p.94. 


\author{
ANEXO - D \\ IMPROVISO * \\ (Manuel Bandeira) \\ Glória aos poetas de Portugal \\ Glória a D. Dinis. Glória a Gil \\ Vicente. Glória a Camões. Glória \\ a Bocage, a Garett, a João \\ de Deus (mas todos são de Deus, \\ e há um santo; Antero de Quental). \\ Glória a Junqueiro. Glória ao sempre \\ Verde Cesário. Glória a António \\ Nobre. Glória a Eugênio de Castro. \\ A Pessoa e suas heterônimos. \\ A Camilo Pessanha. Glória \\ A tantos mais, a todos mais. \\ - Glória a Teixeira de Pascoais.
}

* BANDEIRA, Manoel. Estrela da Vida Inteira. $12^{a}$. Edição. Rio de Janeiro: José Olímpio Editora, 1986, p, 321. 
ANEXO - E

\section{O SIM CONTRA O SIM}

(a Felix de Athayde)

(João Cabral de Melo Neto) *

Cesário Verde usava a tinta

de forma singular

não para colorir

apesar na cor que nele há.

talvez que nem usasse tinta,

somente água clara,

aquela água de vidro

que se vê percorrer a Arcádia.

Certo, não escrevia com ela,

ou escrevia lavando:

revelava, enxaguava

seu mundo em Sábado de banho.

Assim chegou aos tons opostos

das maçãs que contou:

rubras dentro da cesta

de que no rosto as tem sem cor.

NETO, João Cabral. (Recife PE 1920 - Rio de janeiro RJ 1999).

Poesia Completa. Lisboa: Imprensa Nacional/Casa da Moeda, 1986. 


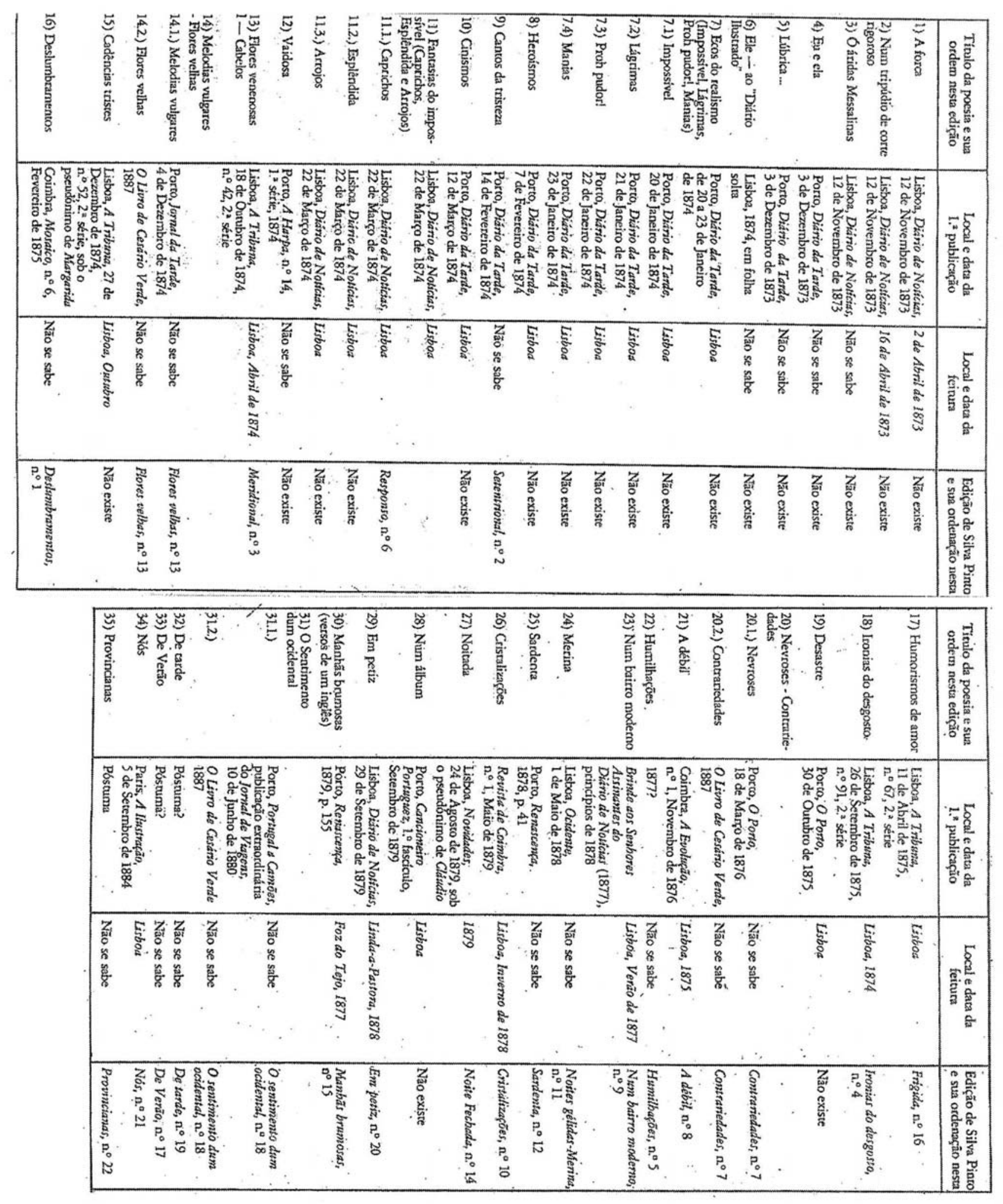




\section{ANEXO - G \\ FICÇÕES DE INTERLÚDIO *}

III

Ao entardecer, debruçado pela janela,

E sabendo de soslaio que há campos em frente,

Leio até me arderem os olhos

O livro de Cesário Verde

Que pena tenho dele! Ele era um camponês

Que andava preso em liberdade pela cidade.

Mas o modo como reparava nas ruas,

E a maneira como dava pelas cousas,

$\dot{E}$ de quem olha para árvores, e de quem desce os olhos pela

[estada por onde vai andando

E anda a reparar nas flores que há pelos campos...

Por isso ele tinha aquela grande tristeza

Que ele nunca disse bem que tinha,

Mas andava na cidade como quem anda no campo

E triste como esmagar flores em livros

E por plantas em jarros...

PESSOA, Fernando. Ficções de Interlúdio/1: Poemas Completos de Alberto Caeiro, $6^{\mathrm{a}}$ Ed.

RJ: Nova Fronteira, 1980, p. 140. 
FIGURA - 1

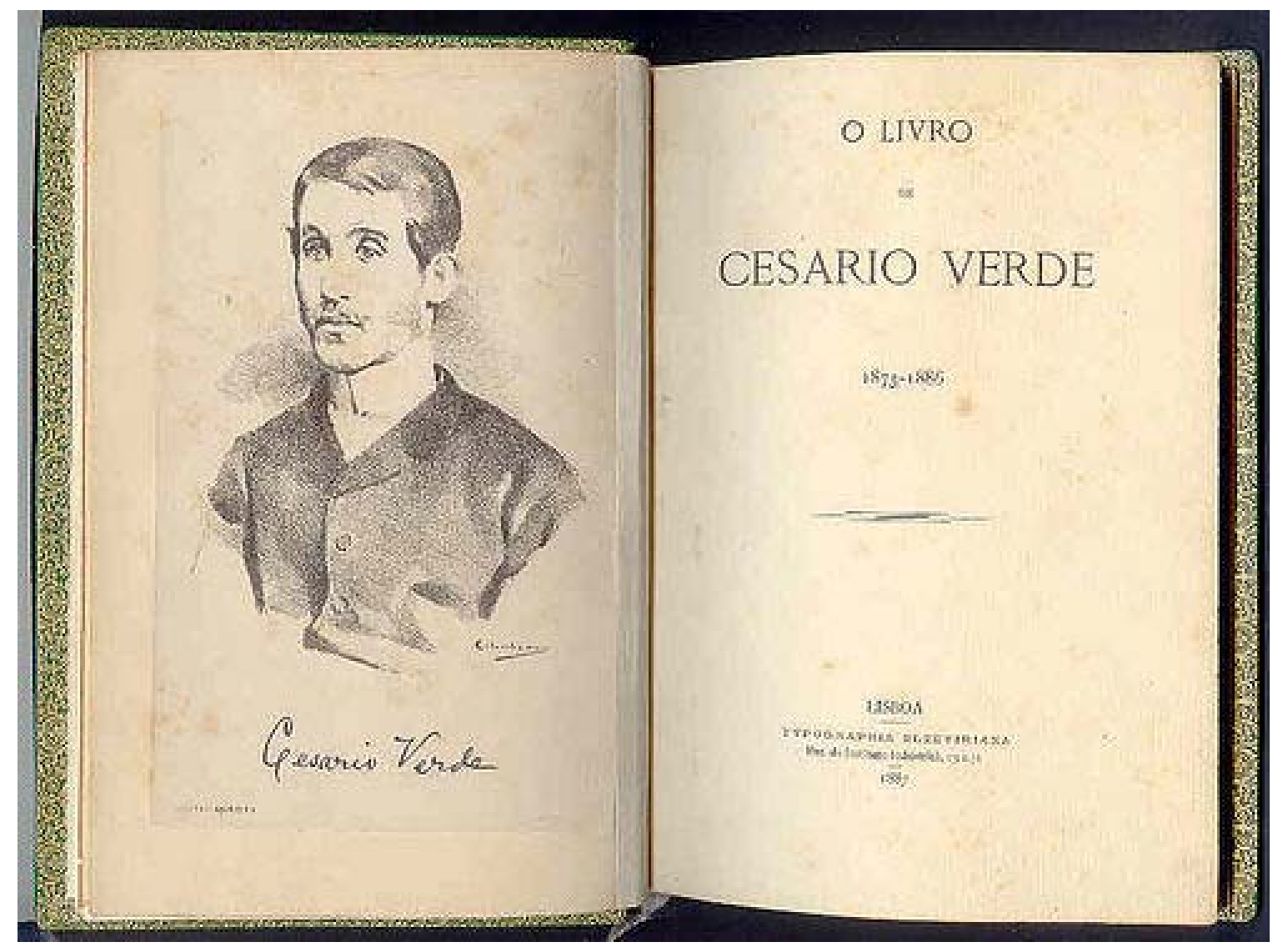

Reprodução do "Retrato de Cesário Verde", pintado por Columbano Bordalo Pinheiro. www.e-cultura.pt/images; consultado em 2 de Julho de 2008. 
FIGURA - 2

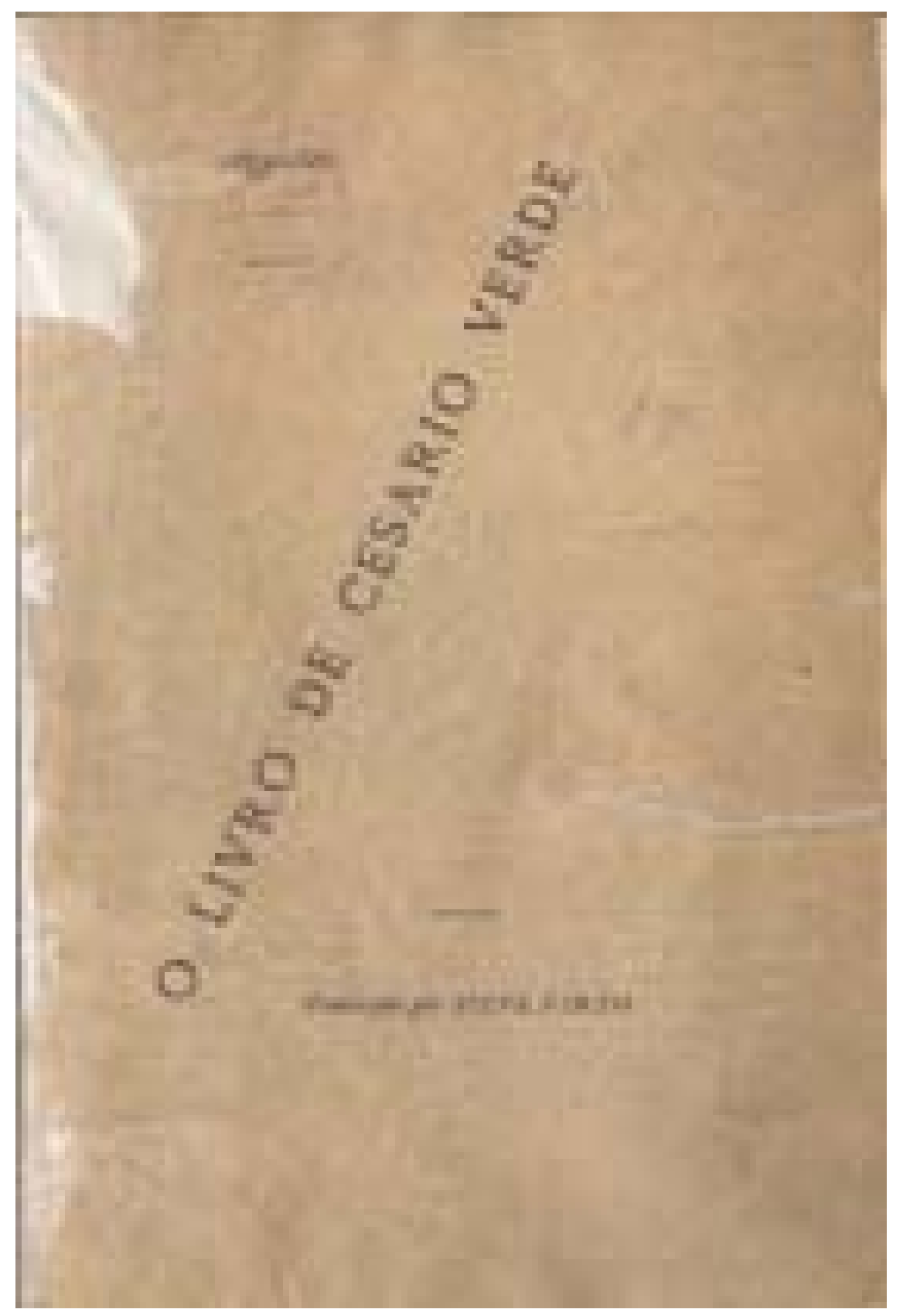

Reprodução da capa de “O Livro de Cesário Verde”, editado por Silva Pinto - 1887. www.e-cultura.pt/images; consultado em 2 de julho de 2008. 
FIGURA - 3

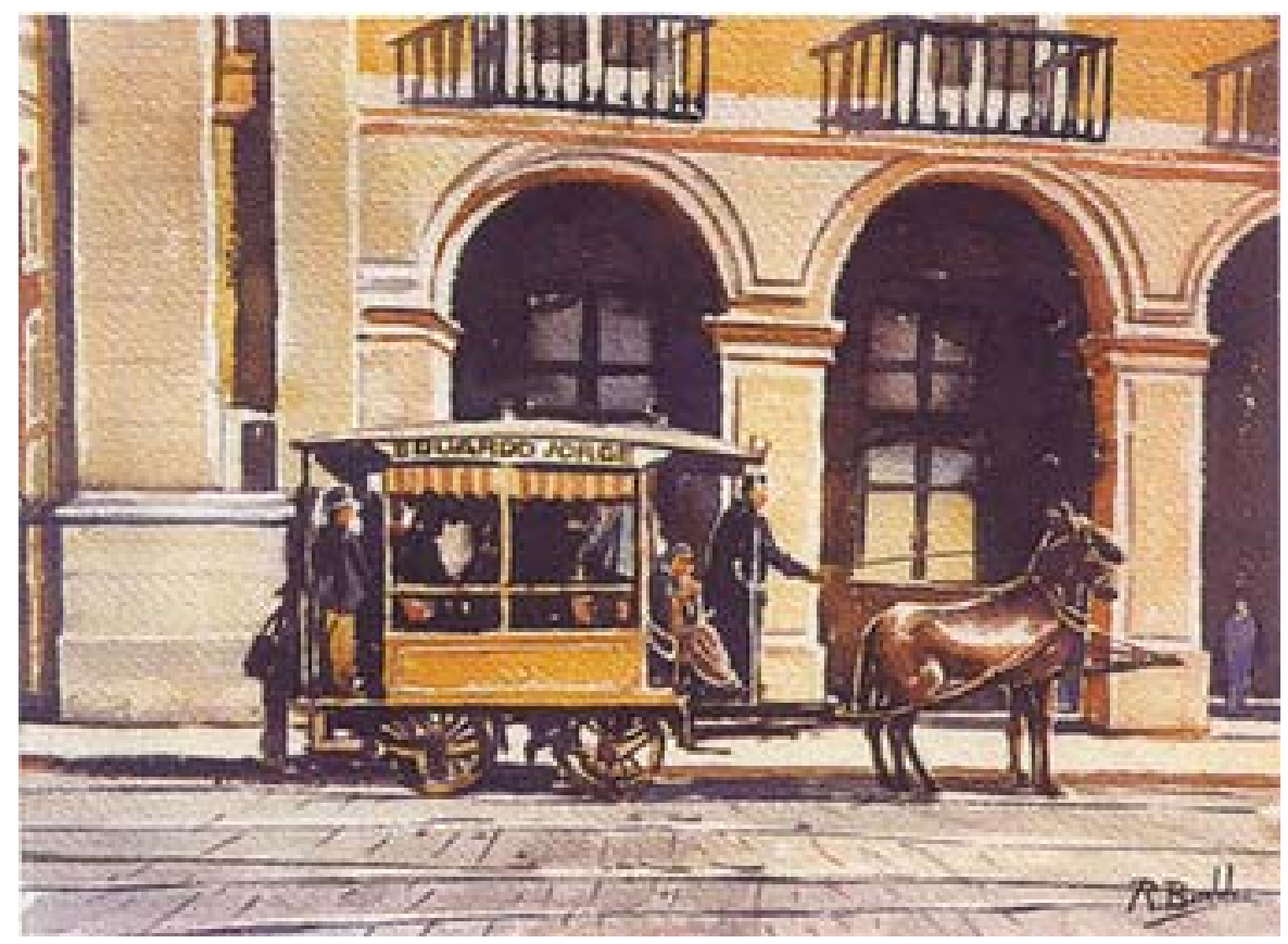

Reprodução da pintura "O Chora" - Óleo sobre tela, Rafael Bordalo Pinheiro. www.e-cultura.pt/images; consultado em 21 de setembro de 2008. 


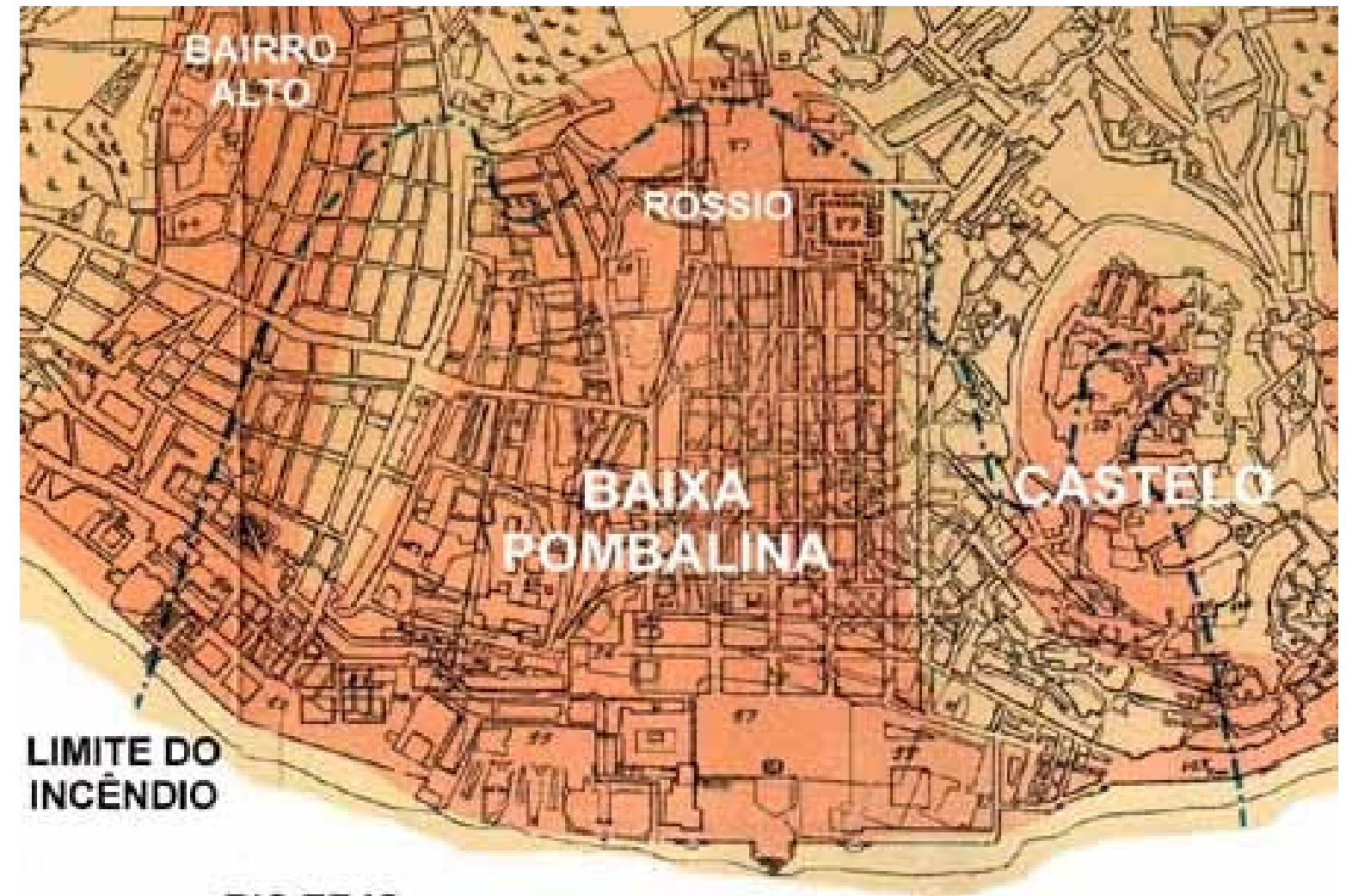

RIO TEJO

Reprodução do Mapa de Lisboa, limite do incêndio de 1755 - Manuel da Maia. http//webcarta.net.cart/mapas; consultado em 7 de setembro de 2008 
FIGURA - 5

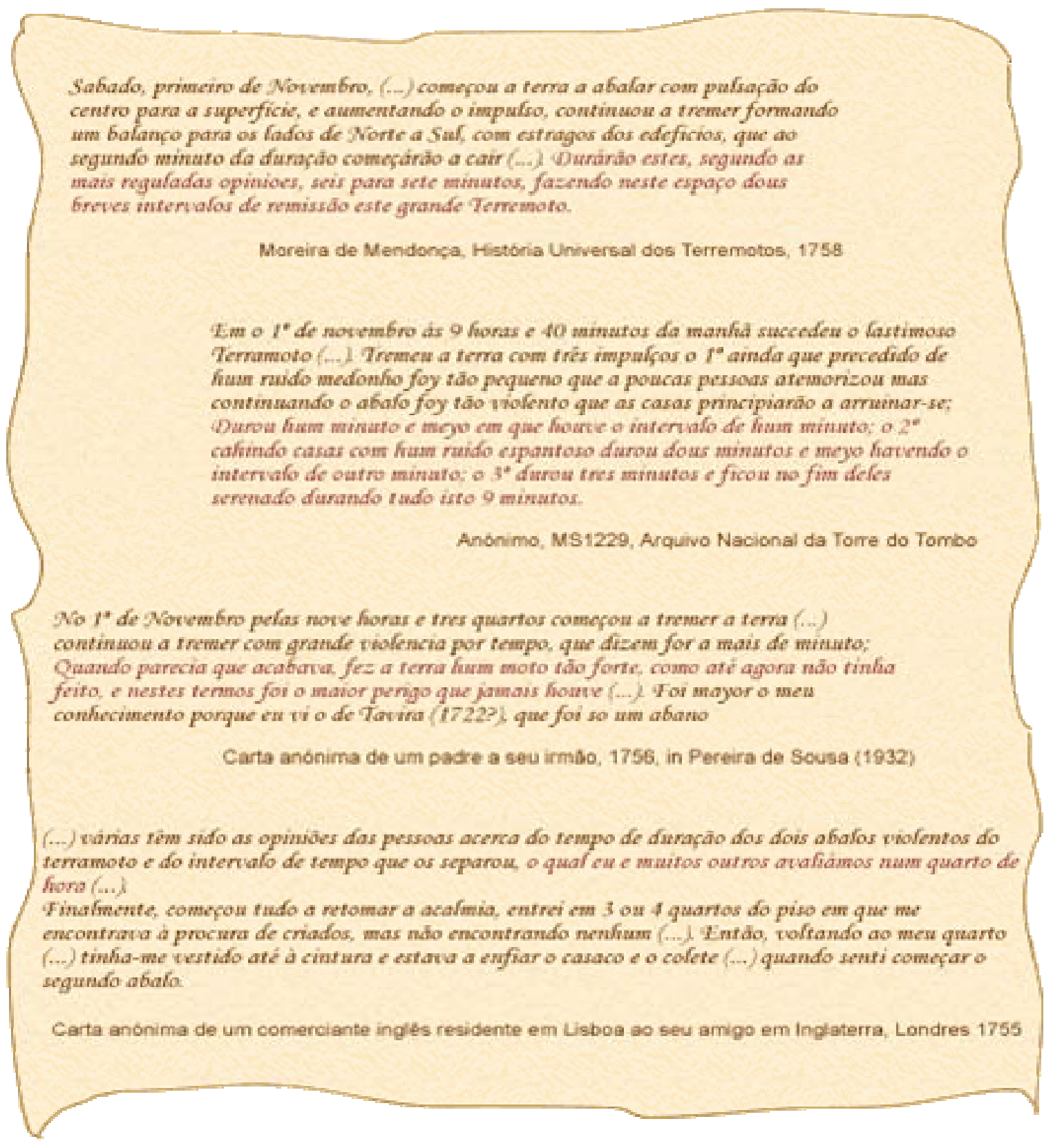

Reprodução de Textos diversos sobre o terremoto de Lisboa de 1755. webserver.com.lisboa.pt; consultado em 8 de dezembro de 2008. 
FIGURA - 6

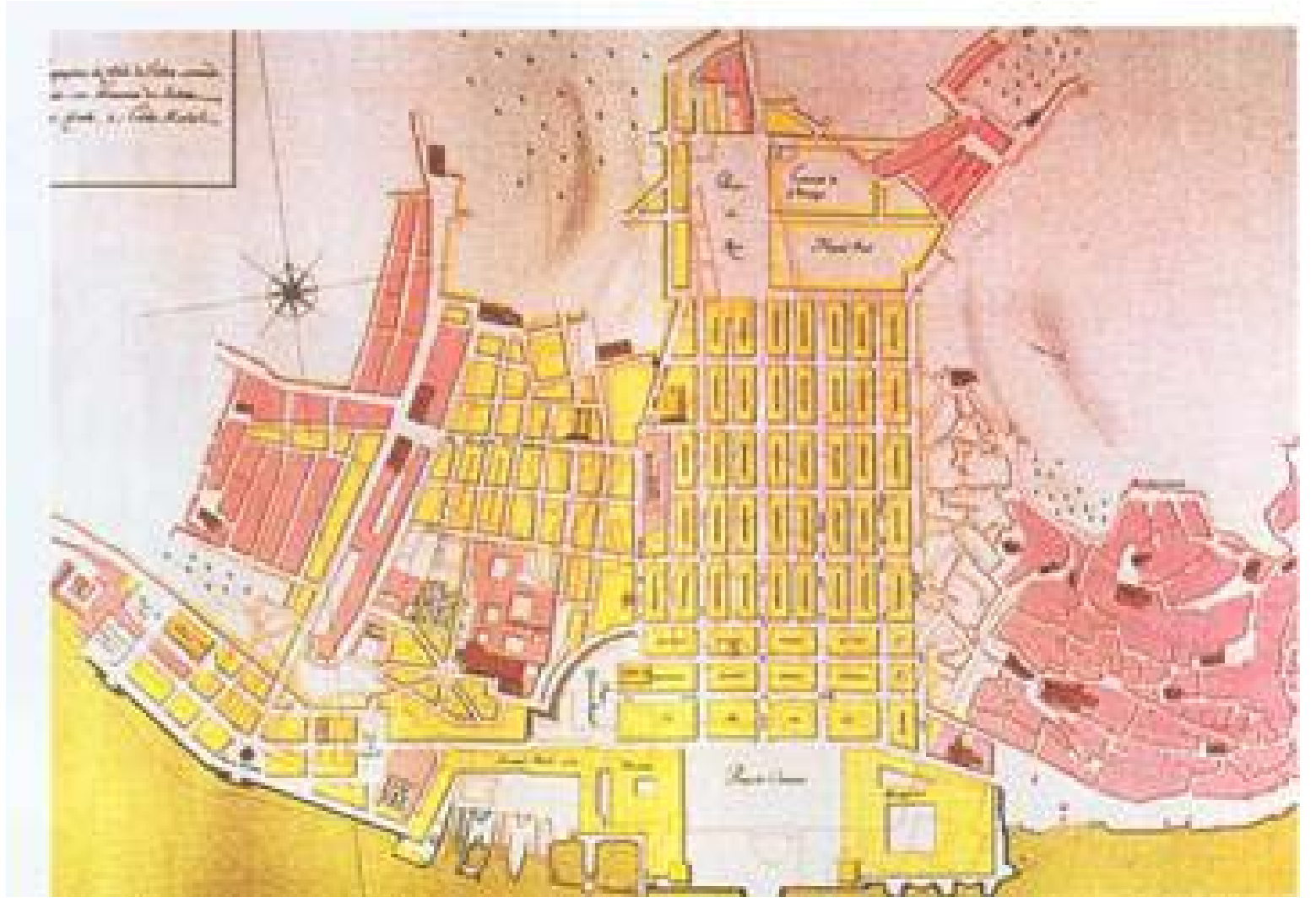

Reprodução do Plano de Reconstrução de Lisboa, 1756 - Eugénio dos Santos Carvalho webserver.com.lisboa.pt; consultado em 7 de setembro de 2008. 
FIGURA - 7

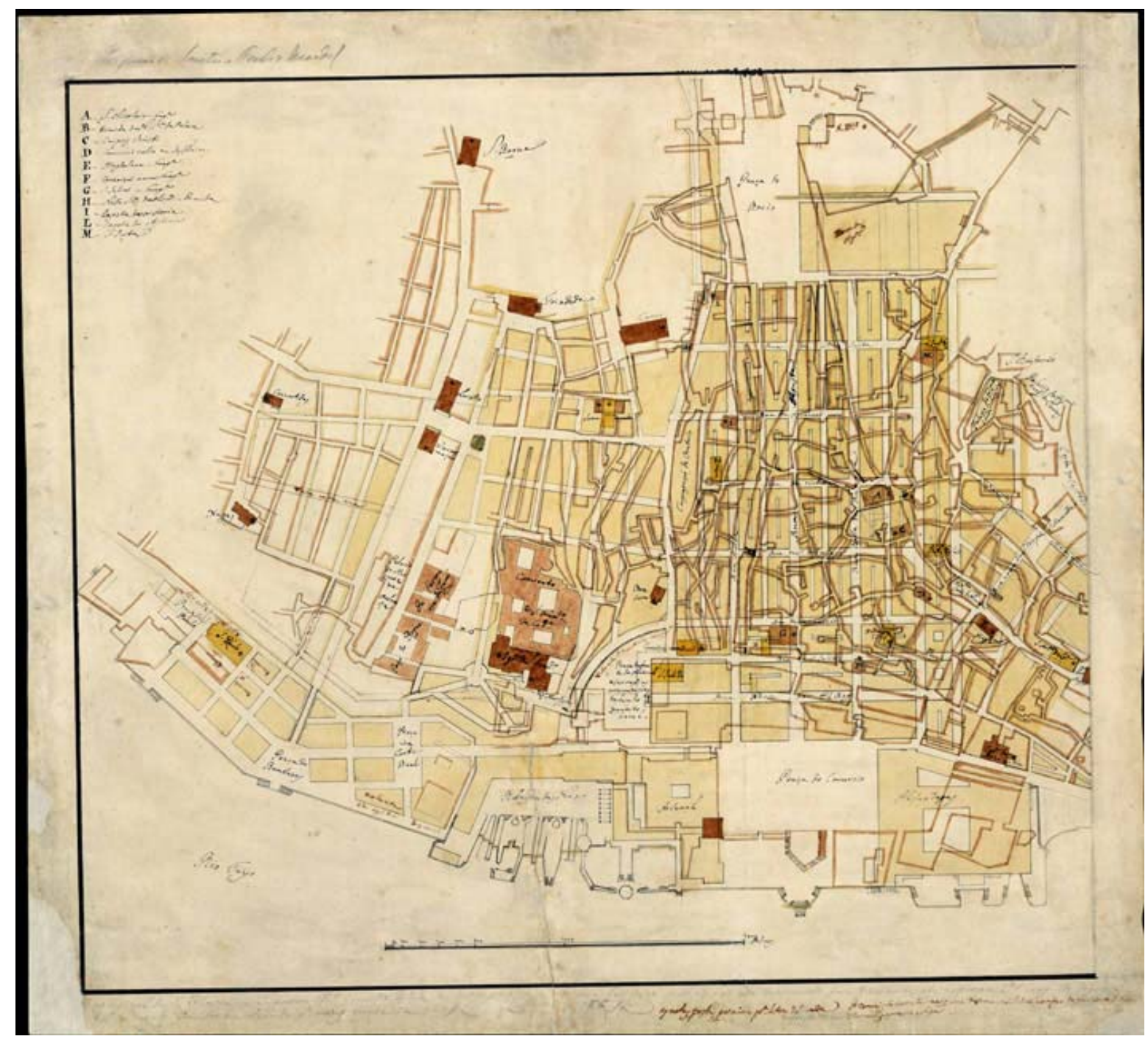

Reprodução da Planta do centro da cidade de Lisboa antes do terremoto de 1755 e com os projetos dos novos arruamentos. Eugénio dos Santos Carvalho e Carlos Mardel (?) (circa 1760) CA354 - Instituto Geográfico Português - www.igeo.pt/images; consultado em 7 de setembro de 2008. 
FIGURA - 8

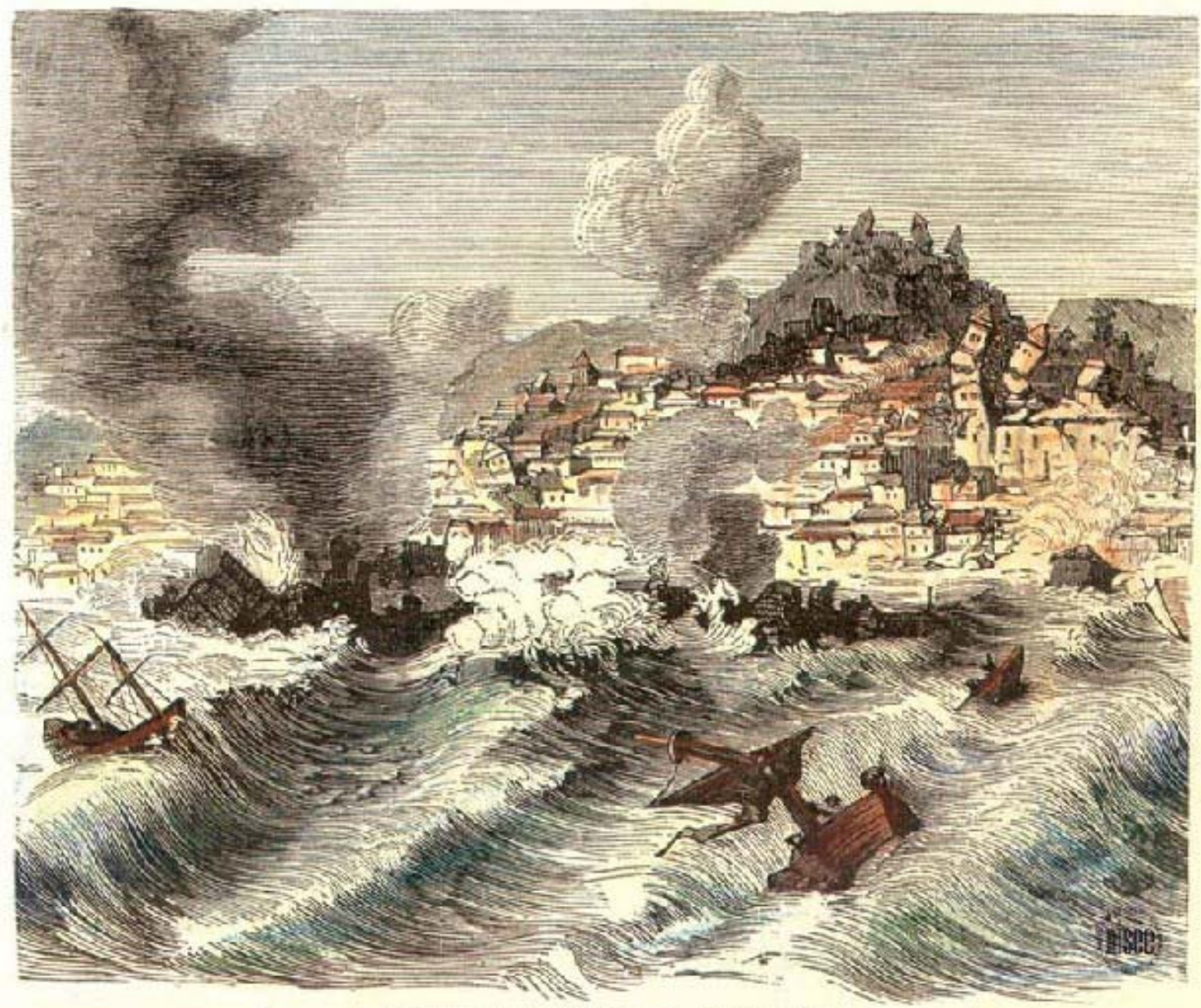

Grobeben von 2ifiabont, 1. Rotbr. 1755

Reprodução de pintura do "Maremoto de Lisboa de $1^{\circ}$. de. Novembro de 1755" . Autor desconhecido. www.vanillanist.com; bloguehistorico.wordpress; consultado em 21 de setembro de 2008. 
FIGURA - 9

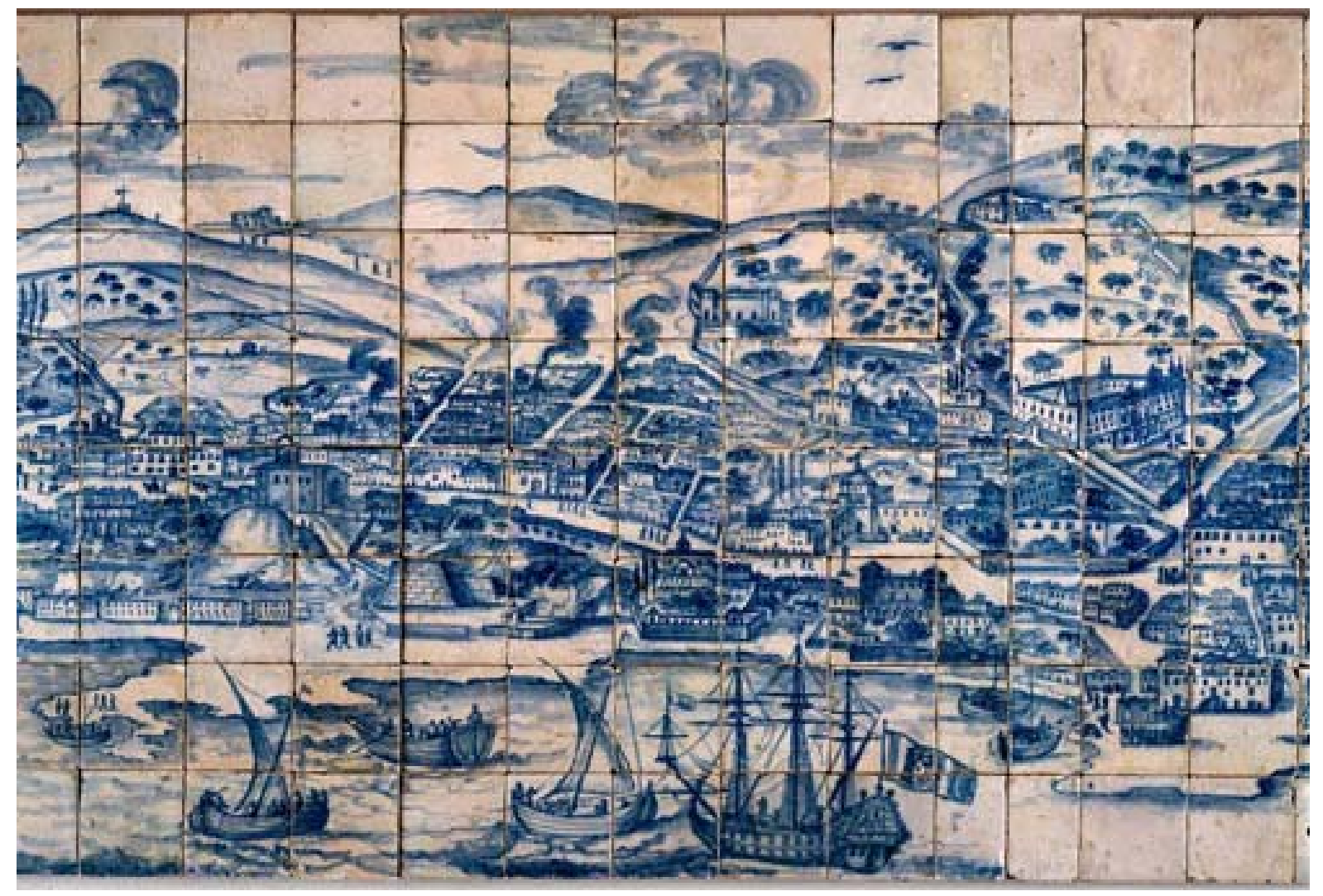

Reprodução do Painel de Azulejos, Lisboa antes do terremoto de 1755 - Autor desconhecido. www.e-cultura.pt/images; consultado em 2 de julho de 2008. 
FIGURA - 10

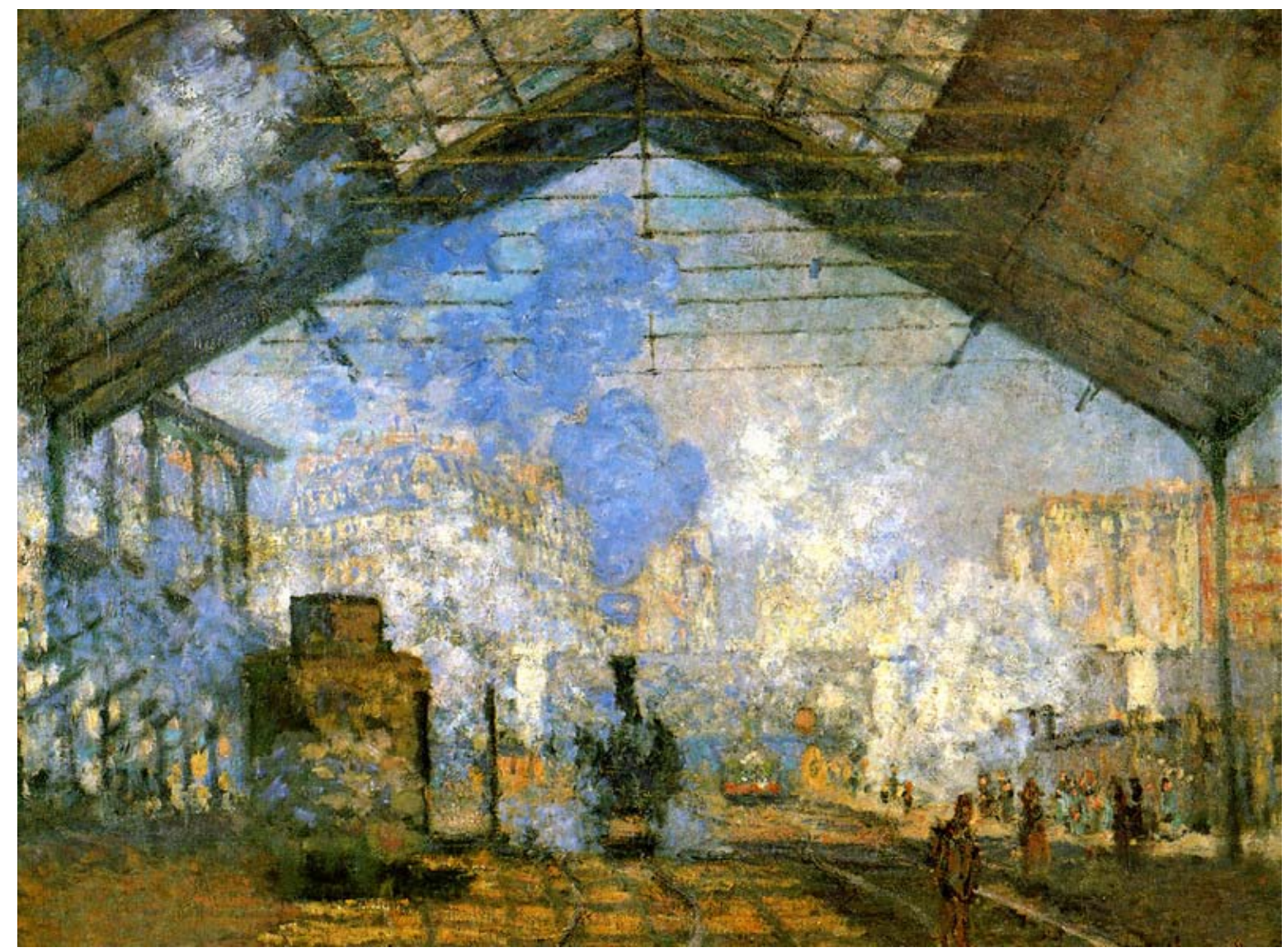

Reprodução da pintura "Gare de Saint Lazare" (1876) - Claude Monet - Musèe d' Orsay, Paris. www.museedorsay.paris; consultado em 21 de setembro de 2008. 
FIGURA - 11

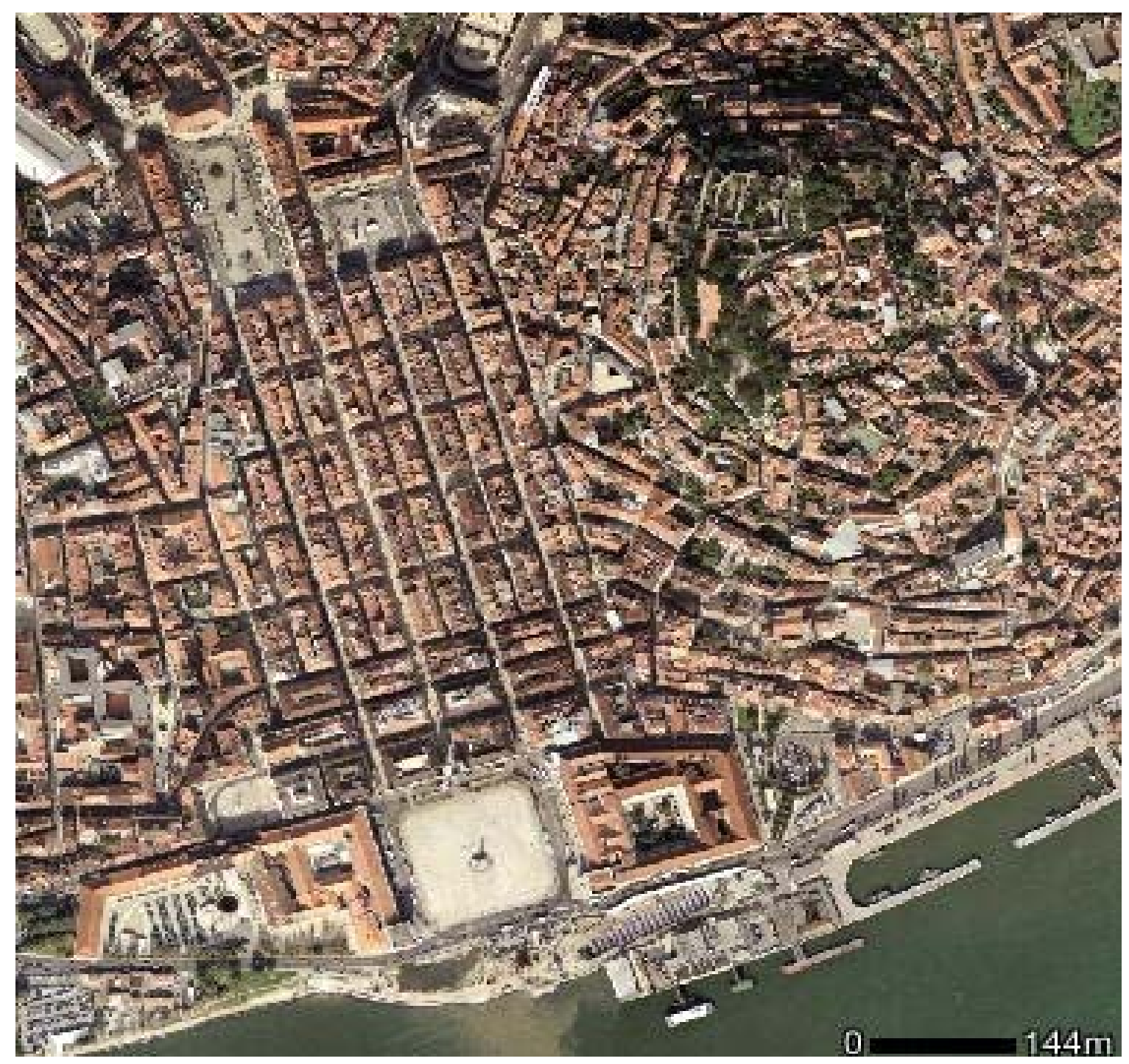

Reprodução de Foto aérea da Lisboa - www.skyserapercity.com; consultado em 7 de setembro de 2008. 


\section{FIGURA - 12}

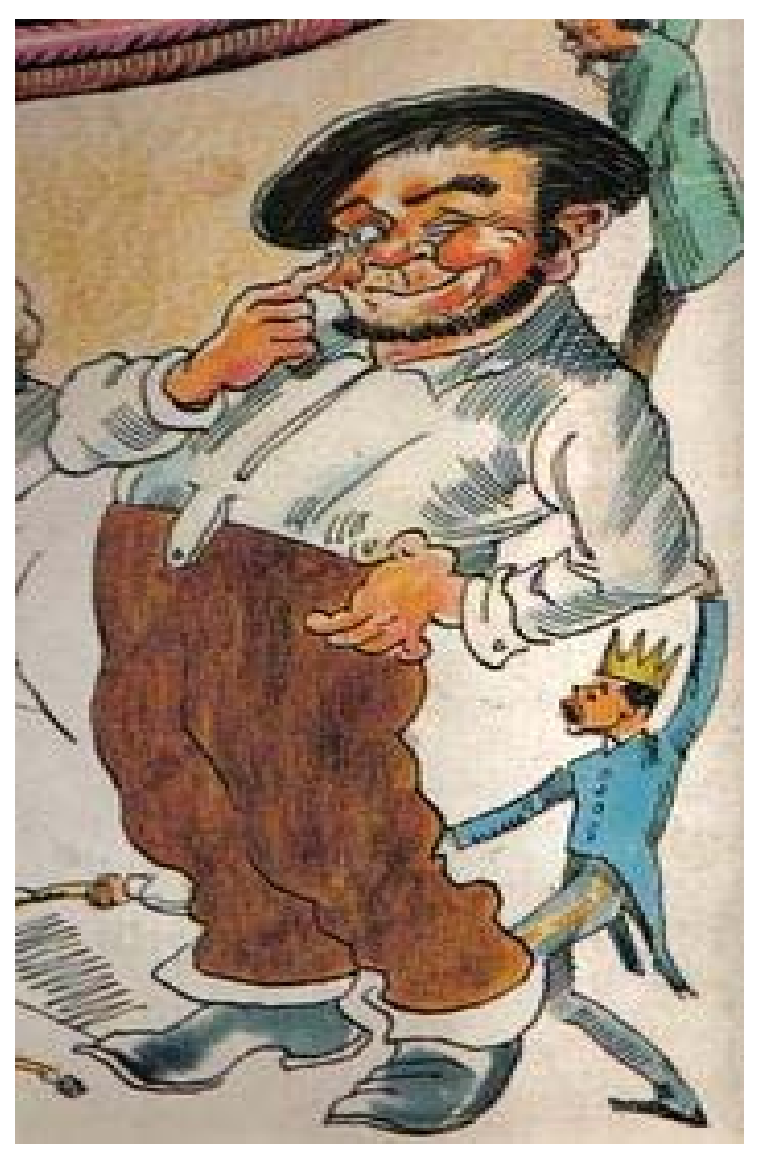

Zé Povinho (1875), Bordalo Pinheiro.

www.museubordalo pinheiro.pt - consultado em 23.02.2009 